UNIVERSIDADE DE SÃO PAULO

ESCOLA DE ENGENHARIA DE SÃO CARLOS

\title{
MÁRCIO HENRIQUE FERREIRA
}

Análise da vida em fadiga termomecânica de ferros fundidos cinzento e vermicular

São Carlos 



\section{MÁRCIO HENRIQUE FERREIRA}

Análise da vida em fadiga termomecânica de ferros fundidos cinzento e vermicular

Versão Corrigida

Dissertação apresentada ao programa de Pós-Graduação em Ciência e Engenharia de Materiais da Universidade de São Paulo, para obtenção do título de Mestre em Ciências.

Área de concentração: Desenvolvimento, Caracterização e Aplicação de Materiais.

Orientador: Prof. Dr. Cassius Olivio Figueiredo Terra Ruchert 
AUTORIZO A REPRODUÇÃo E DIVULGAÇÃo TOTAL OU PARCIAL DESTE TRABALHO, POR QUALQUER MEIO CONVENCIONAL OU ELETRÔNICO, PARA FINS DE ESTUDO E PESQUISA, DESDE QUE CITADA A FONTE.

Ferreira, Márcio Henrique

F382a

Análise da vida em fadiga termomecânica de ferros fundidos cinzento e vermicular / Márcio Henrique

Ferreira; orientador Cassius Olivio Figueiredo Terra Ruchert. São Carlos, 2017.

Dissertação (Mestrado) - Programa de Pós-Graduação em Ciência e Engenharia de Materiais e Área de Concentração em Desenvolvimento, Caracterizaçào e Aplicação de Materiais -- Escola de Engenharia de São Carlos da Universidade de São Paulo, 2017.

1. Ferro fundido cinzento. 2. ferro fundido vermicular. 3. fadiga termomecănica. 4. ciclo térmico. 5. morfologia. I. Título. 


\section{FOLHA DE JULGAMENTO}

Candidato: Tecnólogo MÁRCIO HENRIQUE FERREIRA.

Título da dissertação: "Análise da vida em fadiga termomecânica de ferros fundidos cinzento e vermicular".

Data da defesa: 11/05/2017.

Comissāo Julgadora:

Prof. Associado Cassius Olivio Figueiredo Terra Ruchert (Orientador)

(Escola de Engenharia de Lorena/EEL)

Prof. Dr. Wilson Luiz Guesse

(Universidade do Estado de Santa Catarina/UDESC)

Prof. Dr. Mauricio Angeloni

(FATEC Sertãozinho)
Resultado:
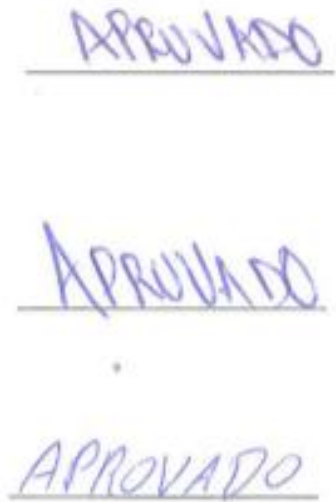

Coordenador do Programa de Pós-Graduação em Ciências e Engenharia de Materiais:

Prof. Associado Antonio José Felix de Carvalho

Presidente da Comissão de Pós-Graduação:

Prof. Associado Luís Fernando Costa Alberto 

Primeiramente a Deus,

Ao meu pai Josué,

À minha mãe Zelinda, por todo amor, carinho e sacrifício,

Aos meus Irmãos, por estarem sempre ao meu lado. 



\section{AGRADECIMENTOS}

Agradeço primeiramente a Deus, que sempre esteve em minha vida.

À minha mãe Zelinda Previato Ferreira e meu pai Josué Luiz Ferreira que sempre me apoiaram e acreditaram em mim.

Ao Prof. Dr. Cassius Olivio Figueiredo Terra Ruchert por sua valiosa orientação, confiança e paciência.

Ao Prof. Dr. Waldek Wlademir Bosse Filho, pela parceria e objetividade em sua orientação.

Ao Prof. Dr. Wilson Luiz Guesser, pela enorme contribuição de seu conhecimento para a realização deste trabalho.

Aos professores Dr. Mauricio Angeloni, Dr. Omar Maluf, Dr. Alessandro Fraga Farah, pelo apoio e contribuição nesta pesquisa.

Ao meu irmão Marco e minha cunhada Jessica, que me ajudou muito na execução deste trabalho.

A todos os professores do SMM e externos que, de alguma forma, contribuíram para minha formação.

Aos técnicos do laboratório SMM-EESC-USP, em especial ao Wagner, Pedro, Silvano, Douglas, Alberto e João pela ajuda na realização deste trabalho experimental;

Ao secretário de Pós-graduação Victor Luiz Barioto e as secretárias do Departamento de Engenharia de Materiais EESC-USP Priscila e Ana, pela amizade e por sempre me ajudarem em tudo que precisei.

Aos amigos do grupo de NEMAF pelo companheirismo, de todos os dias.

Aos meus amigos do Departamento de Engenharia de Materiais EESC-USP: Ronald Morales, Marta Gama, Fernando Artefacto, Carla Isabel, Marcos Vinicícius, Elielson Santos, Raimundo Amorim, Júlio Cesar, Luís Bonazzi, Deliane Cabral, Guálter Pereira, Jakeline Ferreira, Wesley Takaessu e todos os demais colegas do Departamento, no qual tive o prazer de aprender e conviver todos os dias. Levarei essas amizades para a vida toda.

Ao programa de Pós-Graduação em Ciência e Engenharia de Materiais da USP- São Carlos pela oportunidade de realização do curso de Mestrado, pela infraestrutura e formação acadêmica.

A CAPES pelo suporte financeiro, na forma de bolsa de estudos, para o desenvolvimento desse trabalho. 
À empresa TUPY S.A., pelo fornecimento dos corpos de prova utilizados nos ensaios e oportunidade de usar o acervo bibliográfico.

Enfim, a todos que de uma forma ou outra estiveram envolvidos na realização desde trabalho e na participação desta etapa da minha vida, os meus sinceros agradecimentos. 
"Por vezes sentimos que aquilo que fazemos não é senão uma gota de água no mar. Mas o mar seria menor se lhe faltasse uma gota.”

(Madre Teresa de Calcutá) 



\section{RESUMO}

FERREIRA, M. H. Análise da vida em fadiga termomecânica de ferros fundidos cinzento e vermicular, 98p. Dissertação (Mestrado) - Escola de Engenharia de São Carlos, Universidade de São Paulo, São Carlos, 2017.

Motores de combustão interna são submetidos a carregamentos térmicos e mecânicos que podem resultar em trincas devido ao fenômeno de fadiga termomecânica, FTM. Ferros fundidos tem sido uma escolha comum para a fabricação de blocos e cabeçotes de motores a diesel. Para melhorar o desempenho dos motores é importante ter uma compreensão clara do comportamento em FTM destes materiais, permitindo a previsão de vida, melhorando as propriedades de novas ligas, bem como aumentar a confiabilidade desses componentes. Assim, este projeto teve como objetivo avaliar a vida em FTM de dois tipos de ferro fundido usado na fabricação de motores de combustão interna. Os testes foram realizados em um sistema de teste mecânico MTS 810 , em controle de deformação com $100 \%$ de restrição $(\Delta \varepsilon=$ 0), utilizando um forno de indução de alta frequência para aquecimento e um dispositivo de resfriamento (condução e convecção), registrando as tensões e número de ciclos. Os ciclos térmicos aplicados simulam as condições de trabalho, em modo acelerado, de um motor de combustão interna, aplicando um ciclo térmico em forma de uma onda trapezoidal, com temperaturas mínimas e máximas de 50 e $420{ }^{\circ} \mathrm{C}$, respectivamente e um tempo de permanência de $180 \mathrm{~s}$ na temperatura máxima, e tempo de ciclo total de $300 \mathrm{~s}$. Os resultados mostram que o ferro fundido vermicular apresenta uma vida em FTM maior que o ferro fundido cinzento porque a morfologia dos veios de grafita que atuam como concentradores de tensão no ferro fundido cinzento reduz acentuadamente a sua rigidez durante a tensão trativa, causando a formação de micro trincas em um número menor de ciclos.

Palavras-chave: Ferro fundido cinzento, ferro fundido vermicular, fadiga termomecânica, ciclo térmico, morfologia. 



\begin{abstract}
FERREIRA, M. H. Thermomechanical Fatigue Life of Grey and Compact Cast Irons, 98p. Dissertação (Mestrado) - Escola de Engenharia de São Carlos, Universidade de São Paulo, São Carlos, 2017.

Internal combustion engines are subjected to thermal and mechanical loads that may result in cracks due to thermomechanical fatigue phenomenon, TMF. Cast irons have been a common choice for the manufacture of blocks and cylinder heads of diesel engines. To improve the engines performance it is important to have a clear understanding of the FTM behavior of these materials, enabling life prediction, improving the properties of new alloys, as well as increase the reliability of these components. Thus, this project aims to evaluate the TMF life of two types of cast iron used in the manufacture of internal combustion engines. The tests were performed on a MTS 810 mechanical testing system, in displacement control and $100 \%$ restriction $(\Delta \varepsilon=0)$, using a high-frequency induction furnace for heating and a cooling device (conduction and convection), recording the stresses, strains and number of cycles. The thermal cycles applied have heating and cooling cycles that simulate the work conditions, in accelerated mode, of an internal combustion engine, applying an trapezoidal wave shape, with minimum and maximum temperatures of 50 and $420^{\circ} \mathrm{C}$ respectively, and a $180 \mathrm{~s}$ dwell time at maximum temperature, and total cycle time of $300 \mathrm{~s}$. The results showed that compact cast iron presents TMF life larger than the gray cast iron because the morphology of graphite flakes in the gray cast iron reduces markedly their rigidity during the traction portion of the tensile part of the cycle, causing the defects formation at smaller number of cycles. The thermomechanical behavior of these two types of cast irons are discussed in detail.
\end{abstract}

Keywords: Grey cast iron, compact cast iron, thermomechanical fatigue, thermal cycles. 



\section{LISTA DE FIGURAS}

Figura 1: Locais críticos de válvula e cabeças de cilindro sob condições de FTM, (a) trincas macroscópicas em cabeças de cilindro e (b) distribuição de temperatura em locais críticos...28

Figura 2: Diagrama ferro carbono.

Figura 3: Diagrama indicando as estruturas dos ferros fundidos resultantes com a variação de silício.

Figura 4: Desenho esquemático mostrando a solidificação de uma liga hipoeutética, onde linhas sólidas: sistema estável (formação de grafita) e, linhas tracejadas: metaestável (formação de Fe3C), (b) Arrefecimento curvas para uma liga hipoeutéticas com $\mathrm{CE}=4.0$...32 Figura 5: Nucleação e crescimento da ferrita abaixo da temperatura crítica superior, TUC perlita e abaixo da temperatura crítica mais baixa, TLC.

Figura 6: Estrutura cristalina de grafita em forma hexagonal que mostra a célula unitária e possíveis direções de crescimento.

Figura 7: Microestrutura e processamento básico para a obtenção dos ferros fundidos comerciais.

Figura 8: Ilustração esquemática de tipos de ferros fundidos com variação da morfologia da grafita, (a) floco/lamelar, (b) compacto/vermicular e (c) esferoidal/nodular.

Figura 9: Tipos de morfologias encontradas nos ferros fundidos cinzentos segundo a norma ASTM 247

Figura 10: Variação de propriedades mecânicas e térmicas em função da porcentagem de nódulos.

Figura 11: Tensão mecânica e variação de temperatura na FTM, em conjunto com resposta tensão-deformação. (a) carregamento FTM em fase, (b) carregamento FTM fora de fase.......44 Figura 12: Carregamento esquemático da FTM mostrando tensões de compressão durante o aquecimento, relaxação de tensão durante o patamar em alta temperatura e tensão residual durante o resfriamento.

Figura 13: Fluxograma dos experimentos a serem executados.

Figura 14: Bloco "Y" segundo a norma ASTM A476/476M [45].

Figura 15: Geometria e dimensões do corpo de prova utilizado no ensaio de tração nas temperaturas de $50^{\circ} \mathrm{C}$ e $420^{\circ} \mathrm{C}$ [48].

Figura 16: Dimensões do corpo de prova utilizado para o ensaio de FTM.

Figura 17: Equações básicas para tensões induzidas durante o ensaio de FTM. 51 
Figura 18: Modo de ensaio aplicado em FTM onde podem ser observadas as temperaturas do comando e resposta.

Figura 19: Configuração do software MPT para a realização do ensaio de FTM.

Figura 20: Máquina de ensaio MTS com (A) tubo de ventilação, (B) pirômetro, (C) garras refrigeradas, (D) espira de aquecimento por indução e (E) extensômetro para alta temperatura.

Figura 21: Leitura dos termopares e variações de temperatura na extensão da área útil do corpo de prova. (a) $50^{\circ} \mathrm{C} \mathrm{e} \mathrm{(b)} 420^{\circ} \mathrm{C}$.

Figura 22: Micrografia evidenciando a distribuição das grafitas no FFC, (a) matriz perlitica com ataque 3\% nital, (b) Análise quantitativa dos veios (média 10\%).

Figura 23: Micrografia evidenciando a distribuição das grafitas do FFV, (a) matriz composta por perlita (média 93\%) e ferrita (7\%) com ataque 3\% nital, (b) Análise quantitativa da grafita (média de 11\%)...... 58

Figura 24: Gráfico tensão x deformação dos ensaios de tração nas temperaturas 50 e $420^{\circ} \mathrm{C}$ para o FFC.

Figura 25: Gráfico tensão x deformação dos ensaios de tração nas temperaturas 50 e $420^{\circ} \mathrm{C}$ para o FFV.

Figura 26: Variação do módulo de elasticidade com a temperatura de ensaios para os materiais FFV e FFC.

Figura 27: Deformação térmica total de aproximadamente $0,577 \%$ para o intervalo de temperatura de $50-420^{\circ} \mathrm{C}$.

Figura 28: (a) FFC-CP2 108 ciclos (b) FFV-CP 610 ciclos. Análise do primeiro e segundo ciclo térmico por FTM. São detalhados o inicio de escoamento (B), atendimento de carga máxima em compressão (C), inicio (D) e final (E) do patamar de temperatura, inicio do carregamento trativo (F) e inicio da deformação plástica $(\mathrm{G})$, com atendimento da máxima tensão trativa (H). No segundo ciclo a tensão vai a zero em (I) e o escoamento é iniciado em $(\mathrm{J})$.

Figura 29: Análise da tensão nos dois primeiros ciclos térmicos em FTM. Observa-se a relaxação de tensão em ambos os tipos de ferro fundido.

Figura 30: (a) FFC-CP2 108 ciclos (b) FFV-CP 610 ciclos. Desenvolvimento tensão x deformação durante o ensaio FTM.

Figura 31: Evolução da histerese tensão x deformação plástica no ensaio de FTM, (a) FFCCP2, vida de 108 ciclos (b) FFV-CP vida de 610 ciclos.... 
Figura 32: Evolução das tensões durante os ciclos térmicos (FFC-CP1) falha por fratura em 97 Ciclos.

Figura 33: Evolução das tensões durante os ciclos térmicos (FFC-CP2) falha por inicio de queda em 108 ciclos.

Figura 34: Evolução das tensões durante os ciclos térmicos (FFC-CP3) falha por fratura em 116 ciclos.

Figura 35: Evolução das tensões durante os ciclos térmicos (FFC-CP4) falha por fratura em 147 ciclos.

Figura 36: Evolução das tensões durante os ciclos térmicos (FFC-CP5) falha por início de queda em 170 ciclos.

Figura 37: Evolução das tensões durante os ciclos térmicos (FFV-CP1) falha por fratura em 610 ciclos.

Figura 38: Evolução das tensões durante os ciclos térmicos (FFV-CP2) falha por inicio de queda em 800 ciclos.

Figura 39: Evolução das tensões durante os ciclos térmicos (FFV-CP3) falha por fratura em 585 ciclos.

Figura 40: Evolução das tensões durante os ciclos térmicos (FFV-CP4) falha por início de queda em 660 ciclos.

Figura 41: Detalhamento de posição do extensômetro e crescimento de trinca (a) início da trinca em face (b) início da trinca ao lado posterior.

Figura 42: Análise da superfície de fratura dos ferros fundidos cinzento e vermicular após submetidos ao ensaio de FTM.

Figura 43: Aspecto macrográfico da superfície de fratura do corpo de prova após o ensaio de FTM (FFV).

Figura 44: Superfície de fratura observada em MEV do ferro fundido (a) cinzento e (b)

vermicular.

Figura 45: Análise de oxidação exposto ao ciclo térmico em (a) FFV-CP 2, 800 ciclos e (b) FFC-CP5, 170 ciclos, podendo ser notado à oxidação durante a propagação de trinca.

Figura 46: Análise microestrutural do FFC fraturado após 170 ciclos, onde se nota à oxidação durante a propagação de trinca.

Figura 47: Perfil de trinca obtido no ensaio por FTM com amplitude de deformação de 0,577 $\%$, após 800 ciclos onde ocorreu a falha do corpo de prova pelo critério de $10 \%$ da tensão máxima (FFV-CP2).

Figura 48: Detalhe de trincas (setas) por toda extensão na matriz perlítica no FFV. 
Figura 49: Perfil de trinca obtido no ensaio por FTM com amplitude de deformação de $0,6 \%$, após 170 ciclos.

Figura 50: Propagação de trinca indicado pelas letras A e B, no ferro fundido cinzento submetido a 170 ciclos, $\mathrm{CP}-2$ 


\section{LISTA DE TABELAS}

Tabela 1: Composição química nominal dos ferros fundidos cinzento e vermicular................57

Tabela 2: Resultados das análises quantitativas de grafita para o FFC ..................................58

Tabela 3: Resultados das análises quantitativas de grafita para o FFV ..................................58

Tabela 4: Resultados dos ensaios de tração do material FFC na temperatura $50{ }^{\circ} \mathrm{C}$..................60

Tabela 5: Resultados dos ensaios de tração do material FFC na temperatura de $420{ }^{\circ} \mathrm{C}$..........6 60

Tabela 6: Resultados dos ensaios de tração do material FFV na temperatura de $50{ }^{\circ} \mathrm{C}$............61

Tabela 7: Resultados dos ensaios de tração do material FFV na temperatura de $420{ }^{\circ} \mathrm{C}$..........61

Tabela 8: Redução das propriedades mecânicas devido ao aquecimento em $420^{\circ} \mathrm{C}$ no material

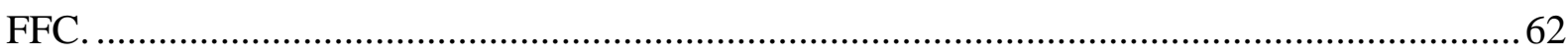

Tabela 9: Redução das propriedades mecânicas devido ao aquecimento em $420^{\circ} \mathrm{C}$ no material FFV 62

Tabela 10: Tensões máxima obtidas durante o ensaio de FTM …........................................... 75

Tabela 11: Vida em FTM dos ferros fundidos cinzento e vermiculares. ................................. 75 



\section{LISTA DE ABREVIATURAS E SIGLAS}

\begin{tabular}{ll} 
ABNT & Associação Brasileira de Normas Técnicas \\
ASTM & American Society for Testing Materials \\
CP & Corpo de prova \\
EF & Em fase \\
FF & Fora de Fase \\
FTM & Fadiga Termomecânica \\
FFC & Ferro fundido cinzento \\
FFV & Ferro fundido vermicular \\
FAC & Fadiga de alto ciclo \\
FBC & Fadiga de baixo ciclo \\
FI & Fadiga isotérmica \\
CE & Carbono Equivalente \\
TL & Temperatura Liquidus \\
TG & Grafita eutética \\
MPT & Multiple Purpose Testing \\
L & Deformação inicial \\
N & Nucleação de trinca \\
P & Propagação estável \\
F & Propagação instável ou falha final \\
EESC & Escola de Engenharia de São Carlos \\
MO & Microscópio ótico \\
NEMAF & Núcleo de Ensaios de Materiais e Análise de falhas \\
SAE & Society of Automotive Engineers \\
SMM & Departamento de Engenharia de Materiais \\
USP & Universidade de São Paulo \\
\hline
\end{tabular}





\section{LISTA DE SÍMBOLOS}

\begin{tabular}{|c|c|}
\hline Al & Alumínio \\
\hline B & Borro \\
\hline $\mathbf{B a}$ & Bário \\
\hline Be & Berílio \\
\hline $\mathbf{B i}$ & Bismuto \\
\hline $\mathbf{C}$ & Carbono \\
\hline $\mathbf{C a}$ & Cálcio \\
\hline Ce & Cério \\
\hline Co & Cobalto \\
\hline $\mathrm{CO}_{2}$ & Oxido de Carbono \\
\hline $\mathbf{C r}$ & Cromo \\
\hline $\mathbf{C u}$ & Cobre \\
\hline $\mathbf{E}$ & Módulo de Young ou de Elasticidade \\
\hline $\mathbf{F e}$ & Ferro \\
\hline $\mathrm{Fe}_{3} \mathrm{C}$ & Cementita \\
\hline GPa & GigaPascal \\
\hline $\mathbf{h}$ & Horas \\
\hline $\mathbf{k N}$ & KiloNewton \\
\hline Mg & Magnésio \\
\hline $\min$ & Minuto \\
\hline $\mathbf{m m}$ & Milímetro \\
\hline Mn & Manganês \\
\hline MPa & MegaPascal \\
\hline $\mathbf{O}$ & Oxigênio \\
\hline Sb & Antmônio \\
\hline $\mathbf{S i}$ & Sílicio \\
\hline $\mathbf{T i}$ & Titânio \\
\hline$\mu \mathrm{m}$ & Mícrons \\
\hline${ }^{\circ} \mathbf{C}$ & Graus Celsius \\
\hline$\gamma$ & Austenita \\
\hline$\alpha$ & Ferrita \\
\hline$\varepsilon$ & Deformação total \\
\hline
\end{tabular}


$\boldsymbol{\varepsilon}_{\mathbf{e l}} \quad$ Deformação elástica

$\boldsymbol{\varepsilon}_{\mathbf{p l}} \quad$ Deformação plástica

$\boldsymbol{\varepsilon}_{\text {ter }} \quad$ Deformação térmica

$\boldsymbol{\varepsilon}_{\text {mec }} \quad$ Deformação mecânica

$\Delta \mathbf{T} \quad$ Diferença de temperatura

$\Delta \boldsymbol{\varepsilon} \quad$ Variação de deformação 


\section{SUMÁRIO}

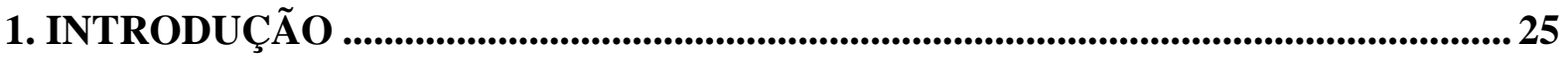

2. OBJETIVO PRINCIPAL .........................................................................................27

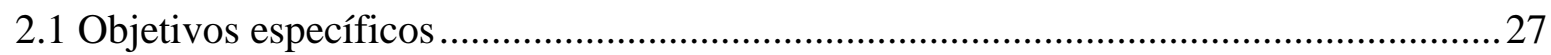

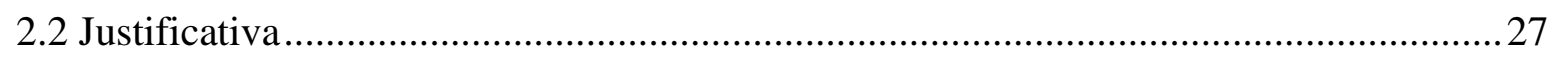

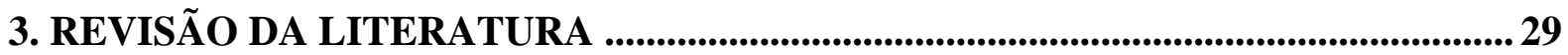

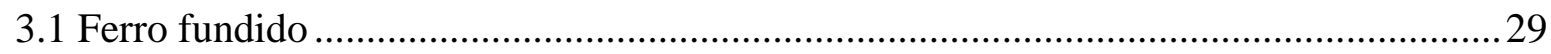

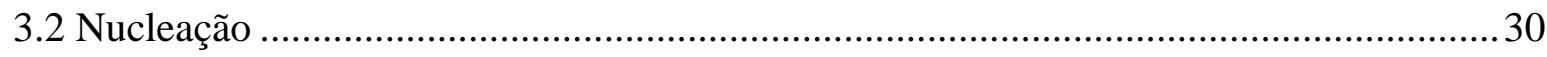

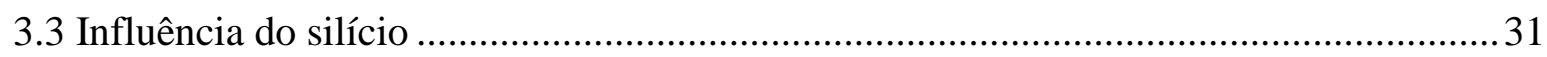

3.4 Solidificação dos hipoeutéticos e hipereutéticos nos ferros fundidos .............................. 32

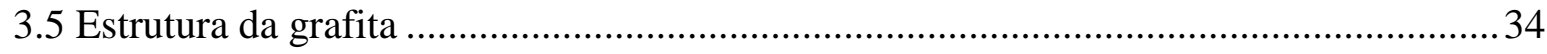

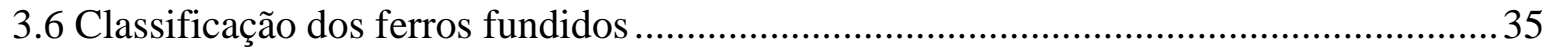

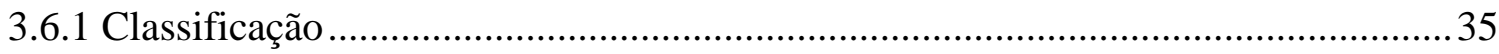

3.6.2 Ferro fundido cinzento (Floco/lamelar).................................................................. 37

3.6.3 Tipos e morfologias da grafita em ferros fundidos cinzento ……………………........ 38

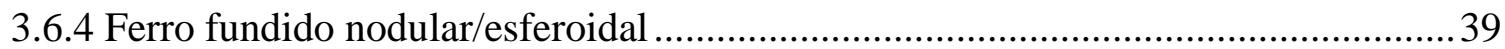

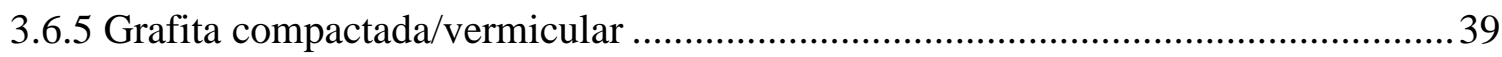

3.6.6 Outros tipos de ferros fundidos ........................................................................ 40

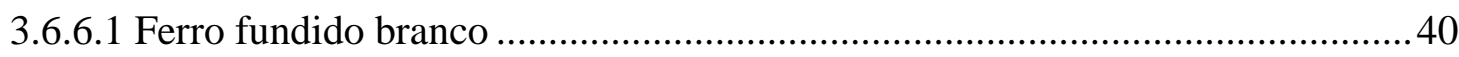

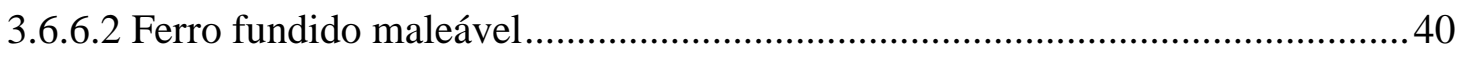

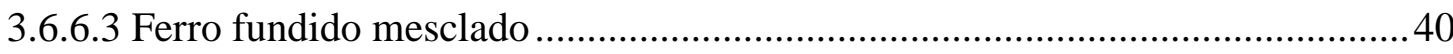

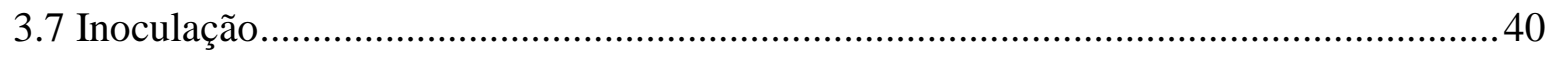

3.8 Propriedades mecânicas e térmicas .............................................................................. 41

3.9 Introdução à fadiga termomecânica........................................................................... 42

3.10 Fenômeno da fadiga termomecânica em motores .......................................................... 43

3.11 Mecanismos e danos nos ferros fundidos sob FTM ……………………………........ 44

3.12 Degradação microestrutural durante FTM .................................................................46

4. MATERIAIS E MÉTODOS ..................................................................................... 4

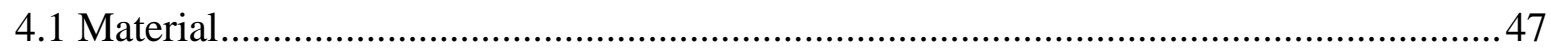

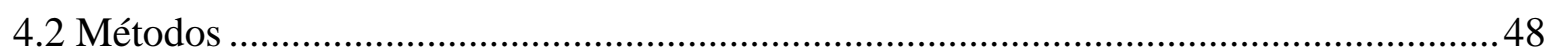




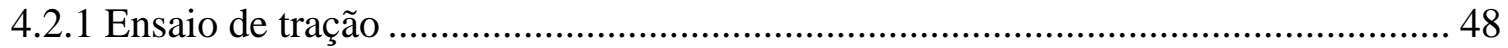

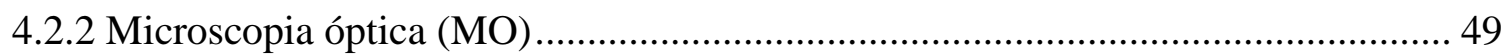

4.2.3 Microscopia eletrônica de varredura (MEV) ..................................................... 49

4.2.4 Ensaio de fadiga termomecânica..................................................................... 50

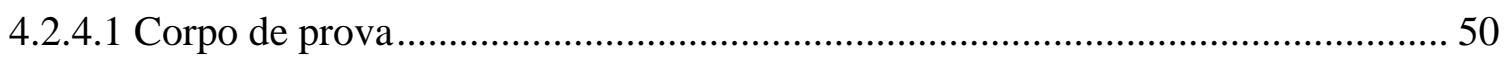

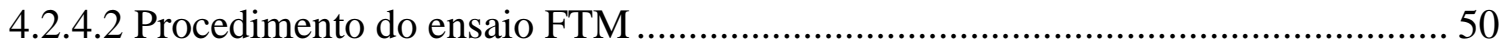

4.2.4.3 O ensaio de fadiga termomecânica .................................................................... 51

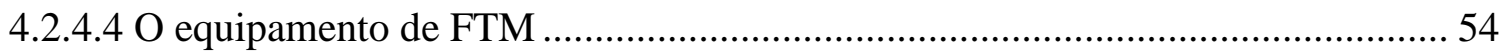

4.2.4.5 Controle da temperatura durante o ensaio de FTM........................................... 55

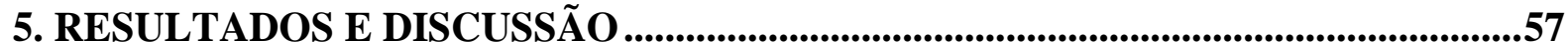

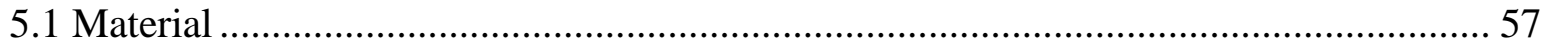

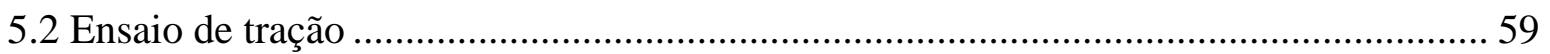

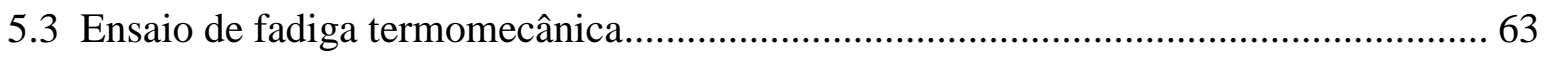

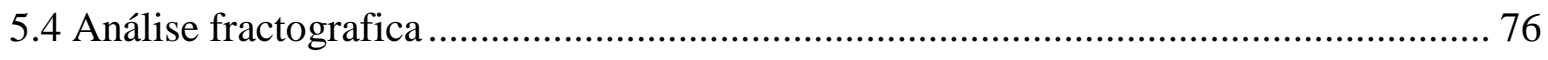

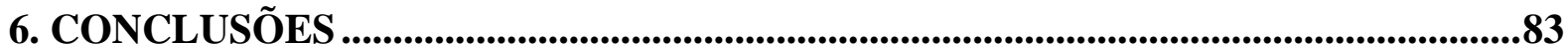

7. SUGESTÕES PARA TRABALHOS FUTUROS...............................................................85

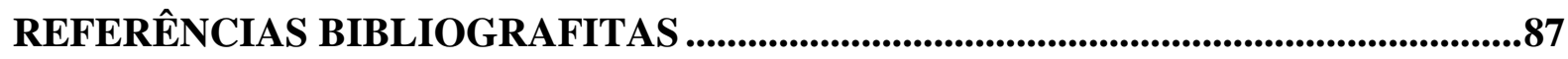




\section{INTRODUÇÃO}

Nos motores de combustão interna, a repetição dos ciclos de partida e parada dos motores fazem com que a carga mecânica se agrave em algumas partes do motor, como nos blocos, cilindros e cabeças de cilindro, isso pode levar a trincas devido a tensões localizadas que se desenvolvem como resultado do gradiente térmico. Este fenômeno é conhecido como fadiga termomecânica (FTM), e acredita-se ser o processo dominante responsável pelas trincas desenvolvidas nos componentes do motor [1].

$\mathrm{Na}$ cabeça do cilindro, quando o motor está em operação a temperatura de trabalho pode chegar à $420^{\circ} \mathrm{C}$, quando o motor é desligado a temperatura cai à temperatura ambiente novamente. Estas mudanças bruscas de temperatura podem provocar danos na superfície, que por sua vez pode resultar na iniciação de trincas em um número de ciclos baixo [2].

No cabeçote do cilindro a insuficiência microestrutural por FTM ocorre principalmente nas regiões da válvula e nas áreas entre entrada e a saída devido sua geometria complexa, como eles estão sujeitos a carregamento fora de fase (FF), isto é, a tensão máxima ocorre em temperatura mínima, acontece uma deficiência térmica e assim provocando variações de temperaturas durante toda extensão no cabeçote, devido a este fenômeno surge tensões residuais levando à deformações que afeta sua microestrutura, suas propriedades mecânicas e desempenho em altas temperaturas [3].

O material mais usado para estes trabalhos são os ferros fundidos, que consistem em partículas de grafita numa matriz metálica. Este material fornece a combinação adequada de propriedades térmicas e mecânicas para conseguir o desempenho desejado. A grafita proporciona boa condutividade térmica, enquanto a matriz é responsável pela adequada propriedade mecânica.

No entanto, a microestrutura pode evoluir instavelmente durante a operação, podendo deteriorar estas propriedades térmicas e mecânicas. Por exemplo, a descolagem da grafita na matriz, a oxidação interna ou a decomposição de perlita em ferrita, podem ter um grave impacto sobre as propriedades [3,4].

De acordo com Lohe et al. [4], vários mecanismos podem ocorrer durante um carregamento em ciclo térmico: deformação, oxidação, decomposição da perlita, engrossamento da microestrutura, iniciação de trincas e sua propagação. Alem disto, sabe-se que a maioria dos mecanismos de danos em microescala são dependentes da temperatura e do tempo. 
No ferro fundido, em elevada temperatura, a superfície da grafita começa a oxidar imediatamente e ocorre uma perda gradualmente de carbono. O oxigênio penetra na estrutura, ao longo das partículas de grafita levando a oxidação do carbono em uma formação de reação $\left(\mathrm{CO}\right.$ e $\left.\mathrm{CO}_{2}\right)$, deixando cavidades vazias [5]. Buni et al. [6], descreve que a oxidação da grafita enfraquece a ligação com a matriz e resulta na criação de furos.

É importante compreender o fenômeno de FTM, assim como, caracterizar a evolução microestrutural e seu comportamento em cargas mecânicas e térmicas, deste modo identificar os mecanismos que afeta os motores de combustão interna. Esta pesquisa teve a finalidade de estudar trincas localizadas em cabeçotes de cilindro, devido a ciclos no ato liga-desliga de motores automotivos.

A temperatura do ciclo térmico representa a situação durante o liga-desliga na vida útil do motor. Deste modo, os resultados dos testes são projetados para representar o que realmente ocorre com os motores.

A pesquisa foi realizada em um projeto entre o Departamento de Engenharia de Materiais da Escola de Engenharia de São Carlos (EESC), em experimental no grupo Núcleo de Ensaios de Materiais e Análise de falhas (NEMAF) e a empresa Fundição TUPY, a fim de melhorar os materiais e prever o desempenho a FTM. Para este fim, modelos matemáticos estão sendo construídos, para simular os fenômenos que atuam no material durante o trabalho. Uma compreensão da relação entre microestrutura e propriedades não só permite prever o desempenho, mas também oferece a oportunidade de melhorar e produzir novos materiais. 


\section{OBJETIVO PRINCIPAL}

O objetivo principal da pesquisa é identificar e compreender os mecanismos de dano que controlam o fenômeno de fadiga termomecânica nos ferros fundidos cinzento e vermicular, com a finalidade de prever a vida e aumentar a confiabilidade dos motores por combustão interna.

\subsection{Objetivos específicos}

$\checkmark$ Investigar o efeito em altas temperaturas diante de ciclos térmicos, observando a evolução da microestrutura dos ferros fundidos cinzento e vermicular.

$\checkmark$ Caracterizar a vida útil dos materiais estudados, utilizando corpos de prova segundo a norma, simulando as cargas cíclicas as que as válvulas, e cabeçote de cilindro são submetidos durante seu funcionamento.

$\checkmark$ Desenvolver um modelo para prever o tempo de vida sob FTM, que exibe um resultado satisfatório, a fim de compreender a relação entre microestruturas e vidas em FTM.

$\checkmark$ Analisar mudanças microestruturais induzidas durante os ciclos térmicos, e pela evolução da histeresse em tensão e compressão.

$\checkmark$ Caracterizar trincas por FTM, e descobrir mecanismos predominantes que levam seu desenvolvimento e propagação.

\subsection{Justificativa}

Motores de combustão interna possuem uma geometria complexa que inclui cavidades para resfriamento forçado. $\mathrm{O}$ aquecimento súbito devido à ignição dos veículos e o resfriamento ao desligar dos mesmos acarreta gradientes térmicos e diferenciados dentro do material que resulta em tensões elevadas.

A aplicação dos ciclos térmicos oriundos destes aquecimentos e resfriamentos bruscos leva a formação de trincas localizadas, mostrada na Figura 1, ocorrentes de um fenômeno conhecido como fadiga termomecânica.

Os ferros fundidos têm sido uma escolha comum para a fabricação dos blocos e cabeçotes dos motores a diesel. Deste modo, a obtenção de conhecimentos do comportamento em fadiga termomecânica é de grande importância, pois possibilitará a previsão da vida, 
melhoria das propriedades das novas ligas e o aumento da confiabilidade dos blocos e cabeçotes dos motores a diesel [3].

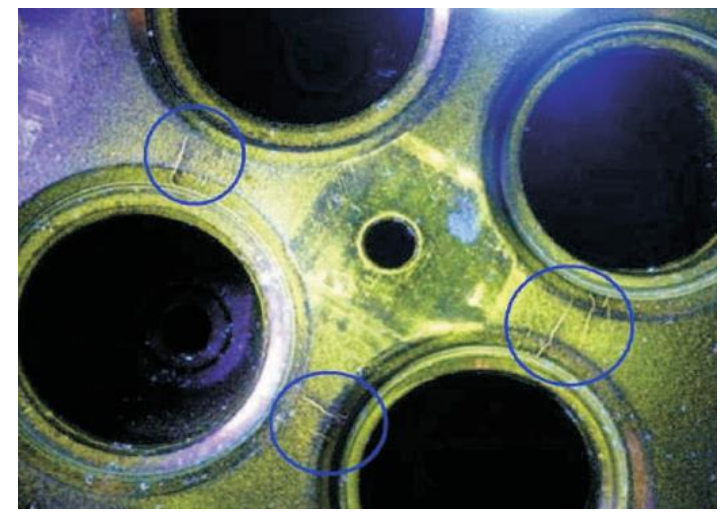

(a)

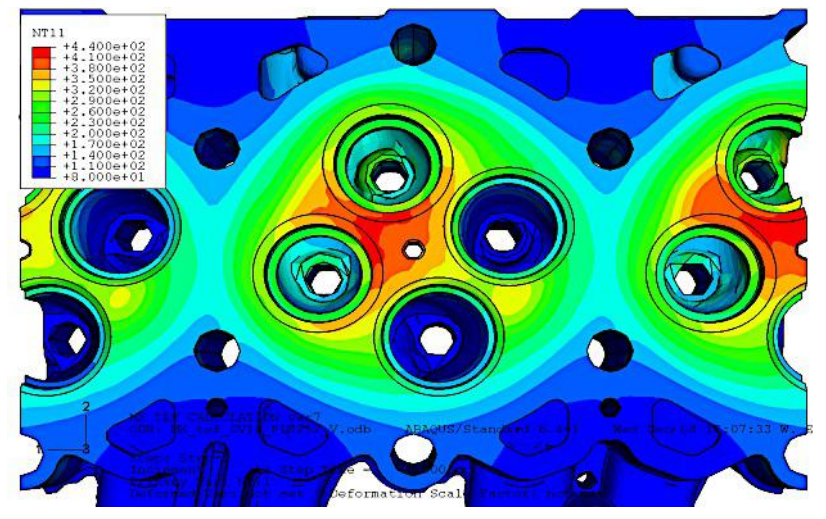

(b)

Figura 1: Locais críticos de válvula e cabeças de cilindro sob condições de FTM, (a) trincas macroscópicas em cabeças de cilindro e (b) distribuição de temperatura em locais críticos. Fonte: GHODRAT, 2013. 


\section{REVISÃO DA LITERATURA}

\subsection{Ferro fundido}

O termo ferro fundido tem uma definição ampla de ligas ferrosas, que contém em sua composição uma grande quantidade de carbono, variando entre 2,1 a $4,5 \%$ e de silício entre 1 a $3 \%$. Além desses principais elementos $\mathrm{C}$ e $\mathrm{Si}$, podem ser adicionados outros elementos como: $\mathrm{Ba}, \mathrm{Bi}, \mathrm{B}$, em teores menores que $0,01 \%$ e $\mathrm{Al}, \mathrm{Sb}, \mathrm{Ce}$, Co e $\mathrm{Cr}$ em uma porcentagem maior que 0,01\% [8]. Em comparação com o aço, o ferro fundido tem um teor de carbono e silício muito maior, o que conduz a presença de grafita que se torna a fase rica em carbono na microestrutura de ferro fundido, que é geralmente ausente nos aços.

Referindo-se apenas ao diagrama binário Fe-C é importante notar que o silício e outros elementos de liga podem mudar consideravelmente o máximo de solubilidade de carbono em austenita $(\gamma)$. Porem, em casos excepcionais, as ligas com menos de $2 \%$ de $\mathrm{C}$ pode solidificar com uma estrutura eutética e, por consequência ainda pertencer à família dos ferros fundidos $[9]$.

Como é mostrado na Figura 2, parte da solidificação do ferro fundido ocorre no ponto eutético. Uma vez que as composições da maioria dos ferros fundidos são em torno do ponto eutético no sistema $\mathrm{Fe}-\mathrm{C}$, as temperaturas de fusão são correlacionadas com a temperatura eutética geralmente variando de 1150 a $1200^{\circ} \mathrm{C}$, que é cerca de $300{ }^{\circ} \mathrm{C}$ mais baixa do que o ponto de fusão do ferro puro [8-9]. 


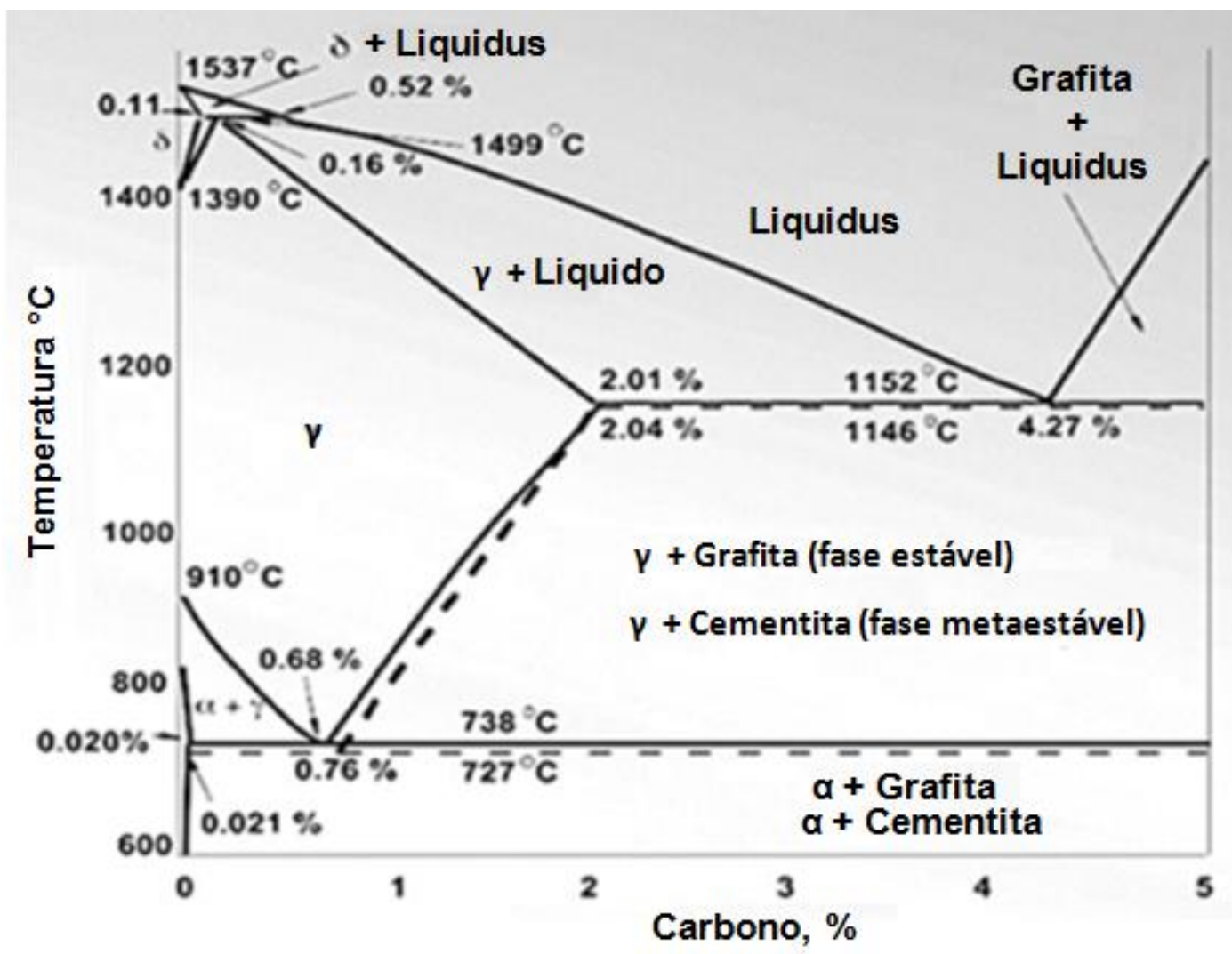

Figura 2: Diagrama ferro carbono. Fonte: Adaptado de DAVIS, 1996.

\subsection{Nucleação}

Dependendo do potencial de nucleação que pode ocorrer diretamente no líquido, pela junção dos átomos (nucleação homogênea) ou a partir de superfícies ou núcleos já existentes (nucleação heterogênea), da composição química, a taxa de resfriamento, o ferro fundido pode solidificar termodinamicamente estável ou metaestável [10]. A composição química é o fator mais dominante que determina o potencial de grafitização, que promove a formação de grafita em vez de carbonetos de ferro.

No diagrama Fe-C da Figura 2, estão representados tanto a fase estável quanto a metaestável. Se a solidificação é metaestável no eutético se forma a austenita $(\gamma)$ e a cementita $\mathrm{Fe}_{3} \mathrm{C}$, enquanto na solidificação do eutético estável se forma a austenita e a grafita. Estes dois tipos de eutéticos apresenta grandes diferenças em propriedades tais como resistência, dureza, ductilidade e condutividade térmica [10, 11]. 


\subsection{Influência do silício}

Para os ferros fundidos a presença do silício muda o ponto eutético de uma liga binária, no caso do Fe-C sem a presença deste elemento, se torna no ponto 4,3\% de C, mas com sua adição diminui a estabilidade do $\mathrm{Fe}_{3} \mathrm{C}$ e assim aumenta a estabilidade da ferrita no campo $\alpha$ e acaba constringindo o campo $\gamma$. Como o silício é encontrado em grande quantidade nesses materiais pode ser chamado de um sistema ternário Fe-C-Si [12, 13]. Na Figura 3 são indicadas as estruturas resultantes do ferro fundido na variação de porcentagem de carbono silício.

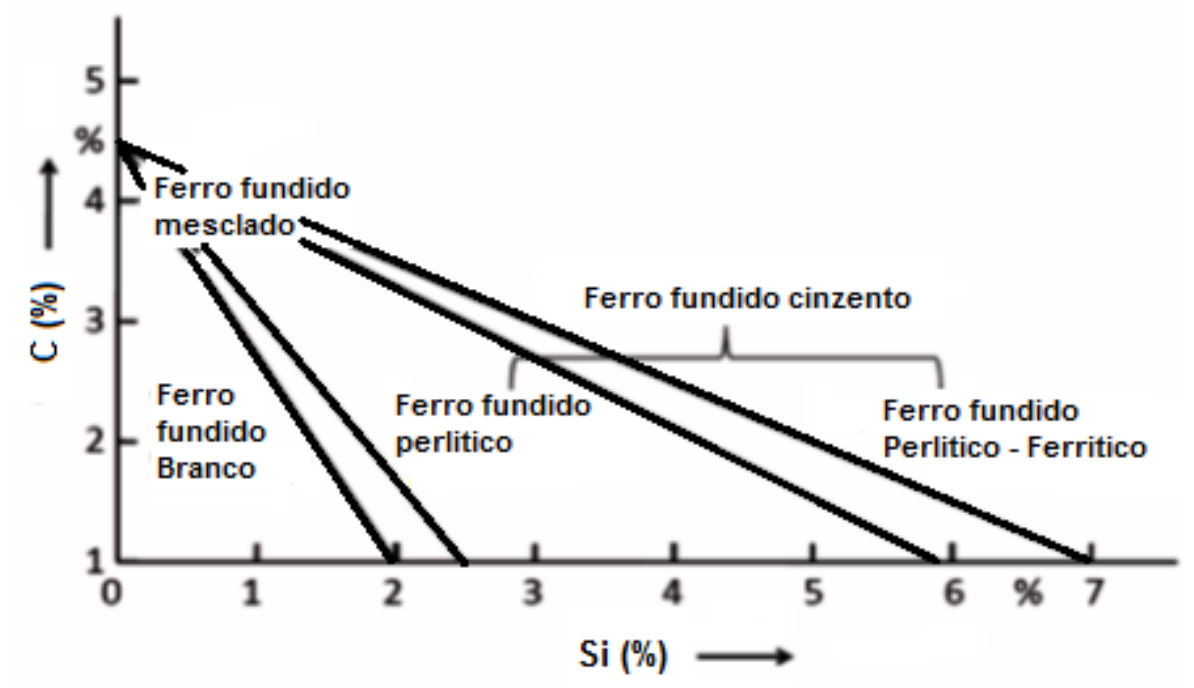

Figura 3: Diagrama indicando as estruturas dos ferros fundidos resultantes com a variação de silício.

Fonte: Adaptado de VELICHKO, 2008.

Outro elemento que pode alterar o diagrama Fe-C é o fósforo, quando em maiores quantidades presentes na liga acaba ocasionado um papel no comportamento de transformação. Pode ser conveniente combinar o efeito do silício, do carbono e do fósforo em um único fator, chamado carbono equivalente (CE) expressa com a seguinte equação [14].

$$
C E=\% C=\frac{1}{3}(\% S i+\% P)
$$

O carbono equivalente é empregado para determinar o quão perto uma dada composição do ferro está da composição eutética, por exemplo, um CE de 3,9\% representa uma liga correspondente a uma composição hipoeutética, ou seja, com fase austenita, 
enquanto que um CE de 4,6\% representa uma liga que corresponde a uma composição hipereutética com a grafita ou cementita na solidificação [13, 14].

\subsection{Solidificação dos hipoeutéticos e hipereutéticos nos ferros fundidos}

Dependendo da composição química a solidificação dos ferros fundidos pode ocorrer em dois modos diferentes, hipoeutéticos com CE menores que 4,3\% ou hipereutéticos com CE maior que 4,3\% como mostrado na Figura 4.

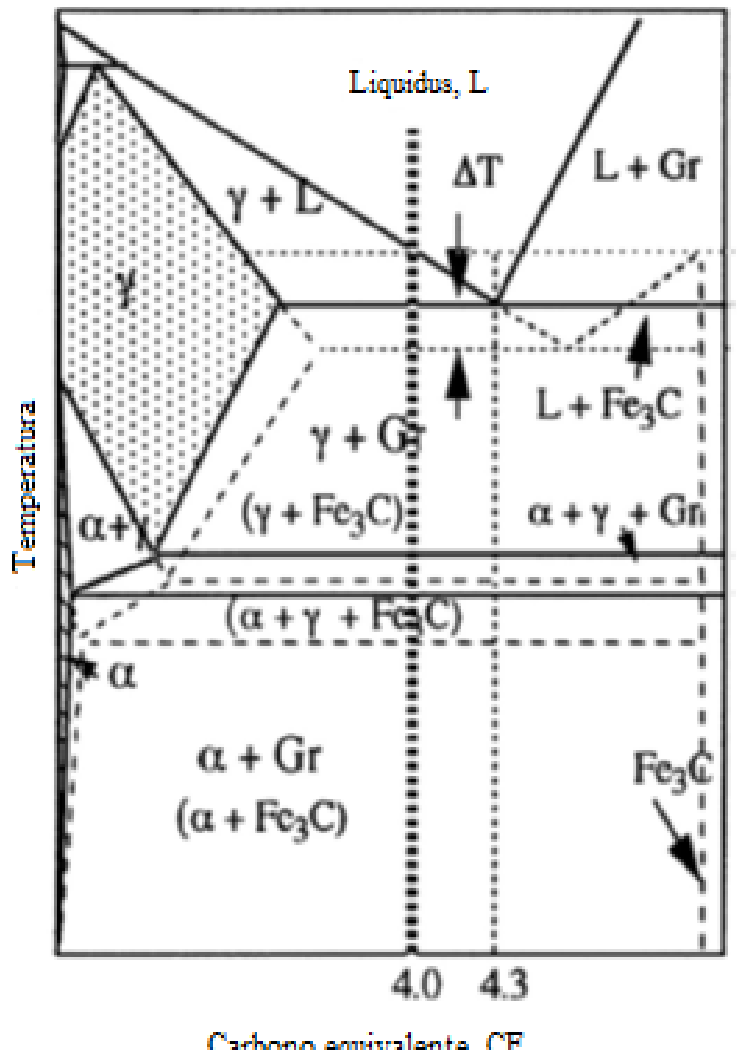

Carbono equivalente, $\mathrm{CE}$

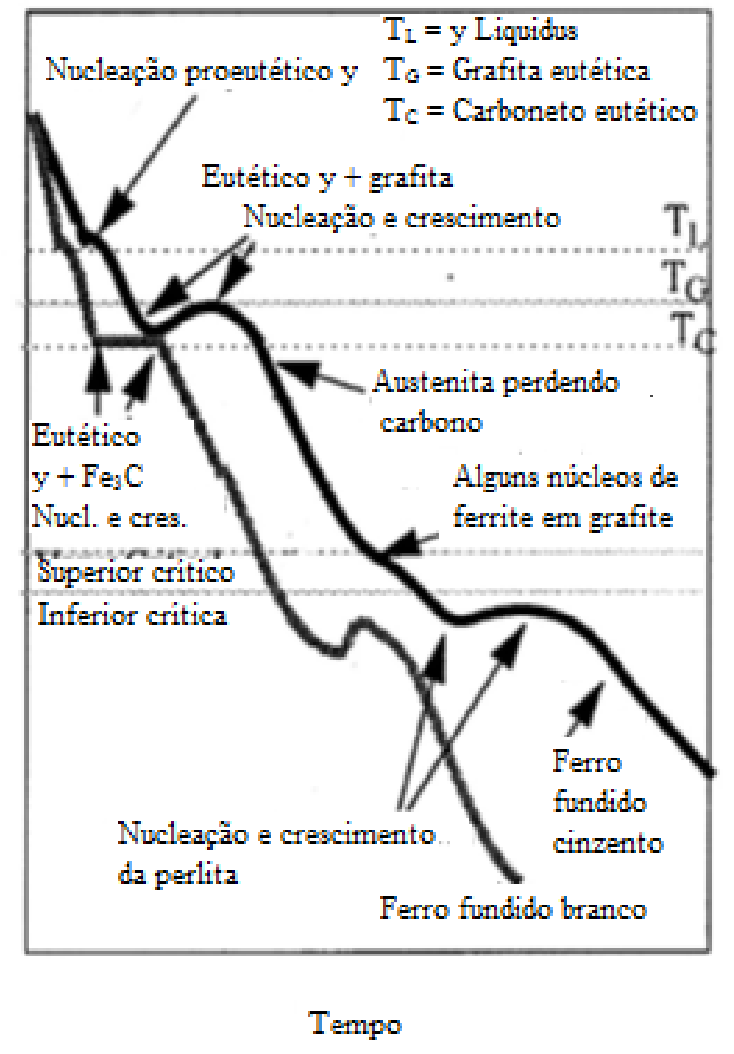

Tempo

Figura 4: Desenho esquemático mostrando a solidificação de uma liga hipoeutética, onde linhas sólidas: sistema estável (formação de grafita) e, linhas tracejadas: metaestável (formação de $\mathrm{Fe} 3 \mathrm{C}$ ), (b) Arrefecimento curvas para uma liga hipoeutéticas com $\mathrm{CE}=4.0$. Fonte: Adaptado de RUNDMAN, 2008.

Na solidificação a primeira fase a se formar é a austenita na região liquidus (TL). As dendritas de austenita crescem na região liquidus, no qual é enriquecido em carbono até a temperatura eutética (região TG). Após essa região se resulta um equilíbrio no eutético contendo austenita e grafita, produzindo uma microestrutura contendo dendritas de austenita rodeado por um eutético, com a mistura de austenita e grafita. 
No resfriamento abaixo da $\mathrm{TG}$, o teor de carbono da austenita diminui à medida que o carbono difunde-se para a fase da grafita contida no seu eutético [15]. Quando a temperatura crítica superior é alcançada começa a nucleação da ferrita e da grafita estável.

A nucleação da ferrita ocorre na interface da grafita, sendo depositado o carbono a partir da austenita nas partículas de grafita existentes. Na solidificação com um determinado resfriamento lento, a fase ferrita pode continuar a crescer na austenita ocorrendo em sua estrutura final apenas ferrita e grafita, como previsto no diagrama de fases estáveis. No entanto, se na solidificação o resfriamento for ocorrido rapidamente, ou com presença de alguns elementos de liga, a austenita pode se transformar em perlita, onde ocorre a mistura da ferrita eutetóide e da cementita $\left(\mathrm{Fe}_{3} \mathrm{C}\right)[15,16]$. Em alguns casos essa mudança pode ocorrer de estável para transformações metaestáveis por causa da diminuição da temperatura. Por exemplo, a austenita pode se transformar primeiro em ferrita estável abaixo da temperatura crítica superior da grafita, enquanto que abaixo da temperatura critica inferior a austenita pode se transformar em perlita mostrado na Figura 5.

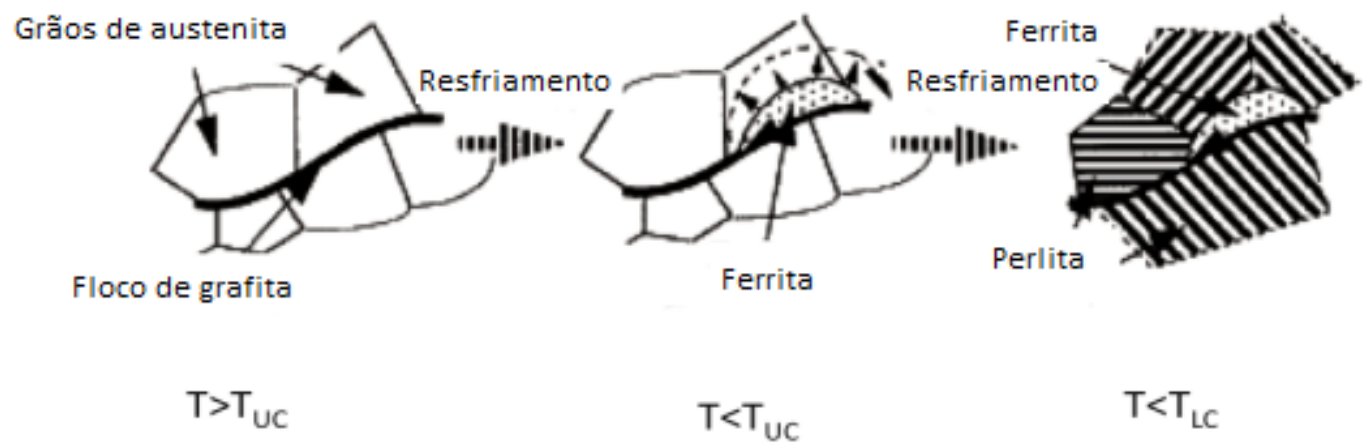

Figura 5: Nucleação e crescimento da ferrita abaixo da temperatura crítica superior, TUC perlita e abaixo da temperatura crítica mais baixa, TLC.

Fonte: Adaptado de RUNDMAN, 2008.

$\mathrm{Na}$ solidificação de um ferro fundido hipereutetóide, a fase primária consiste em grafita. O processo de solidificação é similar aos dos ferros fundidos hipoeutéticos com formação de células eutéticas, quando a primeira fase se forma ocorrendo à diminuição do teor de carbono no banho, tendo em vista que, quando na composição do eutético se forma nódulos de grafita, posteriormente serão envolvidos por invólucro de austenita [10]. O formato da grafita será dependente do teor residual dos elementos grafitizantes na sua composição química. 


\subsection{Estrutura da grafita}

A fim de identificar as propriedades dos ferros fundidos, a estrutura da fase da grafita deve ser bem compreendida. A estrutura do cristal de grafita consiste em planos de anéis hexagonais chamada de plano basal [18], os quais consistem de átomos empilhados em paralelo uns ao outro perpendicular ao eixo $\mathrm{C}$ mostrado esquematicamente na Figura 6.

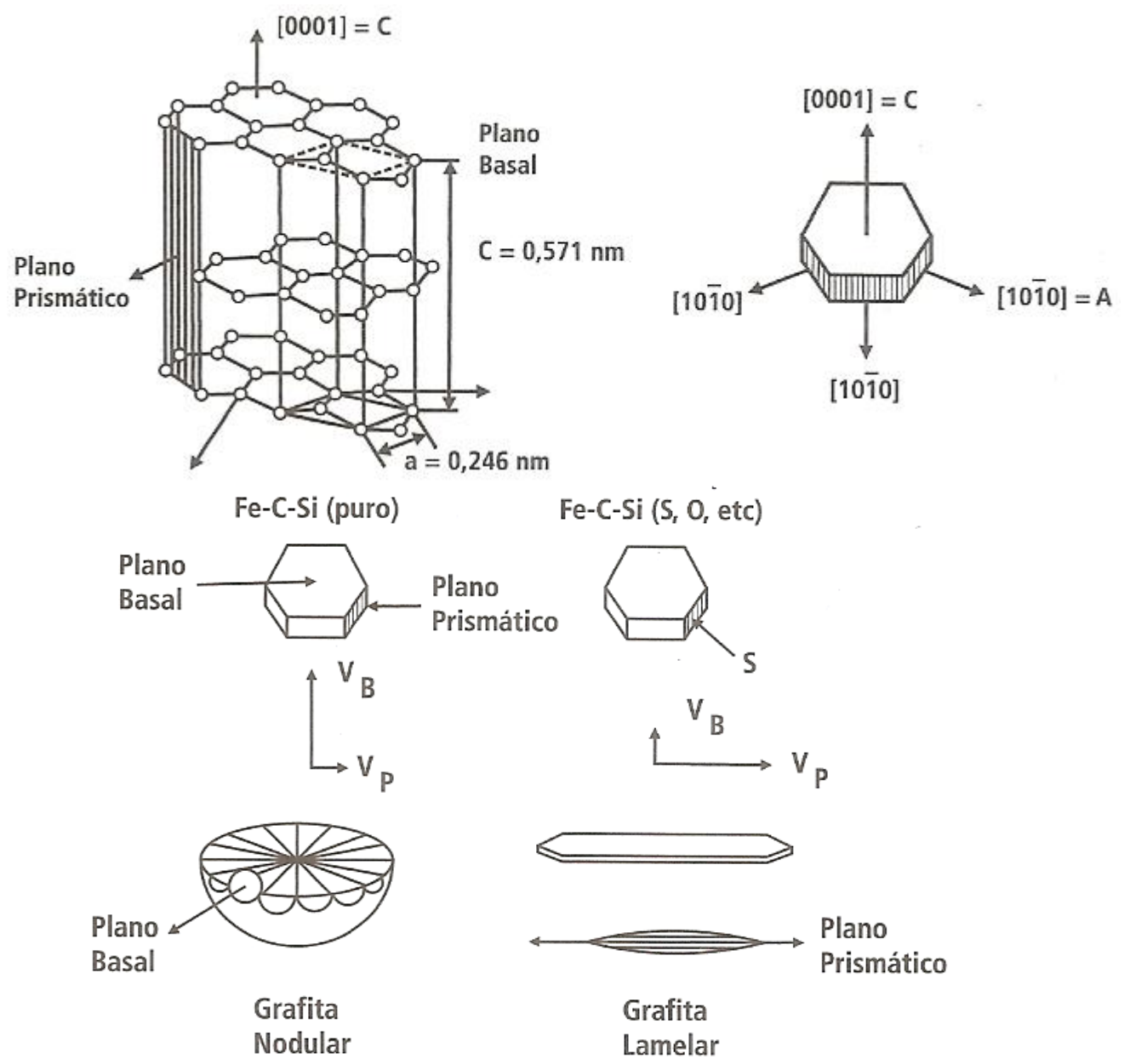

Figura 6: Estrutura cristalina de grafita em forma hexagonal que mostra a célula unitária e possíveis direções de crescimento.

Fonte: GUESSER, 2009.

Em sua camada externa, cada átomo de carbono possui quatro átomos de valência, três dos quatro elétrons de valência são amarrados em fortes ligações covalentes nos planos basais e o restante estabelece um vínculo com os planos basais adjacentes com forças de Van Der Walls [18]. Os elétrons envolvidos nas ligações covalentes fornecem boa condutividade elétrica e térmica da grafita, por outro lado entre estes planos basais a ligação, sendo mais fraca na sua estrutura permite o movimento e deslizamento entre as placas basais. Este recurso 
explica um número de propriedades características da grafita, tal como sua resistência limitada, sua auto lubrificação e baixa resistência ao cisalhamento [8, 18].

O mecanismo de crescimento de cristais da grafita se desenvolve a partir de sua estrutura anisotrópica, o plano normal ao cristal $\mathrm{C}<0001\rangle$, cresce lateralmente nos planos <1010>. Alguns elementos tais como: alumínio, antimônio, arsênico, bismuto, magnésio, cálcio e cério, pode inibir o crescimento nas direções preferenciais [8, 18, 19]. Esta inibição de crescimento pode levar a formação de morfologias esferoidal ou compactadas, como consequência das diferentes morfologias de cristal da grafita, pode-se dizer que a grafita apresenta anisotropia cristalina pronunciada à medida que o material se comporta de maneira diferente nas direções de A e C.

$\mathrm{O}$ crescimento no plano basal na direção $\mathrm{C}$ resulta em grafita nodular enquanto que a grafita lamelar se resulta na direção A [23].

\subsection{Classificação dos ferros fundidos}

\subsubsection{Classificação}

A princípio, a primeira classificação de ferro fundido foi baseada no aspecto visual da superfície da fratura, dois tipos eram conhecidos sendo eles: ferro fundido branco, que exibe uma superfície branca e cristalina, por sua fratura ocorrer ao longo das placas de carboneto de ferro $\left(\mathrm{Fe}_{3} \mathrm{C}\right)$, e o ferro fundido cinzento que exibe uma superfície cinza pela fratura ocorrer ao longo das grafitas [8]. Um esquema dos tipos mais comuns de ferro fundido comercial com base na grafitização e processamento básico está resumido na Figura 7. 


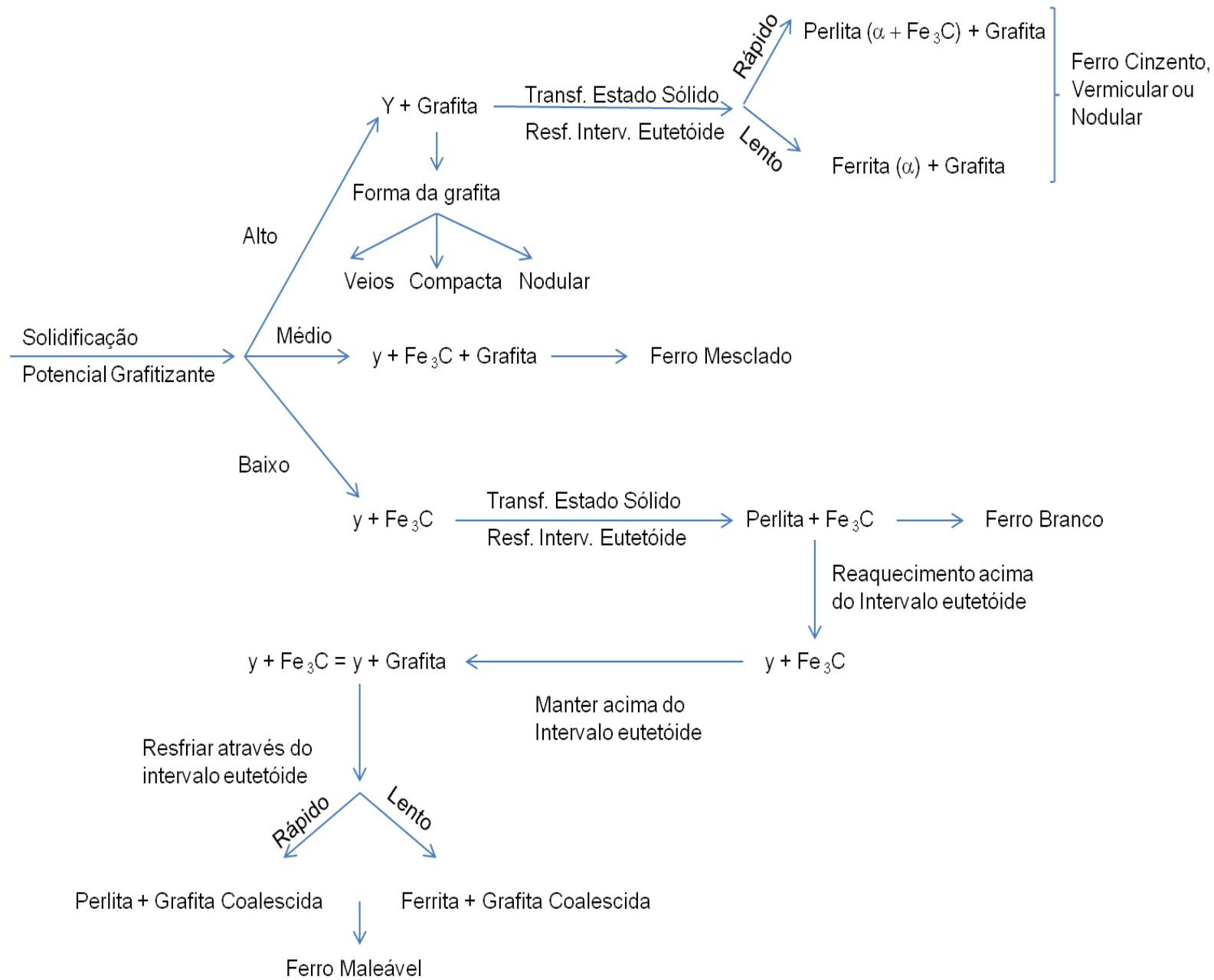

Figura 7: Microestrutura e processamento básico para a obtenção dos ferros fundidos comerciais.

Fonte: Adaptado de DAVIS, 1996.

As características microestruturais dos ferros fundidos e suas classificações são possíveis devido a este material ser constituído por partículas de grafita ou $\mathrm{Fe}_{3} \mathrm{C}$ em uma matriz de ferro. Assim os ferros fundidos podem ser classificados com base na morfologia da grafita e/ou na matriz do metal. Essa matriz pode ser constituída por ferrita, perlita, austenita, martensita, bainita ou com a combinação destas fases [10, 21].

A morfologia da grafita depende da direção do crescimento dominante, estas diferentes direções durante a solidificação são mostrada na Figura 8, pode ser visto que o crescimento preferencial da grafita pode ocorrer ao longo do eixo A ou C. Com essa variedade de morfologias da grafita, dependendo da composição química e da taxa de resfriamento ocorre um grande efeito nas propriedades mecânicas, ou seja, essas propriedades dependem fortemente sobre a forma e a interligação das partículas da grafita. 
As formas nodulares melhoram as propriedades mecânicas, enquanto que as na forma de flocos alongadas enfraquecem mecanicamente, devido ao ponto de concentração de tensões, mas tem boa lubrificação e absorção de vibrações. [10, 20,21].

Os ferros fundidos são classificados de acordo com as morfologias das grafitas, assim podem ser classificadas em três principais classes:

- Grafita em forma de flocos ou lamelas;

- Grafita compactada ou vermicular;

- Grafita nodular ou esferoidal.

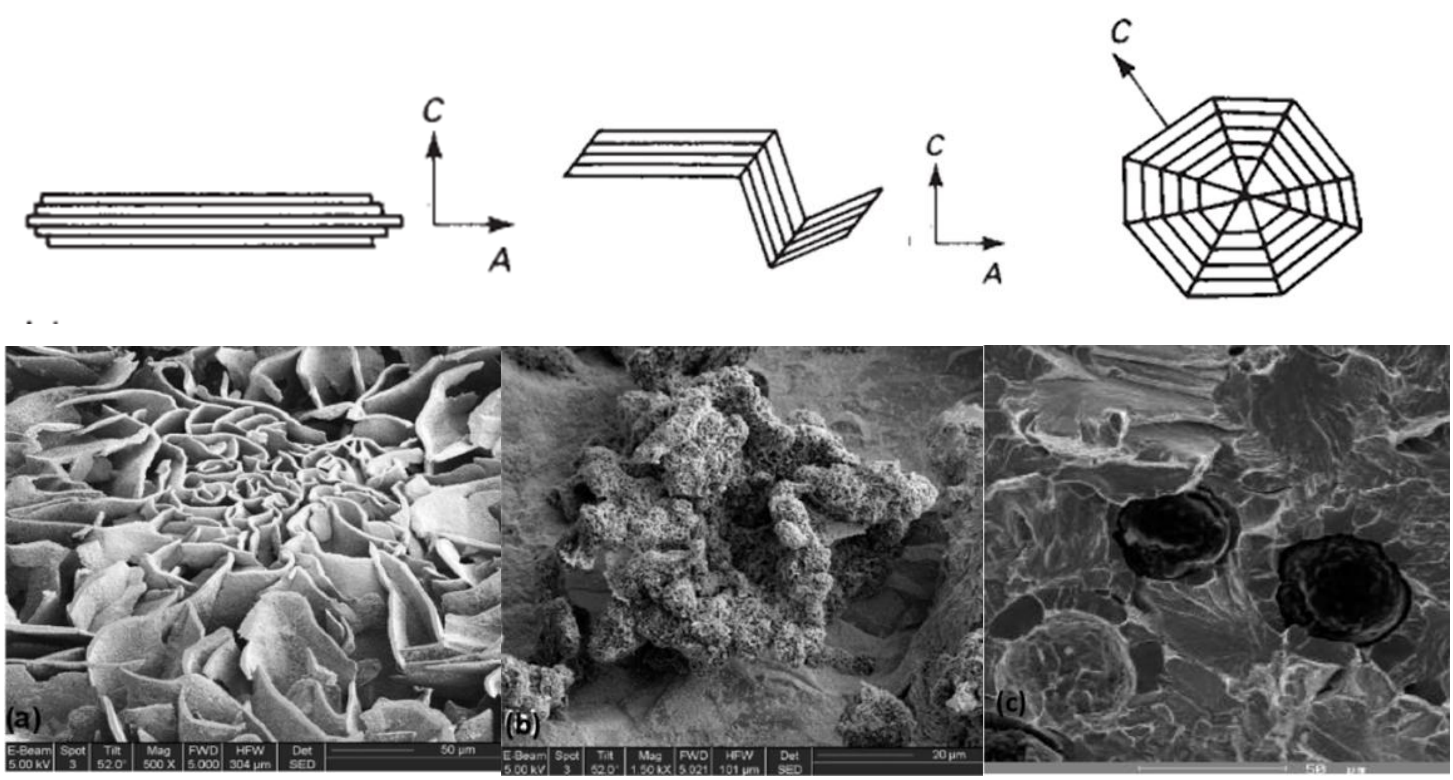

(a)

(b)

(c)

Figura 8: Ilustração esquemática de tipos de ferros fundidos com variação da morfologia da grafita, (a) floco/lamelar, (b) compacto/vermicular e (c) esferoidal/nodular. Fonte: LOHE, 2005.

\subsubsection{Ferro fundido cinzento (Floco/lamelar)}

No ferro fundido com grafitas do tipo em flocos, a direção de crescimento (A) é predominante. Assim, os planos basais são orientados paralelamente aos flocos de grafita, com base na composição química e condições de resfriamento, há cinco padrões para esse tipo de grafita lamelar designados pelas letras de A à E de acordo com a ASTM A 247 como mostrado na Figura 9 [22].

Comparado com outros modelos de grafita a principal desvantagem dessa morfologia é a resistência associada, nas quais promovem a iniciação e propagação de microfissuras por aplicação de uma tensão externa. A aresta dos flocos de grafita pode atuar como concentradores de tensões [20]. Deste modo, exibe um comportamento elástico não linear 
devido à formação destas múltiplas microfissuras nas pontas do floco, mesmo com baixas tensões fazem com que a grafita se solte da matriz metálica.

Há diversos modos para modificar a morfologia da grafita e melhorar sua resistência mecânica. Através da utilização de inoculantes apropriados é possível produzir flocos finos melhorando sua resistência incluindo a dureza, e assim podendo atender grande variedades de aplicações $[8,18,25]$.

\subsubsection{Tipos e morfologias da grafita em ferros fundidos cinzento}

Como já mencionado a ASTMA 247 [22], classifica o ferro fundido cinzento pela morfologia da grafita, identificando cinco tipos que podem ocorrer durante o resfriamento, agrupados como mostrado na Figura 9.
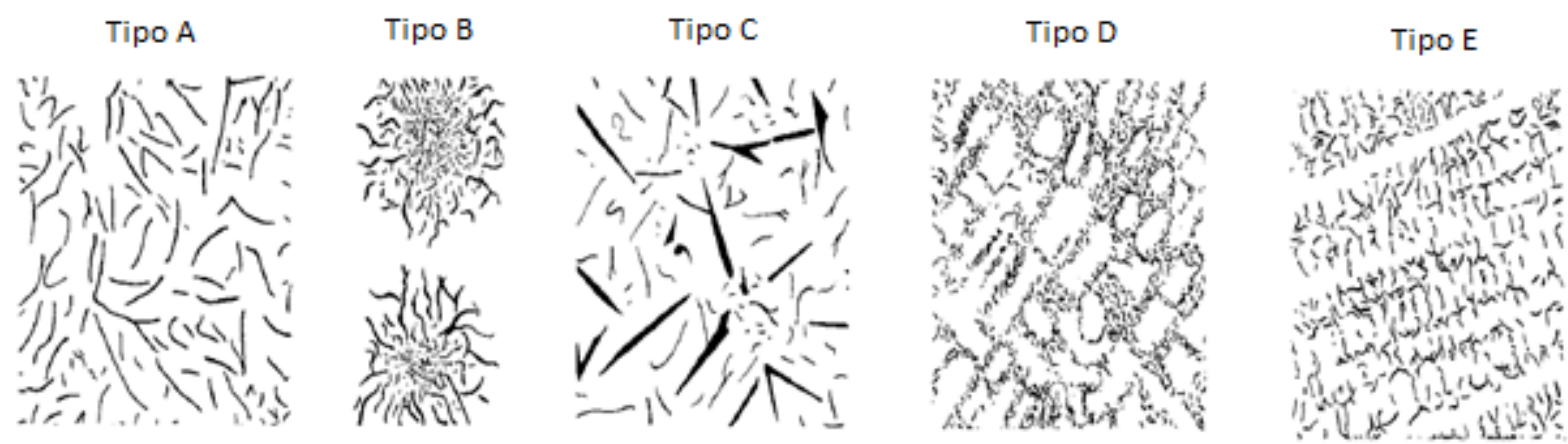

Figura 9: Tipos de morfologias encontradas nos ferros fundidos cinzentos segundo a norma ASTM 247.

Fonte: ASTMA 247.

A grafita do tipo A em orientação aleatória é o mais usado para aplicações. Em tamanhos intermediários, possui maior resistência ao desgaste, e são comumente usados em cilindros de motores.

A do tipo B, em roseta, é típico de resfriamento muito rápido, sendo comum em seções de perfil de pequena espessura.

A grafita do tipo C é típica em ferros fundidos hipereutéticos, com a característica de aumentar a resistência ao choque térmico e aumentar a condutividade térmica. As desvantagens são: diminui o módulo elástico, não ter boa resistência ao impacto e não são favoráveis para acabamentos em peças usinadas.

A grafita pequena interdendrítica do tipo D promove um acabamento usinado fino, minimizando a corrosão de superfície, mas é difícil obter matriz perlítica com esse tipo de grafita pois é formada pelo resfriamento rápido em matriz ferrítica. 
A do tipo E sendo também interdendrítica tem uma preferência em sua orientação aleatória ao contrário do tipo $\mathrm{D}$, este tipo pode ser associada com uma matriz perlítica e, assim, pode produzir uma fundição cujas propriedades de desgaste são tão boas como as do tipo A [26].

\subsubsection{Ferro fundido nodular/esferoidal}

A morfologia da grafita em forma de nódulos é obtida pelo maior teor de CE e menor teor de enxofre comparado com a grafita em flocos, o teor de silício pode variar entre 1,8 a $3 \%$, quando as boas resistências à oxidação são exigidas. No entanto, altos teores de carbono e silício favorecem a formação de nódulos, enquanto que menores quantidade desses elementos leva a formação de carbonetos em vez da grafita [18].

A austenita se forma durante a solidificação em um banho contendo silício suficiente para assegurar a formação da grafita, após a remoção cuidadosa de enxofre e oxigênio pelos inoculantes como: magnésio, cálcio entre outros elementos, que fornecem as condições necessárias para a precipitação dos átomos de carbono nos planos de cristais da grafita.

Uma escolha cuidadosa das adições de liga é usada para ajustar adequadamente a desoxidação, grafitização e nucleação destes efeitos, melhorando suas propriedades como resistência mecânica e ductilidade, significantemente melhoradas [10, 8].

\subsubsection{Grafita compactada/vermicular}

As grafitas compactadas são alongadas e orientadas como as grafitas em flocos, no entanto, eles são mais curtos e mais grossos, e bordas arredondadas, apresentando uma estrutura intermediária entre as morfologias das grafitas em flocos e em nódulos na matriz metálica [17].

Na medida em que as partículas da grafita compactada aparecem vistas em dimensões 3D em formas de verme, aferiu chamar esse material de ferro fundido vermicular, resultando em grande adesão entre a grafita e a matriz. Geralmente produzida de forma similar aos nodulares, mas com menor concentração de magnésio, acaba sendo mais complexa que os outros tipos de ferro fundido [29].

A adição de elementos inoculantes (magnésio cério), elementos de esferoidização (magnésio, cálcio ou metais de terras raras), anti-esferoidização (titânio, alumínio) dever ser bem controlada, a fim de produzir uma microestrutura contendo partículas em formas de veios [29]. 
Comumente pode ser encontrado grafitas nodulares durante toda extensão dessa microestrutura, este grau pode variar entre 1 a $20 \%$ de nodularização para melhor fluidez, desempenho de usinabilidade e resistência mecânica [17, 29].

\subsubsection{Outros tipos de ferros fundidos}

Outras variedades de ferros fundidos que podem ser obtidos são: branco, mesclado e maleável, essa classificação é dada quando o carbono está combinado em cementita, com isso acaba se obtendo uma superfície de fratura clara, diferentemente da microestrutura com a presença da grafita $[11,31]$

\subsubsection{Ferro fundido branco}

Os ferros fundidos brancos tem a característica de alta dureza e elevada resistência ao desgaste, com ductilidade muito baixa. Comumente usado onde se busca dureza e resistência muito altas sem a necessidade de ao mesmo tempo ser dúctil [31].

\subsubsection{Ferro fundido maleável}

A principal característica do ferro fundido maleável é sua ductilidade, a qual pode ultrapassar $10 \%$, por essa razão é comum dizer que é uma liga intermediaria entre o aço e o ferro fundido. Podem ocorrer microestruturas de núcleo branco e de núcleo preto [31].

\subsubsection{Ferro fundido mesclado}

A composição química do ferro fundido mesclado é intermediaria entre o ferro fundido branco e o ferro fundido cinzento, com microestruturas muito complexas ocorrendo carbonetos e grafita em sua solidificação [31].

\subsection{Inoculação}

O processo de inoculação é introduzir certos tipos de micro partículas durante o banho, fornecendo a nucleação de uma determinada fase podendo modificar seu tamanho e sua forma. No caso dos ferros fundidos, estes inoculantes são alguns elementos específicos que são ligados com o Fe-Si. Estes elementos resultam em óxidos e sulfetos de natureza homogênea ou heterogênea, fornecendo locais de nucleação ou precipitação para a grafita. 
O objetivo da inoculação é assegurar que os núcleos sejam suficientes para a cristalização da grafita no início da solidificação eutética, evitando a formação do carboneto de ferro $\left(\mathrm{Fe}_{3} \mathrm{C}\right)[10]$.

\subsection{Propriedades mecânicas e térmicas}

As propriedades dos ferros fundidos são determinadas pela forma das partículas da grafita, e também pela estrutura da matriz de ferro. A temperatura é também um parâmetro importante que afeta as propriedades mecânicas desse material. Para otimizar as propriedades de um determinado componente, é necessário avaliar se as propriedades mecânicas e térmicas vão ser satisfatória para determinado uso, portanto, uma elevada resistência mecânica deve ser acompanhada por uma baixa condutividade térmica, e vice-versa [8].

Este principal fenômeno se dá pela forma e a anisotropia da fase da grafita, que pela relação entre nodularidade e propriedades mecânicas e térmicas é apresentado na Figura 10. Como as partículas de grafita se tornam mais esféricas ocorre aumento da força e rigidez, acompanhado de perda na condutividade térmica e de amortecimento. Por outro lado pouca porcentagem de nodularidade apresenta propriedades mecânica inferiores, porém com melhor condutividade térmica $[8,19]$.

O ferro fundido de grafita compactada é um material ideal quando de ambas as propriedades mecânica e térmica são necessarias. A influência da temperatura sobre as propriedades mecânicas tem sido avaliada por muitos pesquisadores [8, 19, 21, 32, 33]. No geral, as propriedades mecânicas dos ferros fundidos podem deteriorar-se com o aumento da temperatura, o que impede aplicações em temperaturas elevadas, devido a interconexão de suas partículas de grafita e, consequentemente as taxas de oxidação e propagação de trincas. 


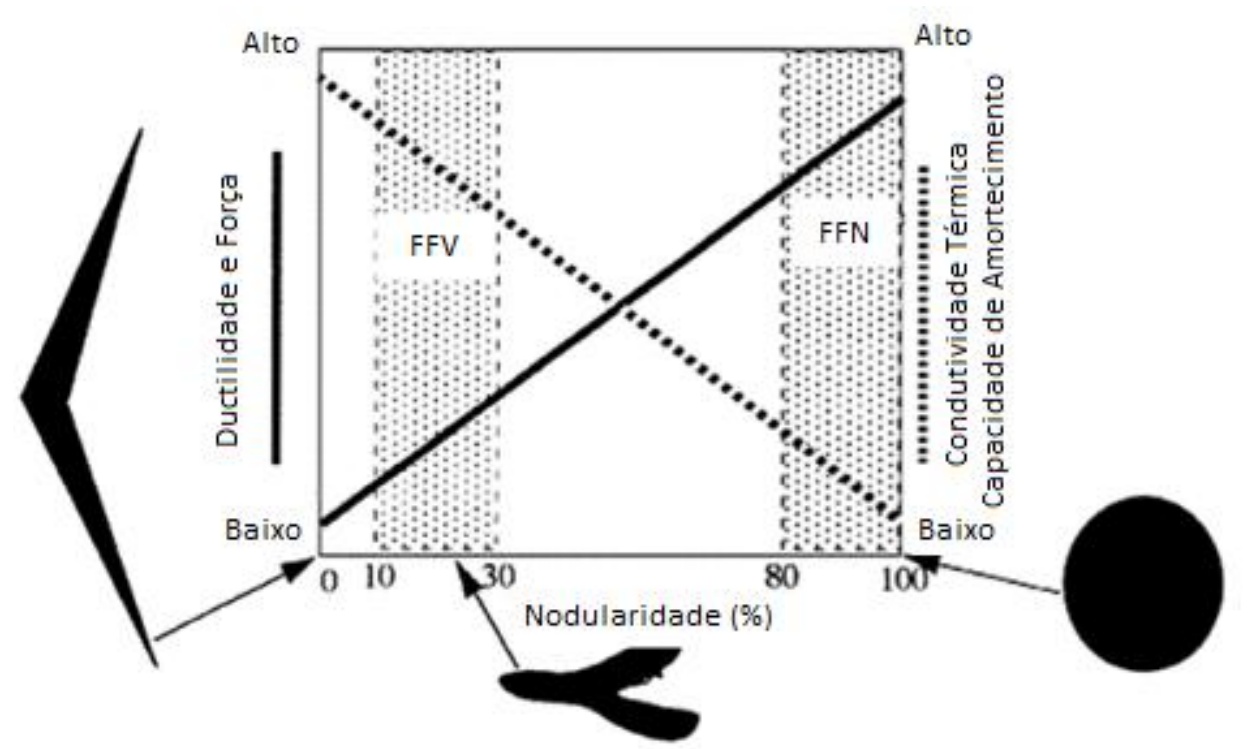

Figura 10: Variação de propriedades mecânicas e térmicas em função da porcentagem de nódulos.

Fonte: Adaptado de RUNDMAN, 2008.

\subsection{Introdução à fadiga termomecânica}

O fenômeno da fadiga é uma área de pesquisa muito importante dentro do campo de ciência e engenharia de materiais, sabe-se que a fadiga é responsável por pelo menos $90 \%$ de todas as falhas mecânicas. Brooks e Choudhury [36] indicavam que $61 \%$ das falhas de aeronaves são causada por fadiga, ao passo que outras falhas incluem sobrecarga $18 \%$, por corrosão sob tensão $8 \%$, desgaste excessivo 7\%, corrosão, oxidação a alta temperatura 5\% e de tensão de ruptura $1 \%$.

A fadiga é considerada como resultante de uma carga ciclicamente aplicada sobre um material, que mostra um gradiente de taxa de crescimentos trinca, sendo uma resposta até a falha final. Esta forma de fadiga mecânica não dá uma imagem completa do desempenho do material em aplicações que envolvem gradientes de temperatura.

Em geral, dependendo do nível de tensão e deformação que se envolve, pode se classificar comumente três formas conhecidas de fadiga:

$\begin{array}{ll}\checkmark & \text { Fadiga de alto ciclo (FAC) } \\ \checkmark & \text { Fadiga de baixo ciclo (FBC) } \\ \checkmark & \text { Fadiga termomecânica (FTM) }\end{array}$

FAC é associada a baixos níveis de tensão e corresponde a baixa amplitude de deformação elástica e um elevado número de ciclos até a falha. Na FBC a tensão excede o intervalo de deformação elástica e provoca a deformação plástica, de modo que o material 
apresenta um número relativamente baixo de ciclos até a falha. A FTM é muitas vezes considerada uma subcategoria da FBC, principalmente por causa da presença de deformações plásticas durante números relativamente baixo de ciclos [37].

A FTM é causada por tensões e deformações que se desenvolvem durante as mudanças, sendo elas, de temperatura ou cargas mecânicas. Se as tensões de um componente se desenvolvem sob a deformação térmica sem restrições, é usado o termo fadiga térmica (FT) ou fadiga de deformação térmica [24].

Uma distinção pode ser feita com a fadiga isotérmica (FI), isto é, cíclica, aplicando uma tensão com a temperatura constante. Na maioria dos casos os testes não captam todos os mecanismos de danos que ocorrem na deformação-tempo nas condições de temperatura em FTM. Assim, FTM pode ser mais prejudicial comparado com FI, na temperatura máxima de operação [38].

A principal diferença entre FTM e FI é a restrição, quando uma estrutura aquece e se desenvolve em um gradiente térmico, ela se expande [24]. Essa expansão pode causar concentradores de tensões, pois esta deformação térmica é convertida em uma deformação mecânica, na qual pode danificar a estrutura $[38,35]$.

A FTM se tornou um grande desafio para a indústria automobilística, especialmente em projetos de motores com componentes feitos de ferro fundido, devido ao fato de que esse material oferece um excelente equilíbrio entre as propriedades mecânicas e térmicas. Estes componentes são expostos durante longos períodos de tempo, em elevadas temperaturas, a cerca de $450{ }^{\circ} \mathrm{C}$ e submetidos a um grande número de ciclos de aquecimento e resfriamento [24]. Como resultados destes ciclos, as propriedades mecânicas e térmicas do material induzem a aceleração de danos por fadiga, que pode levar a micro trincas localizadas devido a pressões que se desenvolvem como resultado da incompatibilidade de gradientes térmicos $[24,38]$.

\subsection{Fenômeno da fadiga termomecânica em motores}

O fenômeno da FTM em motores de combustão interna está relacionado com o ato de ligar e desligar, e também as grandes mudanças de carga ou modo de operação. Cabeças de cilindros, válvulas e área de saída e entrada de calor, são severamente submetidos ao chamado carregamento FTM fora de fase, onde o material está sob uma tensão de tração máxima a uma temperatura mínima do ciclo e vice-versa, como mostra a Figura 11 b. Outro tipo conhecido 
de FTM é em fase de carregamento, em que o material está sob uma tensão de tração máxima à uma temperatura máxima durante o ciclo [39].

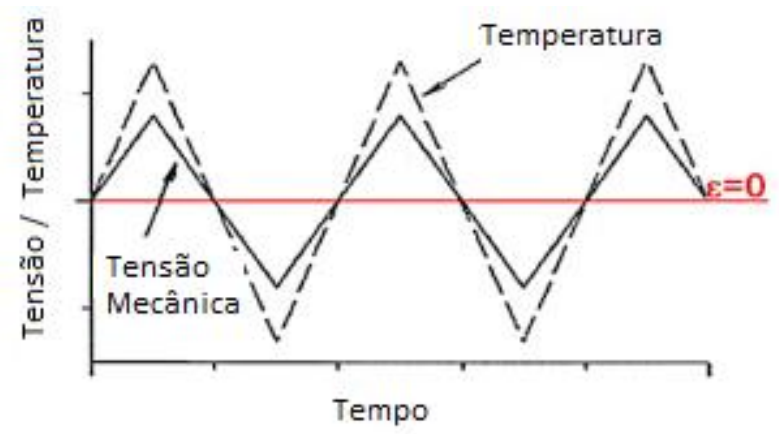

(a)

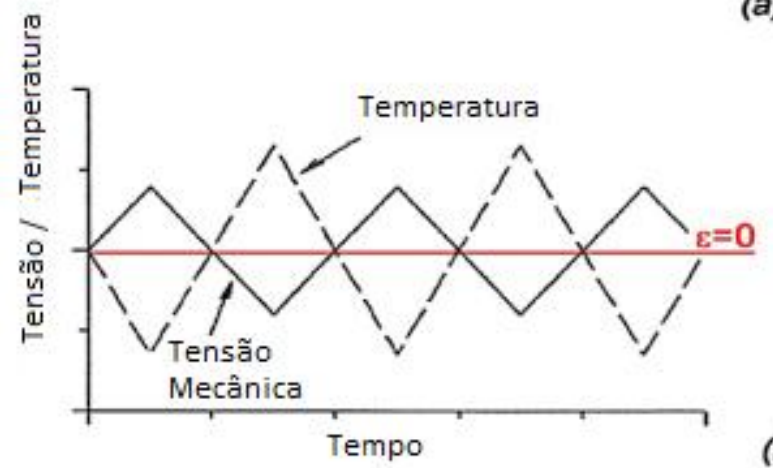

(b)
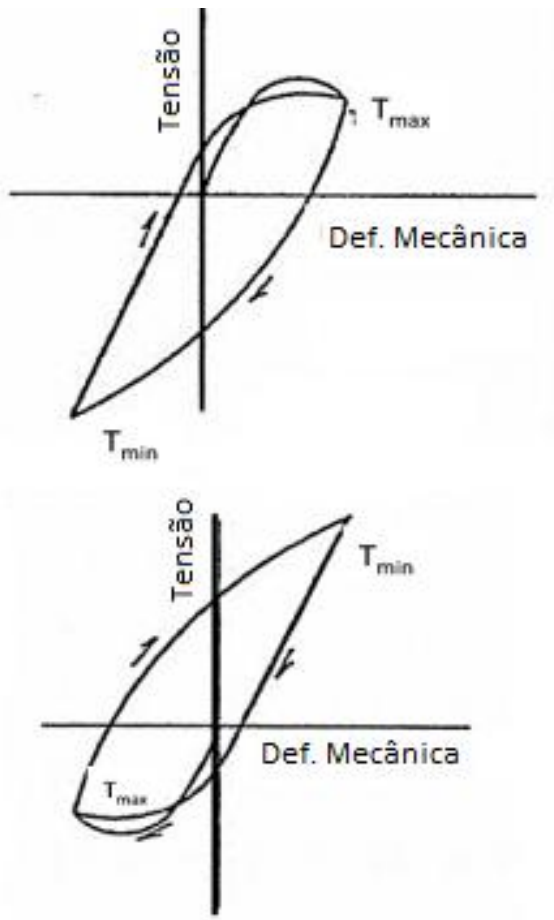

Figura 11: Tensão mecânica e variação de temperatura na FTM, em conjunto com resposta tensão-deformação. (a) carregamento FTM em fase, (b) carregamento FTM fora de fase. Fonte: Adaptado de TRAMPERT, 2008.

\subsection{Mecanismos e danos nos ferros fundidos sob FTM}

O estudo fundamental em monocristais tem mostrado que a altas temperaturas, fissuras causadas pela fadiga em planos de deslizamentos persistem na sua superfície, a iniciação da trinca pode ocorrer em materiais policristalinos da mesma forma, se não iniciada por inclusões ou outras fases presentes [24, 34].

Se a superfície da amostra é lisa, extrusões e intrusões poderão ser observadas após cargas cíclicas e também rachaduras iniciadas ao longo da faixa de deslizamento. $\mathrm{O}$ deslizamento em locais de extrusões desenvolve-se no plano da tensão máxima de cisalhamento, $45^{\circ}$ do sentido do carregamento. O primeiro estágio do crescimento da trinca é conhecido como fase de abertura. Após o início, as extrusões e intrusões, basicamente se torna concentrações de tensão a partir de uma trinca que possa crescer a um tamanho macroscópico. 
Durante o crescimento da trinca, o mecanismo prejudicial é localizado na ponta da trinca. Dentro desta zona plástica, a trinca pode crescer em certa quantidade a cada ciclo [34].

Estas trincas por fadiga tipicamente crescem no plano perpendicular a máxima tensão, podendo levar a uma trinca instável, ou seja, ruptura do componente. No caso do ferro fundido a fase de nucleação de trinca é reduzida devido à presença de partículas de grafita, pois as concentrações de tensão se tornam inerentes . Ambos mecanismos de danos mecânicos e de oxidação são dependentes da temperatura e do tempo [36, 40].

A deformação de fluência deve ser considerada em temperaturas a partir de cerca de $40 \%$ do ponto de fusão. No entanto é possível relatar que os ferros fundidos em condições FTM submetem o prazo de relaxamento de tensão em períodos muito baixo, de ordem de apenas alguns minutos [37]. Isto leva ao caso específico da FTM em condições totais de restrição, demonstrando relaxamento durante a parte de compressão num ciclo e provocando uma deformação plástica maior na parte subsequente a tração durante o ciclo.

Tensões de tração crescentes devido ao relaxamento das tensões em compressão são desenvolvidas numa operação real do motor explicado na Figura 12. Este aumento de deformação em tensão é considerado para induzir danos, e consequentemente, reduzir o tempo de vida.

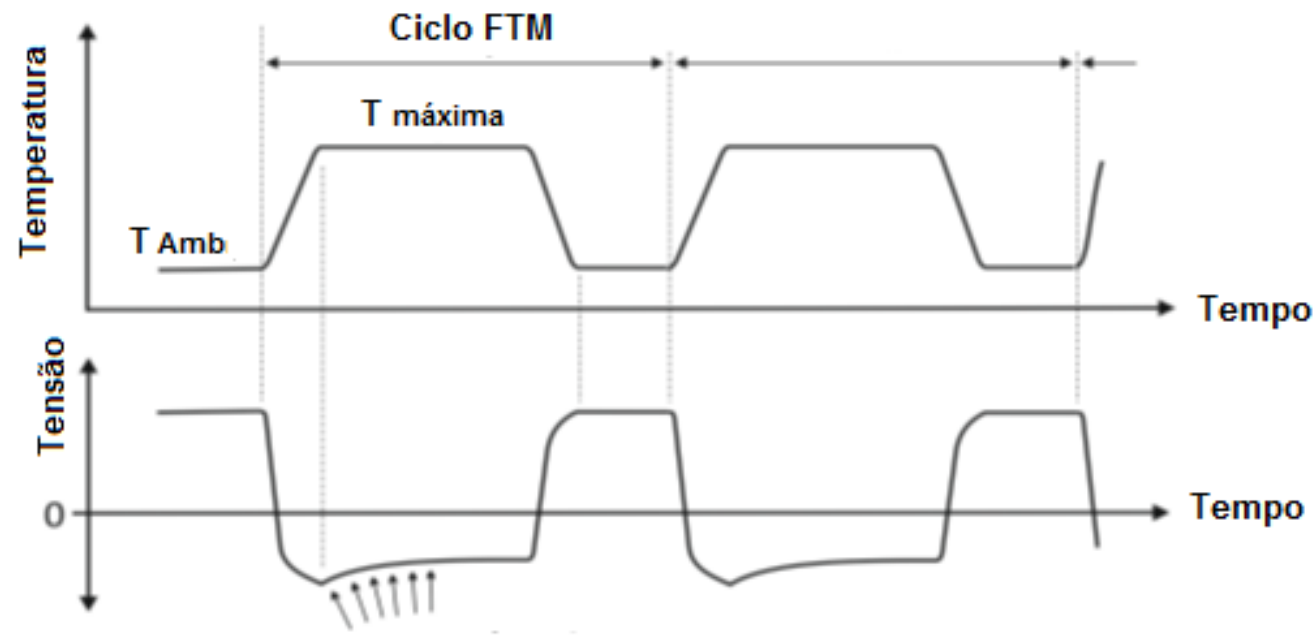

Relaxação de tensão

Figura 12: Carregamento esquemático da FTM mostrando tensões de compressão durante o aquecimento, relaxação de tensão durante o patamar em alta temperatura e tensão residual durante o resfriamento.

Fonte: Adaptado de GHODRAT, 2013.

Quando o motor é ligado à temperatura sobe e tensões de compressão se desenvolvem, uma vez que a temperatura de operação é alcançada, pode ocorrer deformação elástica ou 
plástica dependendo da temperatura e tempo, vão se desenvolver seguido de deformação de relaxamento durante a temperatura elevada. No final do tempo de funcionamento, ou seja, quando o motor e desligado se resfriam até a temperatura ambiente, este resfriamento produz tensões de tração residual, que levam a deformação plástica [41].

A repetição de ciclos no ato de liga-desliga, durante a vida operacional do motor, pode produzir trincas por FTM, especialmente nas regiões mais finas do motor como na válvula e cabeça do cilindro.

Como já comentado anteriormente a trinca pode ocorrer como extrusões nos planos de deslizamento e intrusões internas, que é devido a absorção de átomos de oxigênio nos planos de deslizamento expostos.

Ocorrem dois tipos de oxidação nos ferros fundidos: metálica, onde ocorre o ganho de massa obtido pela formação de camadas de oxido metálico, e a oxidação de carbono, que se conduz na descarbonetação onde acontece a perda de massa [42].

As camadas de óxido de ferro que se desenvolvem a elevadas temperaturas, são frágeis e auxiliam as trincas já existentes em criar caminhos para facilitar o acesso do oxigênio no material.

\subsection{Degradação microestrutural durante FTM}

A degradação microestrutural também pode ocorrer sob condições em FTM. Como o material torna-se instável durante o período em altas temperaturas pode ocorrer o engrossamento de grãos, precipitação de uma segunda fase, grafitização do carboneto em perlita, superenvelhecimento, segregação dos grãos e oxidação da perlita na grafita [40].

Como discutido, as partículas de grafita atuam diretamente na deformação do material, podendo enfraquecer através da diminuição da rigidez em tração. Uma vez que se solta da matriz metálica, trincas podem se propagar, porém, em compressão estas micro trincas estão fechadas e existe uma maior rigidez, isto leva a um comportamento de tensão-compressão assimétrica em ferros fundidos [44]. 


\section{MATERIAIS E MÉTODOS}

A Figura 12 apresenta o fluxograma do desenvolvimento deste trabalho ilustrando as etapas a serem realizadas.

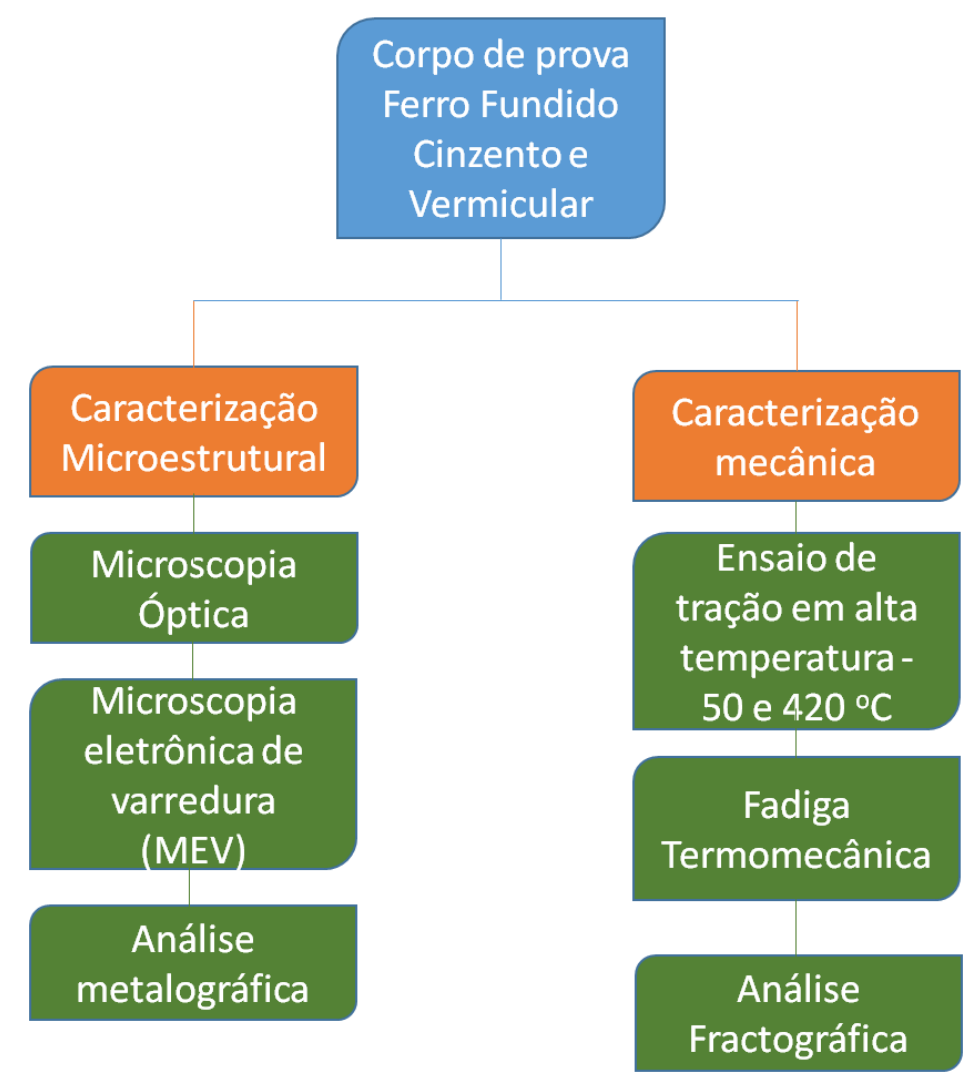

Figura 13: Fluxograma dos experimentos a serem executados.

Fonte: Produção do próprio autor.

\subsection{Material}

Neste trabalho, foram estudados dois tipos de ferros fundidos, sendo um cinzento e outro vermicular, produzidos pela empresa TUPY S.A, localizada em Joinville, SC, Brasil. Estes materiais são aplicados para a fabricação de blocos e cabeçotes de motores automotivos.

Na Figura 15 é mostrado um bloco em formato Y norma ASTM A476/476M [45], para retirada das amostras para confecção dos corpos de prova no estado bruto de solidificação.

Após retirada das amostras, estas foram usinadas para obtenção dos corpos de prova de tração e fadiga termomecânica, com os dois passos de usinagem finais de torneamento com remoção de 0,05 mm, para evitar tensões internas perto da superfície, isto resultou numa média de valor de rugosidade de cerca de $0,6 \mu \mathrm{m}$. 
A análise química dos materiais estudados foi realizada pela empresa fornecedora TUPY, e estão de acordo com exigências seguidas pela norma ASTM A48/A48M-16 [46].

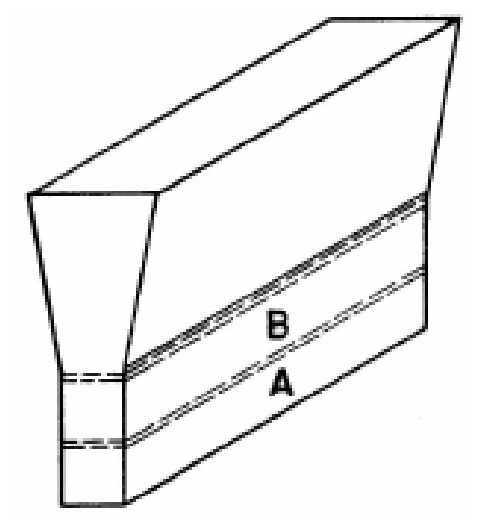

Figura 14: Bloco "Y" segundo a norma ASTM A476/476M [45]. Fonte: ASTM A476/476M.

\subsection{Métodos}

\subsubsection{Ensaio de tração}

Os ensaios de tração foram realizados em um equipamento da marca MTS, modelo 810, com capacidade de $250 \mathrm{KN}$. Este sistema possui garras especiais de superliga de Ni e forno indutivo de alta frequência com bobinas de cobre para aquecimento dos corpos de prova. Os ensaios de tração foram executados conforme a metodologia, para ensaios de tração de materiais metálicos em temperaturas ambiente e elevadas, respectivamente das normas ASTM E8M/14 [48] e ASTM E21 [47].

Assim, os corpos de provas para ensaio de tração foram primeiramente aquecidos em temperaturas de 50 e $420{ }^{\circ} \mathrm{C}$, com tempo de encharque de $5 \mathrm{~min}$. sendo imediatamente ensaiados a uma taxa de $1,6 \times 10^{-2} \mathrm{~s}^{-1}$. A deformação axial foi medida pelo uso de um extensômetro para altas temperaturas (até $1200{ }^{\circ} \mathrm{C}$ ), com hastes cerâmicas, e tendo comprimento útil de $12 \mathrm{~mm}$.

Foram ensaiados 10 corpos de prova, para os dois materiais em estudo, sendo obtidos os valores da tensão limite de escoamento, tensão limite de resistência, deformação total e módulo elástico, obtido pela secante a $0,2 \%$ de deformação total.

A Figura 16 apresenta a geometria e dimensões do corpo de prova confeccionadas conforme orientação da norma técnica ASTM E8M/14 [48]. 


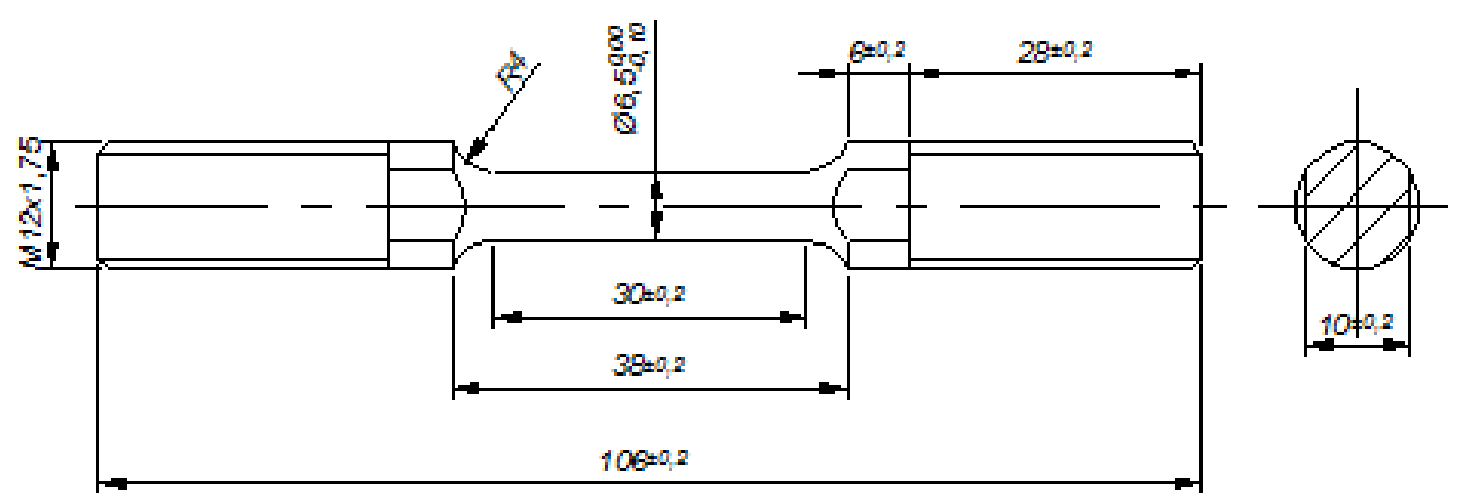

Figura 15: Geometria e dimensões do corpo de prova utilizado no ensaio de tração nas temperaturas de $50^{\circ} \mathrm{C}$ e $420^{\circ} \mathrm{C} \mathrm{[48].}$

Fonte: ASTM E8M/14.

\subsubsection{Microscopia óptica (MO)}

A preparação do material para análise metalografica foi realizada conforme a norma ASTM E3-11, sendo que as amostras foram retiradas dos blocos $\mathrm{Y}$ e dos corpos de provas do ensaio de FTM após ensaio. Estas amostras foram posteriormente embutidas em baquelite, lixadas com lixas de grama 220, 320, 400, 600 e 1000, seguido de polimento em pasta de diamante de granulação $9 \mu \mathrm{m}, 3 \mu \mathrm{m}$ e $1 \mu \mathrm{m}$ e em seguida com alumina de tamanho médio de $0,3 \mu \mathrm{m}$.

Para avaliação dos tipos de ferro fundido (morfologia das grafitas) as amostras foram analisadas primeiramente sem ataque, sendo posteriormente a microestrutura revelada pelo uso de uma solução de ácido Nítrico 2\% + etanol 98\%), denominado de Nital 2\%, aplicada por um tempo de aproximadamente $4 \mathrm{~s}$.

Para as análises metalograficas quantitativas, foi utilizado um microscópio óptico da marca ZEISS modelo LAB. A1 equipado com uma câmera da marca AXIO modelo ERC5s e pelo uso do programa AXIO VISION Rel. 4.8 em aumentos de 100,200, 500 e 1000 vezes.

\subsubsection{Microscopia eletrônica de varredura (MEV)}

Após o ensaio de fadiga termomecânica a superfície de fratura foi analisada por meio de um microscópio eletrônico de varredura da marca FEI® modelo Inspect F-50 pertencente ao SMM-EESC-USP para verificação da morfologia e identificação dos micromecanismos de fratura. 


\subsubsection{Ensaio de fadiga termomecânica}

\subsubsection{Corpo de prova}

Para a realização do ensaio de fadiga termomecânica foi utilizado corpos de prova com dimensões e geometria seguido da norma ASTM E8M/14 [48], mostrado na Figura 17.

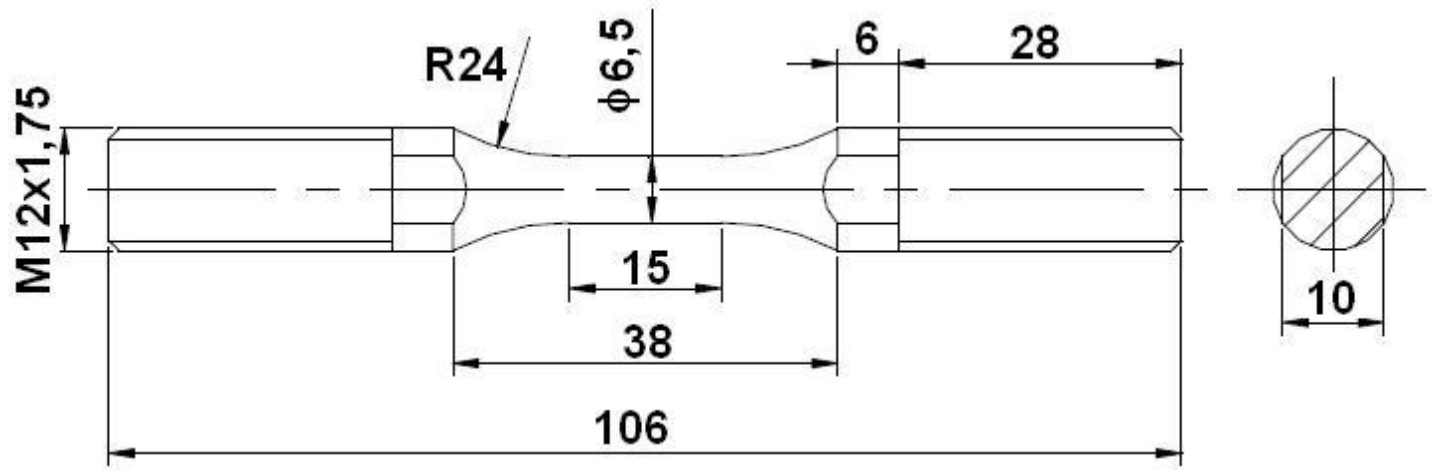

Figura 16: Dimensões do corpo de prova utilizado para o ensaio de FTM.

Fonte: ASTM E8M/14.

\subsubsection{Procedimento do ensaio FTM}

Os testes por FTM foram projetados para representar as condições que mais se aproximam daquelas que o componente motor de combustão interna esta submetido quando em operação, mais precisamente nas regiões das válvulas e das cabeças dos cilindros. Portanto, estes testes foram realizados em controle de deformação, sob-restrição total $\left(\varepsilon_{\text {total }}=\right.$ 0), o que significa que a tensão total medida pelo extensômetro foi mantida constante com a referência de $50{ }^{\circ} \mathrm{C}$, e a temperatura do ensaio variada entre $50{ }^{\circ} \mathrm{C}$ e $420{ }^{\circ} \mathrm{C}$, e tempo de patamar definido em 180 segundos [28]. As equações aplicadas durante o carregamento por FTM são apresentados na equação (1) [7].

$$
\varepsilon_{\text {total }}=\varepsilon_{e l .}+\varepsilon_{p l .}+\varepsilon_{t e r}
$$

Onde, $\varepsilon_{\text {total }}$ é a medida de deformação do extensômetro, $\varepsilon_{e l}$. a deformação elástica calculada utilizando o módulo de Young na temperatura desejada, E(T), equação (2). Os valores de $\mathrm{E}(\mathrm{T})$ foram obtidos a partir de um gráfico $\mathrm{E} \times \mathrm{T}$ obtidos dos ensaios de tração. A deformação térmica $\varepsilon_{\text {ter. }}$ foi calculada pela equação (4), com $\alpha$ sendo o coeficiente de 
dilatação térmica linear do material, sendo calculado a partir de medições da deformação durante o aquecimento em expansão livre, ou seja, em controle de força e com $\mathrm{F}=0$, essa medição foi realizada para cada corpo de prova antes de ser realizado o ensaio de FTM. $\Delta T$ sendo a diferença entre as temperaturas em duas situações: ambiente e $50{ }^{\circ} \mathrm{C}$ e ambiente e 420 ${ }^{\circ} \mathrm{C}$. O resultado de deformação plástica é conhecido pela subtração da deformação elástica e a térmica pela deformação total como mostrado na equação (3).

$$
\begin{gathered}
\varepsilon_{e l .}=\frac{\sigma}{E(T)} \\
\varepsilon_{p l .=} \varepsilon_{\text {total }-} \varepsilon_{\text {el. }-} \alpha \Delta T \\
\varepsilon_{\text {ter. }}=\alpha \Delta T
\end{gathered}
$$
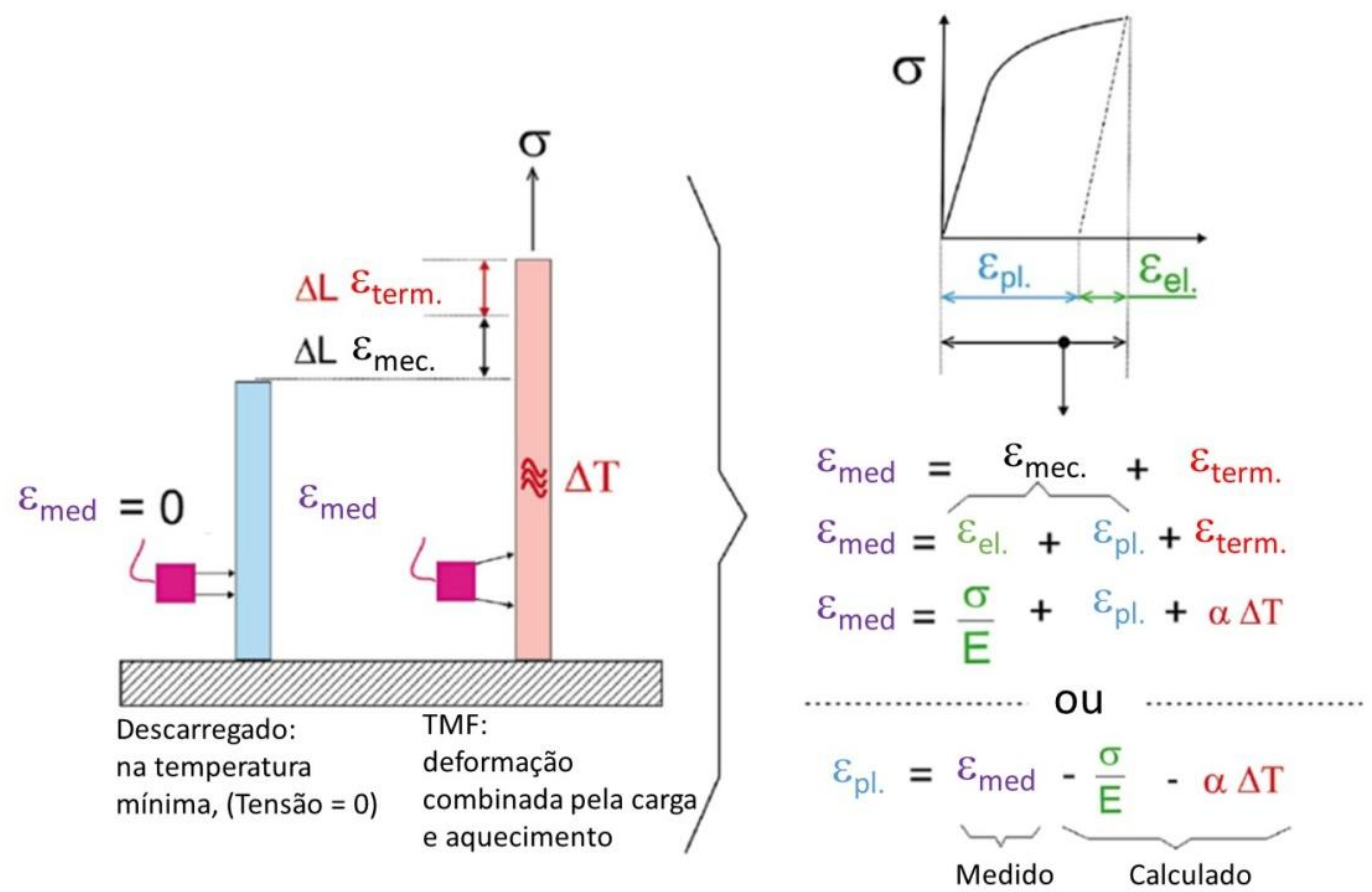

Figura 17: Equações básicas para tensões induzidas durante o ensaio de FTM.

Fonte: Adaptado de GHODRAT, 2013.

\subsubsection{O ensaio de fadiga termomecânica}

As etapas dos ciclos térmicos foram baseadas nas máximas taxas de aquecimento e resfriamento, sendo o tempo de patamar o mínimo suficiente para causar os efeitos deletérios 
do aquecimento nos componentes bloco e cabeçote dos motores. Sendo assim, as taxas de aquecimento e de resfriamento foram de $9{ }^{\circ} \mathrm{C} / \mathrm{s}$ e $6{ }^{\circ} \mathrm{C} / \mathrm{s}$ (o máximo conseguido pelo sistema de aquecimento e resfriamento respectivamente) e $180 \mathrm{~s}$ de patamar "dwell" [28]. Este procedimento de ensaio será referido como procedimento padrão.

No início do ensaio, em controle de força, a carga é inicialmente mantida em zero enquanto a temperatura do corpo de prova é elevada até $50^{\circ} \mathrm{C}$, permitindo a expansão livre do extensômetro e o comprimento útil nesta temperatura é a referência para a medida das deformações durante o ensaio. Ainda em controle de força, são realizados 05 ciclos térmicos para estabilização do sistema de ensaio com relação à temperatura no corpo de prova e garras.

Após a estabilidade do sistema o ensaio de FTM é iniciado, sendo registrados os valores de temperatura, força e deslocamento do pistão hidráulico (COD). Na Figura 19 é possível ver o fenômeno e o procedimento do ciclo térmico aplicado.

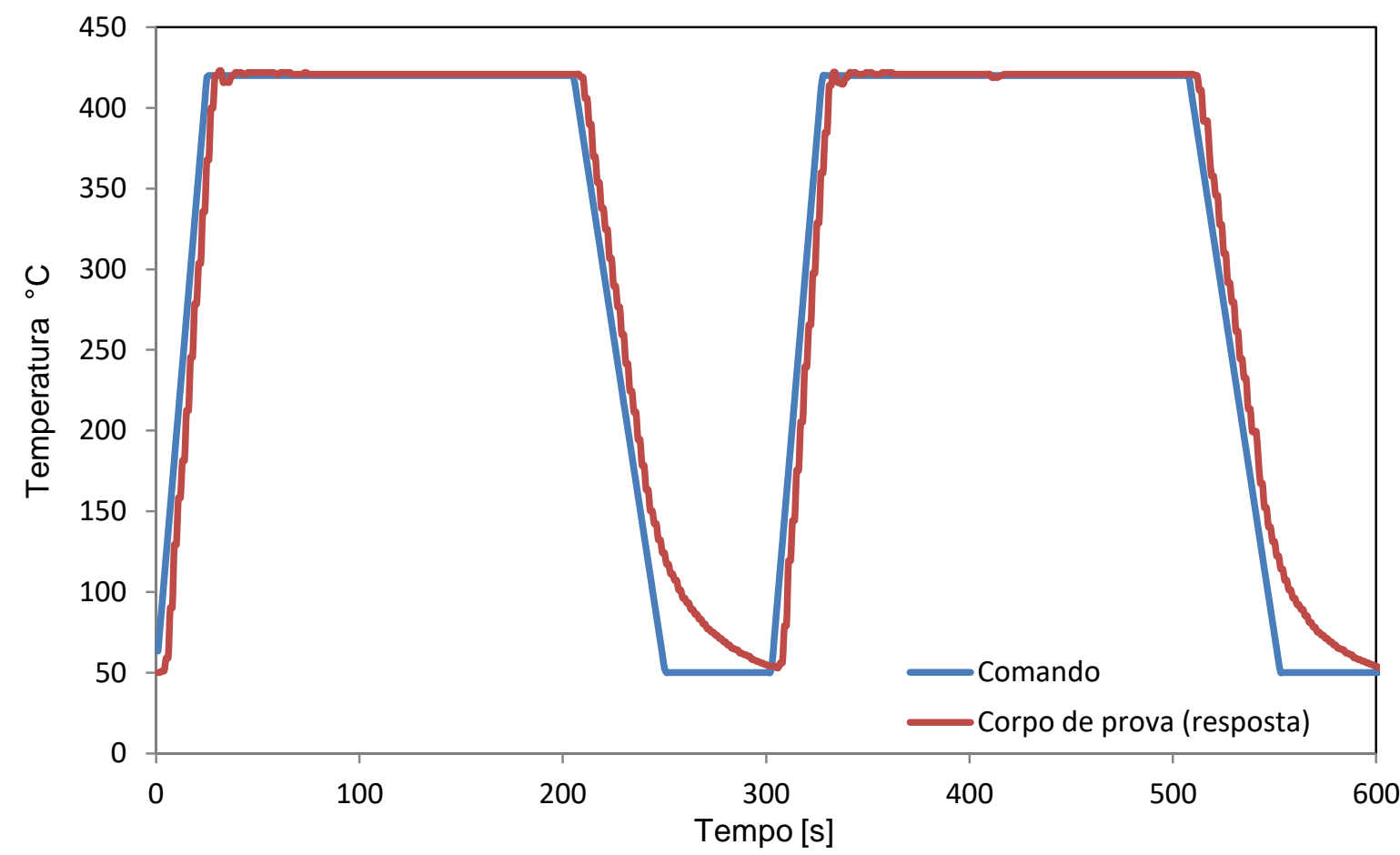

Figura 18: Modo de ensaio aplicado em FTM onde podem ser observadas as temperaturas do comando e resposta.

Fonte: Produção do próprio autor.

Para o ensaio de FTM uma programação de teste foi criada, onde todo sistema mecânico desenvolvido pela máquina é controlado computacionalmente. O software é incorporado para projetar e monitorar as ações de comando em controle de carga, deslocamento e pela deformação. 
Estes comandos podem ser ativados apenas um por vez, sendo que a temperatura e o resfriamento podem ser controlados independentemente utilizando o software "Multiple Purpose Testing" (MPT). Este estabelece um ciclo de rotina que é muito importante para que haja um bom controle, isto implica que, todo o ensaio tenha o mesmo ajuste e procedimentos executados para todos os corpos de prova.

O programa MPT propõe um ambiente de programação de gráficos, que permite definir segmentos diferentes tais como, processos de aquisição de dados e de iniciação do ensaio, usados para definir um conjunto de ações sequenciais a serem realizadas.

Um procedimento analítico para o ensaio de FTM foi configurado seguindo alguns critérios pré-estabelecidos, na qual o procedimento começa com ativação dos limites de aquisição de dados, e ao atingir o limite de segurança o ensaio é interrompido.

Antes do inicio de cada ensaio foi realizado um teste de expansão térmica em todos os corpos de prova. A leitura do extensômetro inicial $\left(l_{0}\right)$ foi informada servindo como ponto de partida para a verificação da expansão térmica nas temperaturas de 50 e $420^{\circ} \mathrm{C}$, mantido em controle de carga zero.

A carga é mantida zero, porque, geralmente algum nível pequeno de tensão pode ser encontrado durante a montagem do corpo de prova. Depois de realizados os critérios mencionados a temperatura do corpo de prova foi ajustado para $50^{\circ} \mathrm{C}$ em expansão livre, deste modo o comando foi trocado de controle de carga para deformação, na qual o extensômetro foi mantido constante em zero.

Este procedimento destina-se em manter os testes de FTM em condições bem definidas, servindo como um ponto de referência para todos os testes.

Em geral, a repetição dos procedimentos idênticos pode ser realizada usando bloco de rotina, através do software MPT, ou seja, procedimento de grupo, que são incorporadas durante o teste de FTM.

O equipamento pode ser controlada também com o comando manual, que permite o operador inserir valores de carga, níveis de deslocamento ou deformação. Assim, foi utilizado o comando manual para o ajuste e posição dos corpos de prova, a fim de serem colocados corretamente e alinhado nas garras.

O ciclo térmico para este trabalho consiste em três etapas sucessivamente que estão incluídos em um procedimento de um grupo mostrado na Figura 20, estas etapas são:

- O corpo de prova foi aquecido através do aumento linear da temperatura de $50^{\circ} \mathrm{C}$ a $420^{\circ} \mathrm{C}$ em uma taxa de $13{ }^{\circ} \mathrm{C} / \mathrm{s}$. 
- A temperatura de patamar de $420^{\circ} \mathrm{C}$ foi mantida por 180 segundos, permitindo homogeneizar toda a área útil do corpo de prova;

- O corpo de prova é resfriado para a temperatura inicial de $50^{\circ} \mathrm{C}$ em 90 segundos e se inicia novamente o ciclo. $\mathrm{O}$ ar que fornece a capacidade de refrigeração suficiente é mantido constante durante todo o ensaio.

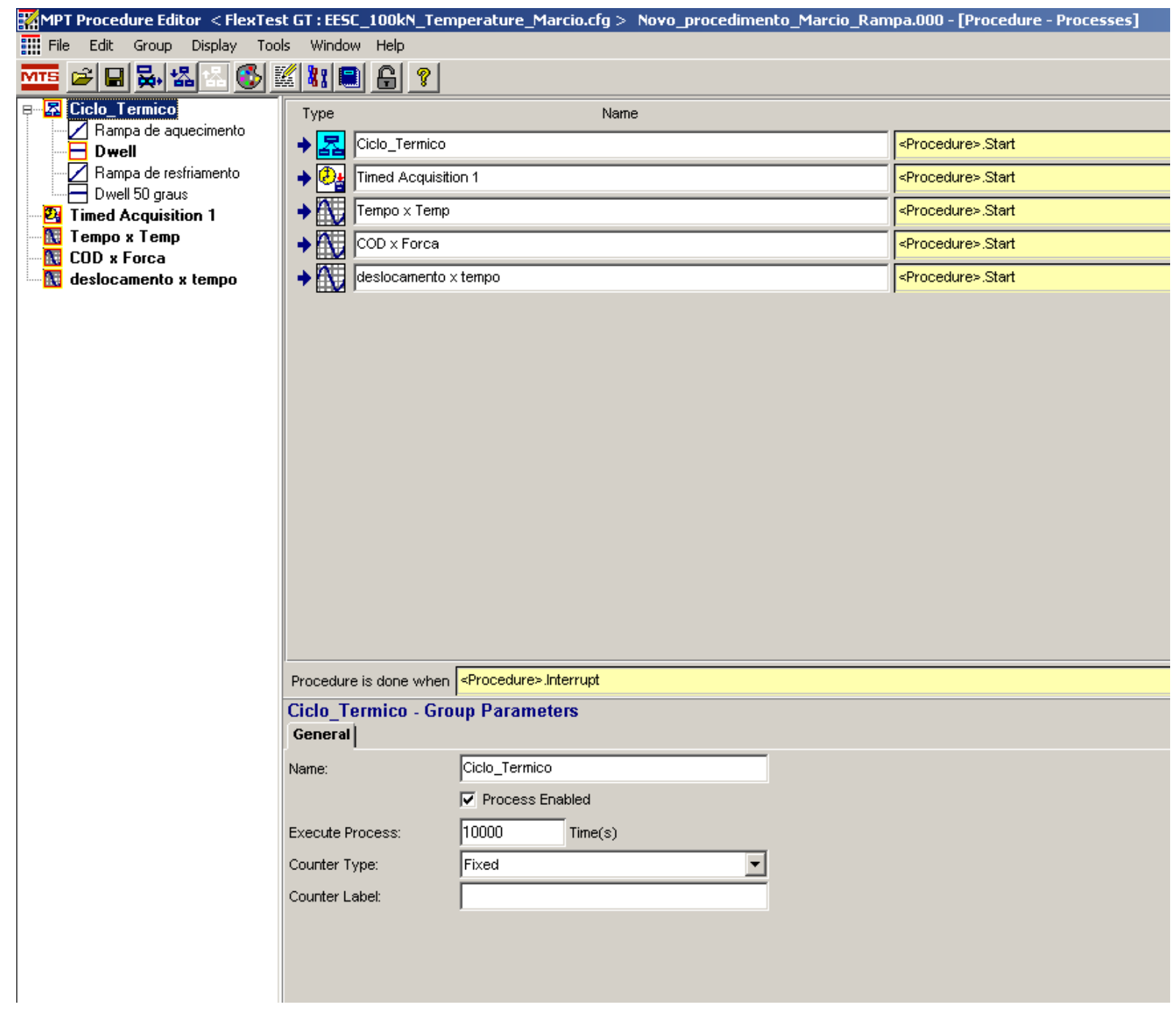

Figura 19: Configuração do software MPT para a realização do ensaio de FTM.

Fonte: Produção do próprio autor.

\subsubsection{O equipamento de FTM}

O sistema de aquecimento utilizado para o ensaio consiste em um forno indutivo com $200 \mathrm{kHz}$ de frequência e 7,5 kW de potência da marca INDUCTOHEAT, conectado a um controlador programável de temperatura do tipo EUROTHERM. O aquecimento é realizado por uma bobina de cobre com filamento tubular de $5 \mathrm{~mm}$ de diâmetro refrigerada a água, 
projetada para promover uma temperatura homogênea na secção útil do corpo de prova, contendo espaços na espiral permitindo a entrada da haste cerâmica do extensômetro a ser acoplado a área útil do corpo de prova.

O sistema de resfriamento das garras é constituído de 2 bobinas refrigerantes (C) e por um soprador de ar (A), como mostrado na Figura 20.

A deformação axial foi medida utilizando um extensômetro marca MTS modelo 632.54F-14 (E), desenvolvido para medição de deformações em temperaturas (até $1200^{\circ} \mathrm{C}$ ), sendo equipado com hastes cerâmicas de contato, comprimento útil de $12 \pm 2,4 \mathrm{~mm}$.

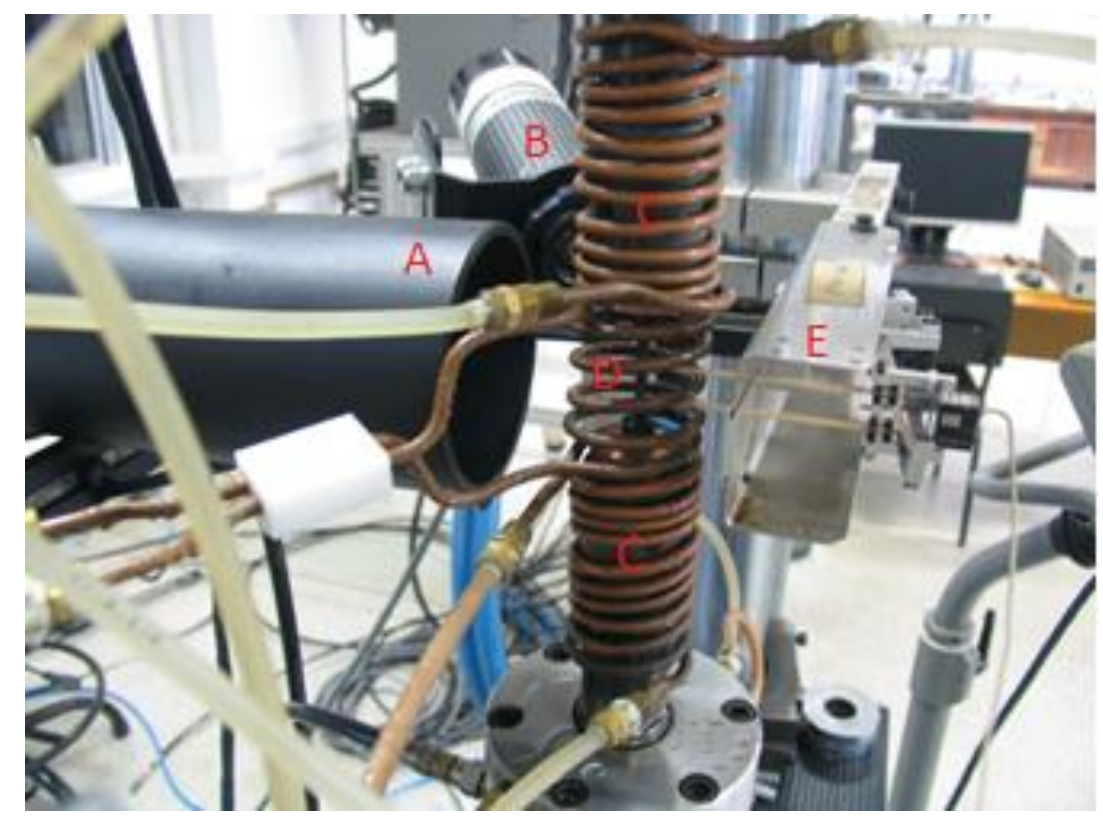

Figura 20: Máquina de ensaio MTS com (A) tubo de ventilação, (B) pirômetro, (C) garras refrigeradas, (D) espira de aquecimento por indução e (E) extensômetro para alta temperatura. Fonte: Produção do próprio autor.

\subsubsection{Controle da temperatura durante o ensaio de FTM}

A medição da temperatura no corpo de prova durante o ensaio foi realizada por um pirômetro ótico infravermelho com mira a laser, marca RAYTEK modelo RAYSXSMTCF $1 \mathrm{~L} 2$, em uma faixa de temperatura de $-18^{\circ} \mathrm{C}$ a $500^{\circ} \mathrm{C} \pm 2^{\circ} \mathrm{C}$. Ainda que o pirômetro foi previamente calibrado, necessitou da garantia de uma temperatura homogênea na seção calibrada do CP. Para tanto, foram realizados ensaios utilizando termopares do tipo $\mathrm{K}$ (Crhomel-Alumel) soldados em três pontos da área útil de um corpo de prova, regularmente utilizado para verificação da temperatura, Figura 21. 
Um termopar foi colocado no centro da área útil e os outros dois posicionados $5 \mathrm{~mm}$ a cima e a baixo. Este procedimento auxiliou no desenvolvimento da geometria da bobina utilizada nos ensaios.

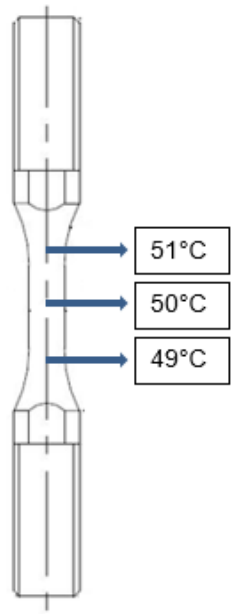

(a)

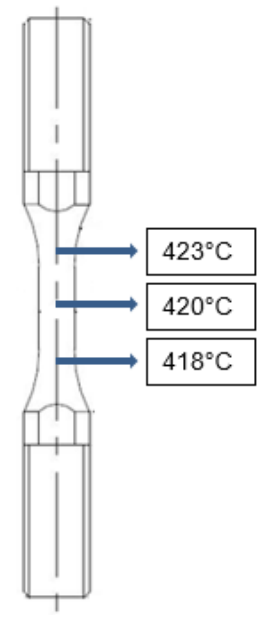

(b)

Figura 21: Leitura dos termopares e variações de temperatura na extensão da área útil do corpo de prova. (a) $50^{\circ} \mathrm{C} \mathrm{e} \mathrm{(b)} 420^{\circ} \mathrm{C}$.

Fonte: Produção do próprio autor. 


\section{RESULTADOS E DISCUSSÃO}

\subsection{Material}

A Tabela 1 apresenta a composição nominal dos ferros fundidos cinzento classe 25 segundo a norma (ASTM A48/A48M-16) [46], e vermicular classe 45 (ASTM A842-11) [52].

Tabela 1: Composição química nominal dos ferros fundidos cinzento e vermicular

Classe

Composição química

\begin{tabular}{cccccc}
\cline { 2 - 6 } ASTM & $\mathrm{C}$ & $\mathrm{Si}$ & $\mathrm{Mn}$ & $\mathrm{P}$ & $\mathrm{S}$ \\
$\mathbf{2 5}$ & $2,5-4,0 \%$ & $1,0-3,0 \%$ & $0,2-1,0 \%$ & $0,002-1,0 \%$ & $0,02-0,25 \%$ \\
$\mathbf{4 5}$ & $2,5-4,0 \%$ & $1,0-3,0 \%$ & $0,2-1,0 \%$ & $0,01-0,1 \%$ & $0,01-0,03 \%$ \\
\hline
\end{tabular}

Fonte: ASTM A48/A48M-16 e ASTM A842-11

A Figura 22 mostra a microestrutura do FFC na condição como recebida, sendo esta constituída por uma matriz $100 \%$ perlítica e veios de grafita com classificação segundo a norma ASTM A247-10 [51] como grafita de forma I do tipo A e tamanho 5-6-4.

No caso do FFV, Figura 23, observa-se que sua matriz é constituída de $93 \%$ de perlita e 7\% ferrita, sendo a grafita classificada conforme a norma SAE 1887/2002 [50], como do tipo III-VI e contendo $11 \%$ de nodularidade, sendo a porcentagem de nodularidade permitida até $20 \%$.
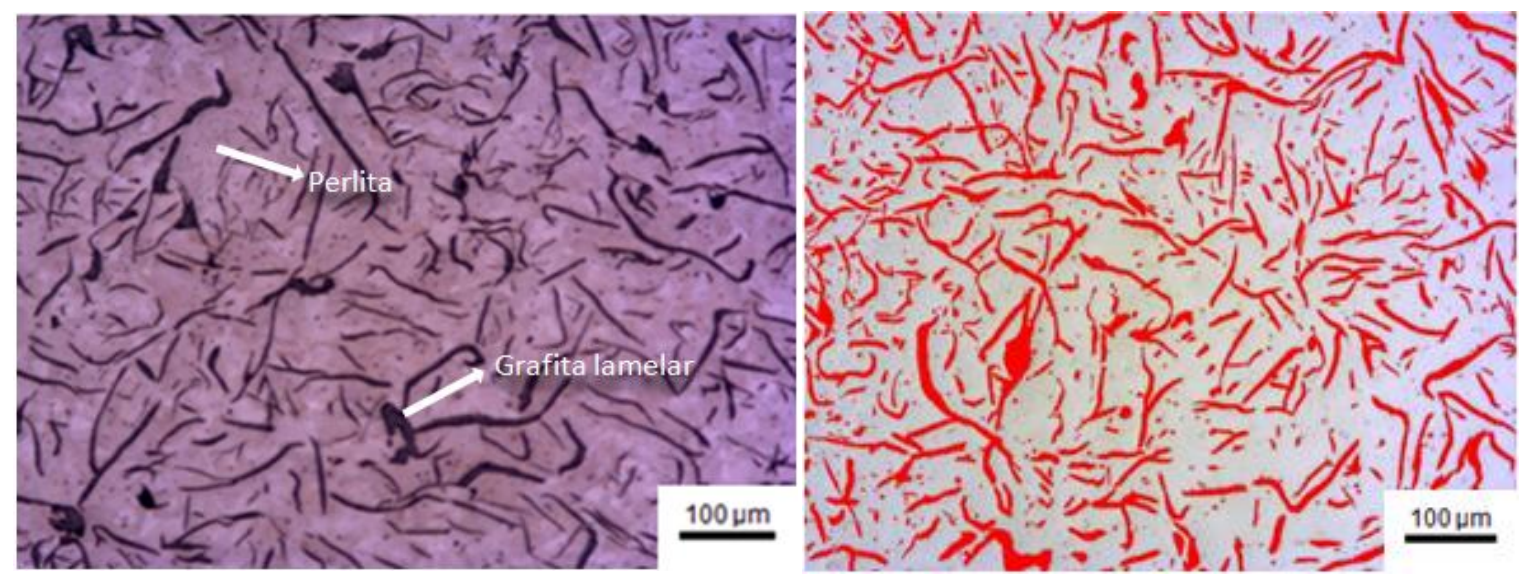

Figura 22: Micrografia evidenciando a distribuição das grafitas no FFC, (a) matriz perlitica com ataque $3 \%$ nital, (b) Análise quantitativa dos veios (média 10\%).

Fonte: Produção do próprio autor. 

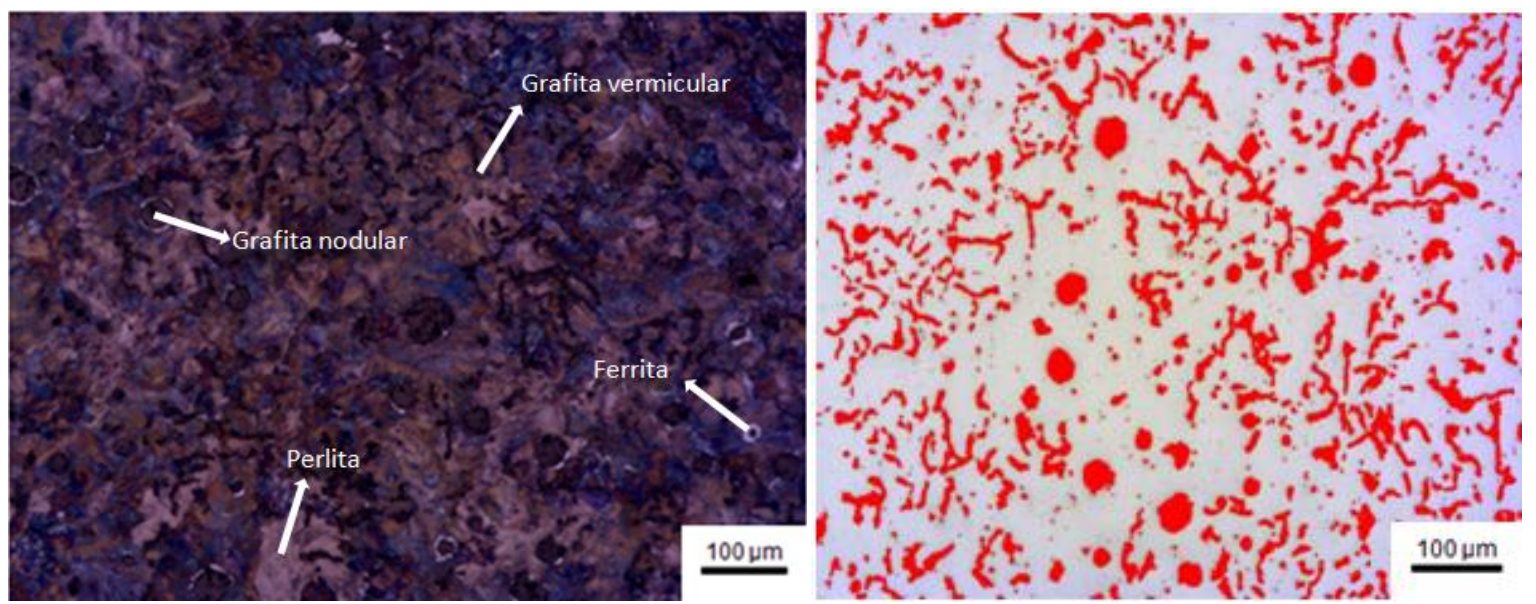

Figura 23: Micrografia evidenciando a distribuição das grafitas do FFV, (a) matriz composta por perlita (média 93\%) e ferrita (7\%) com ataque 3\% nital, (b) Análise quantitativa da grafita (média de 11\%).

Fonte: Produção do próprio autor.

Os resultados da análise quantitativa da microestrutura para avaliação da quantidade de grafita (corte na área em 2D), realizada com um aumento de 100x [51] e em cinco imagens para cada um dos ferros fundidos estudados, são apresentados nas Tabelas 2 e 3.

Tabela 2: Resultados das análises quantitativas de grafita para o FFC

\begin{tabular}{cc}
\hline FFC & \% de Grafita \\
\hline Imagem A & 11 \\
Imagem B & 9 \\
Imagem C & 10 \\
Imagem D & 11 \\
Imagem E & 10 \\
Média & 10 \\
\hline
\end{tabular}

Fonte: Produção do próprio autor.

Tabela 3: Resultados das análises quantitativas de grafita para o FFV

\begin{tabular}{cc}
\hline FFV & \% de Grafita \\
\hline Imagem A & 11 \\
Imagem B & 12 \\
Imagem C & 10 \\
Imagem D & 11 \\
Imagem E & 11 \\
Média & 11 \\
\hline
\end{tabular}

Fonte: Produção do próprio autor. 


\subsection{Ensaio de tração}

As Figuras 24 e 25 apresentam as curvas de tensão versus deformação dos dois materiais em estudo, obtidas nos ensaios de tração. O módulo elástico foi obtido pelo modulo secante. Estes resultados são sumarizados nas Tabelas de 4 a 7, sendo que as Tabelas 8 e 9 apresentam os valores de redução das propriedades mecânica em função da elevação da temperatura. Assim, observa-se que o FFC apresenta valores médios do módulo elástico, E $=117$ e $108 \mathrm{GPa}$ (redução de 9\%), da tensão de ruptura, $\sigma_{R}=258$ e $230 \mathrm{MPa}$ (redução de $12 \%$ ), da tensão de escoamento, $\sigma_{\mathrm{e}}=224$ e $189 \mathrm{MPa}$ (redução de 16\%) e alongamento total, $\mathrm{Al}=1 \%$, respectivamente para as temperaturas de 50 e $420^{\circ} \mathrm{C}$. O FFV apresenta valores médios do módulo elástico, $\mathrm{E}=152$ e $134 \mathrm{GPa}$ (redução de 9\%), da tensão de ruptura, $\sigma_{\mathrm{R}}=$ 522 e $430 \mathrm{MPa}$ (redução de 20\%), da tensão de escoamento, $\sigma_{\mathrm{e}}=409$ e $340 \mathrm{MPa}$ (redução de $18 \%$ ) e alongamento total, $\mathrm{Al}=2 \%$, respectivamente para as temperaturas de 50 e $420^{\circ} \mathrm{C}$. Assim, estando estes valores em conformidade com a Norma ASTM A48/A48M/03 [46] e trabalhos de Gilbert [53].

Normalmente, com o aumento da temperatura, os metais tendem a apresentar uma diminuição nos parâmetros de resistência mecânica e aumento da ductilidade, pois com o aumento da temperatura a mobilidade atômica é aumentada e a deformação plástica favorecida. Entretanto, a variação de temperatura não foi suficiente para causar um aumento significativo no alongamento total que permaneceu em $1 \%$ no caso do FFC e $2 \%$ no caso do FFV. 


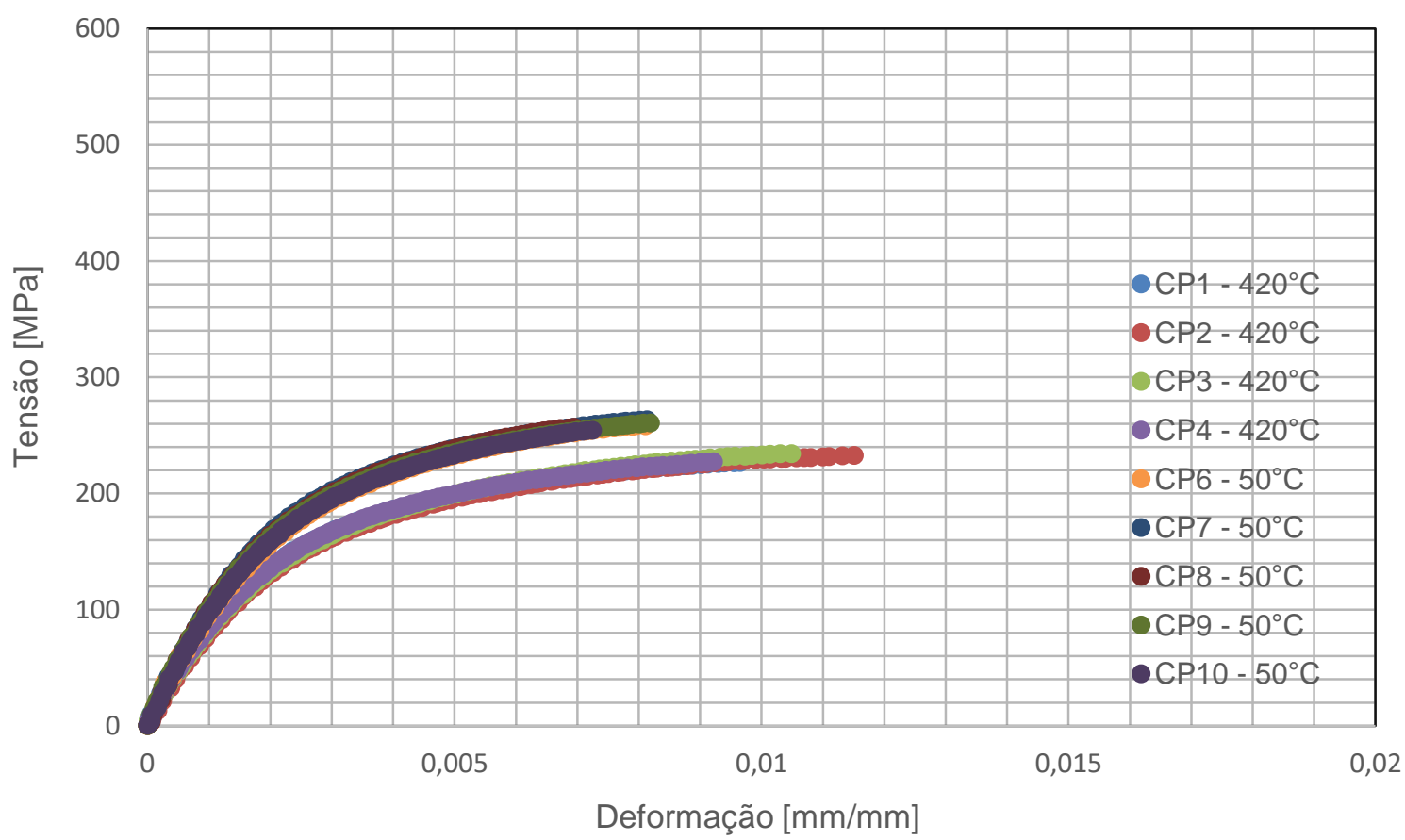

Figura 24: Gráfico tensão x deformação dos ensaios de tração nas temperaturas 50 e $420^{\circ} \mathrm{C}$ para o FFC.

Fonte: Produção do próprio autor.

Tabela 4: Resultados dos ensaios de tração do material FFC na temperatura $50{ }^{\circ} \mathrm{C}$

\begin{tabular}{cccccc}
\hline $\begin{array}{c}\text { FFC - } \\
\text { Temperatura } \\
\mathbf{5 0} \mathbf{~}^{\circ} \mathbf{C}\end{array}$ & $\begin{array}{c}\text { Tensão } \\
\text { Máxima } \\
\text { (MPa) }\end{array}$ & $\begin{array}{c}\text { Limite de } \\
\text { Escoamento } \\
\text { (MPa) }\end{array}$ & $\begin{array}{c}\text { E } \\
\text { (GPa) }\end{array}$ & $\begin{array}{c}\text { Limite de } \\
\text { Ruptura } \\
\text { (MPa) }\end{array}$ & $\begin{array}{c}\text { Alongamento } \\
\text { (\%) }\end{array}$ \\
\hline CP - - & 258 & 222 & 117 & 258 & 0,8 \\
CP - 7 & 263 & 226 & 119 & 263 & 0,8 \\
CP - 8 & 257 & 223 & 119 & 257 & 0,7 \\
CP - 9 & 260 & 228 & 117 & 260 & 0,8 \\
CP - 10 & 254 & 222 & 115 & 254 & 1 \\
Média & 258 & 224 & 117 & 258 & 1 \\
Desvio Padrão & 3 & 2 & 1 & 3 & 0 \\
\hline
\end{tabular}

Fonte: Produção do próprio autor.

Tabela 5: Resultados dos ensaios de tração do material FFC na temperatura de $420^{\circ} \mathrm{C}$

\begin{tabular}{cccccc}
\hline $\begin{array}{c}\text { FFC - } \\
\text { Temperatura } \\
\mathbf{4 2 0} \mathbf{~}^{\circ} \mathbf{C}\end{array}$ & $\begin{array}{c}\text { Tensão Máxima } \\
\text { (MPa) }\end{array}$ & $\begin{array}{c}\text { Limite de } \\
\text { Escoamento } \\
\text { (MPa) }\end{array}$ & $\begin{array}{c}\text { E } \\
\text { (GPa) }\end{array}$ & $\begin{array}{c}\text { Limite de } \\
\text { Ruptura } \\
\text { (MPa) }\end{array}$ & $\begin{array}{c}\text { Alongamento } \\
\text { (\%) }\end{array}$ \\
\hline CP - 1 & 227 & 189 & 106 & 226 & 1 \\
CP - 2 & 233 & 188 & 105 & 232 & 1,1 \\
CP - 3 & 234 & 189 & 112 & 233 & 1 \\
CP - 4 & 227 & 187 & 107 & 227 & 1 \\
Média & 230 & 188 & 108 & 230 & 1 \\
Desvio Padrão & 4 & 0 & 3 & 4 & 0 \\
\hline
\end{tabular}

Fonte: Produção do próprio autor. 


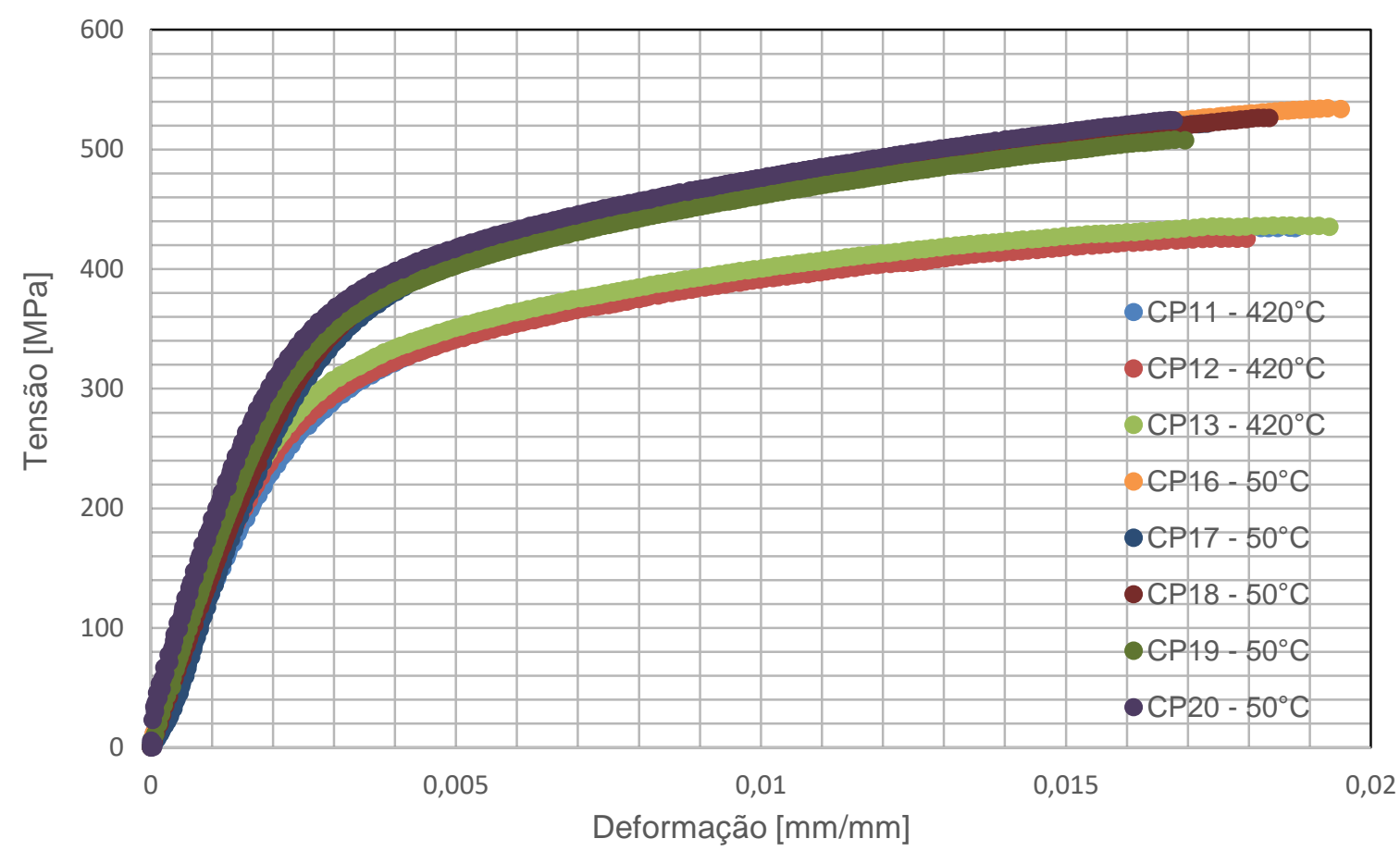

Figura 25: Gráfico tensão x deformação dos ensaios de tração nas temperaturas 50 e $420^{\circ} \mathrm{C}$ para o FFV.

Fonte: Produção do próprio autor.

Tabela 6: Resultados dos ensaios de tração do material FFV na temperatura de $50{ }^{\circ} \mathrm{C}$

\begin{tabular}{cccccc}
\hline $\begin{array}{c}\text { FFV - } \\
\text { Temperatura } \\
\mathbf{5 0} \mathbf{~}^{-} \mathbf{C}\end{array}$ & $\begin{array}{c}\text { Tensão } \\
\text { Máxima } \\
\text { (MPa) }\end{array}$ & $\begin{array}{c}\text { Limite de } \\
\text { Escoamento } \\
\text { (MPa) }\end{array}$ & $\begin{array}{c}\text { E } \\
\text { (GPa) }\end{array}$ & $\begin{array}{c}\text { Limite de } \\
\text { Ruptura (MPa) }\end{array}$ & $\begin{array}{c}\text { Alongamento } \\
\text { (\%) }\end{array}$ \\
\hline CP - 16 & 534 & 408 & 158 & 533 & 1,9 \\
CP - 17 & 522 & 412 & 150 & 521 & 1,7 \\
CP - 18 & 526 & 411 & 146 & 526 & 1,8 \\
CP - 19 & 508 & 403 & 153 & 508 & 1,7 \\
CP - 20 & 524 & 410 & 154 & 524 & 1,7 \\
Média & 523 & 409 & 152 & 522 & 2 \\
Desvio Padrão & 9 & 4 & 4 & 9 & 0 \\
\hline
\end{tabular}

Fonte: Produção do próprio autor.

Tabela 7: Resultados dos ensaios de tração do material FFV na temperatura de $420^{\circ} \mathrm{C}$

\begin{tabular}{cccccc}
\hline $\begin{array}{c}\text { FFV - } \\
\text { Temperatura } \\
\mathbf{4 2 0} \mathbf{~} \mathbf{C}^{\text {C }}\end{array}$ & $\begin{array}{c}\text { Tensão } \\
\text { Máxima } \\
\text { (MPa) }\end{array}$ & $\begin{array}{c}\text { Limite de } \\
\text { Escoamento } \\
\text { (MPa) }\end{array}$ & $\begin{array}{c}\text { E } \\
\text { (GPa) }\end{array}$ & $\begin{array}{c}\text { Limite de } \\
\text { Ruptura } \\
\text { (MPa) }\end{array}$ & $\begin{array}{c}\text { Alongamento } \\
\text { (\%) }\end{array}$ \\
\hline CP - 11 & 434 & 338 & 129 & 434 & 1,9 \\
CP - 12 & 425 & 341 & 136 & 423 & 1,9 \\
CP - 13 & 436 & 343 & 138 & 435 & 1,9 \\
Média & 431 & 340 & 134 & 430 & 2 \\
Desvio Padrão & 29 & 11 & 9 & 29 & 0 \\
\hline
\end{tabular}

Fonte: Produção do próprio autor. 
Tabela 8: Redução das propriedades mecânicas devido ao aquecimento em $420{ }^{\circ} \mathrm{C}$ no material FFC.

\begin{tabular}{cc}
\hline FFC & Redução da Propriedade Mecânica (\%) \\
\hline Tensão Máxima & 12 \\
Limite de Escoamento & 16 \\
E (GPa) & 9 \\
\hline
\end{tabular}

Fonte: Produção do próprio autor.

Tabela 9: Redução das propriedades mecânicas devido ao aquecimento em $420^{\circ} \mathrm{C}$ no material FFV

\begin{tabular}{cc}
\hline FFV & Redução da Propriedade Mecânica (\%) \\
\hline Tensão Máxima & 20 \\
Limite de Escoamento & 18 \\
E (GPa) & 9 \\
\hline
\end{tabular}

Fonte: Produção do próprio autor.

Após análise do trabalho de GUESSER [20] e GILBERT [53], observa-se que a variação do módulo elástico é linear com a temperatura, ver Figura 26, assim a partir de dois pontos $\left(50\right.$ e $\left.420{ }^{\circ} \mathrm{C}\right)$ foi obtida a equação de $\mathrm{E}(\mathrm{T})$, que será utilizada posteriormente para o cálculo do valor da deformação elástica no ensaio de fadiga termomecânica.

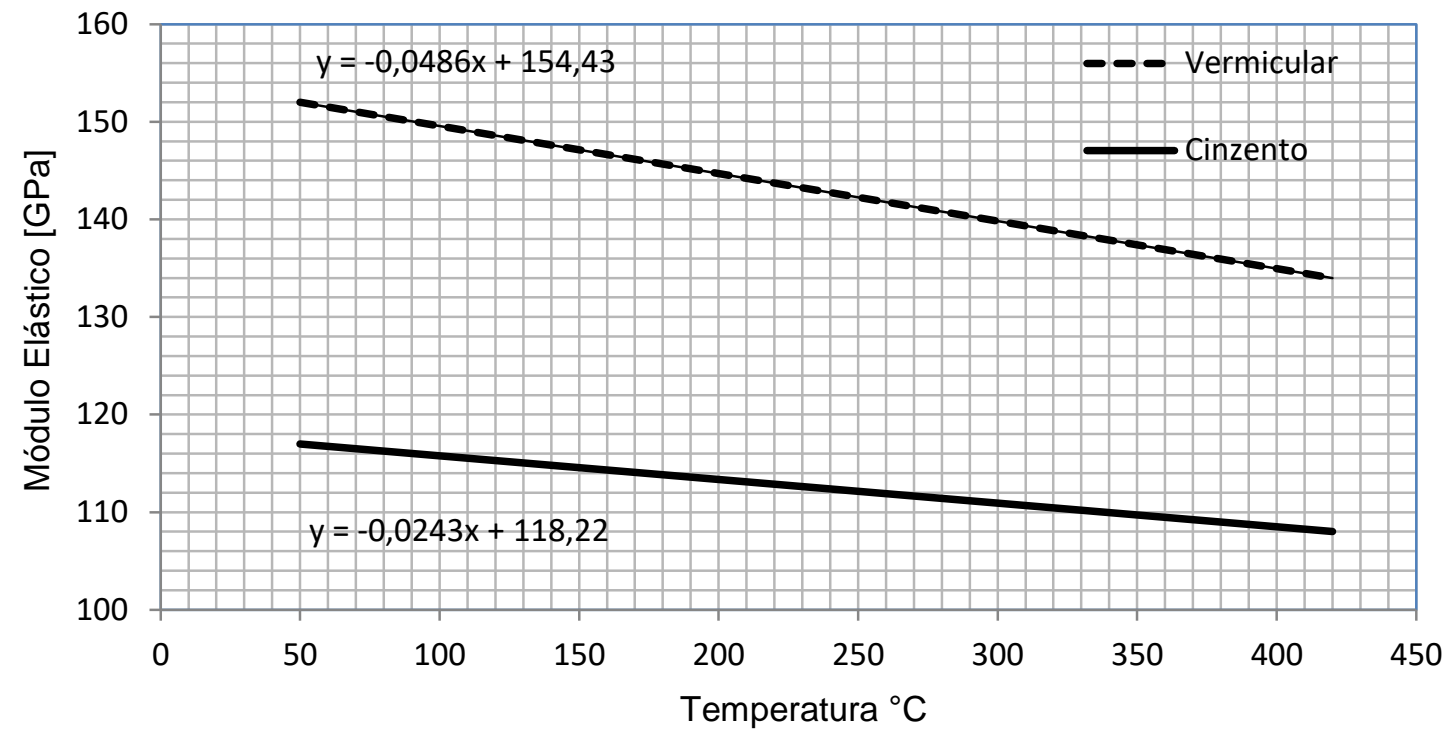

Figura 26: Variação do módulo de elasticidade com a temperatura de ensaios para os materiais FFV e FFC.

Fonte: Produção do próprio autor. 
Ainda, sabe-se que o efeito da quantidade e morfologia da grafita afeta fortemente o módulo de elasticidade. Observa-se que ambos possuem a mesma quantidade de grafita, mas o FFV apresenta E maior dada à morfologia dos veios de grafita [20].

\subsection{Ensaio de fadiga termomecânica}

O ensaio de FTM sob-restrição total é equivalente a induzir ciclicamente um valor fixo de deformação mecânica, esta quantidade é de igual valor, mas de sinal oposto ao da deformação térmica. No intervalo de temperatura de 50 a $420{ }^{\circ} \mathrm{C}$ esta corresponde a aproximadamente 0,577\%, conforme equação 4 e Figura 27, considerando um valor médio do coeficiente de dilatação, $\alpha=15,6 \times 10^{-6}$. Observa-se que o tempo total do ciclo é de $300 \mathrm{~s}$.

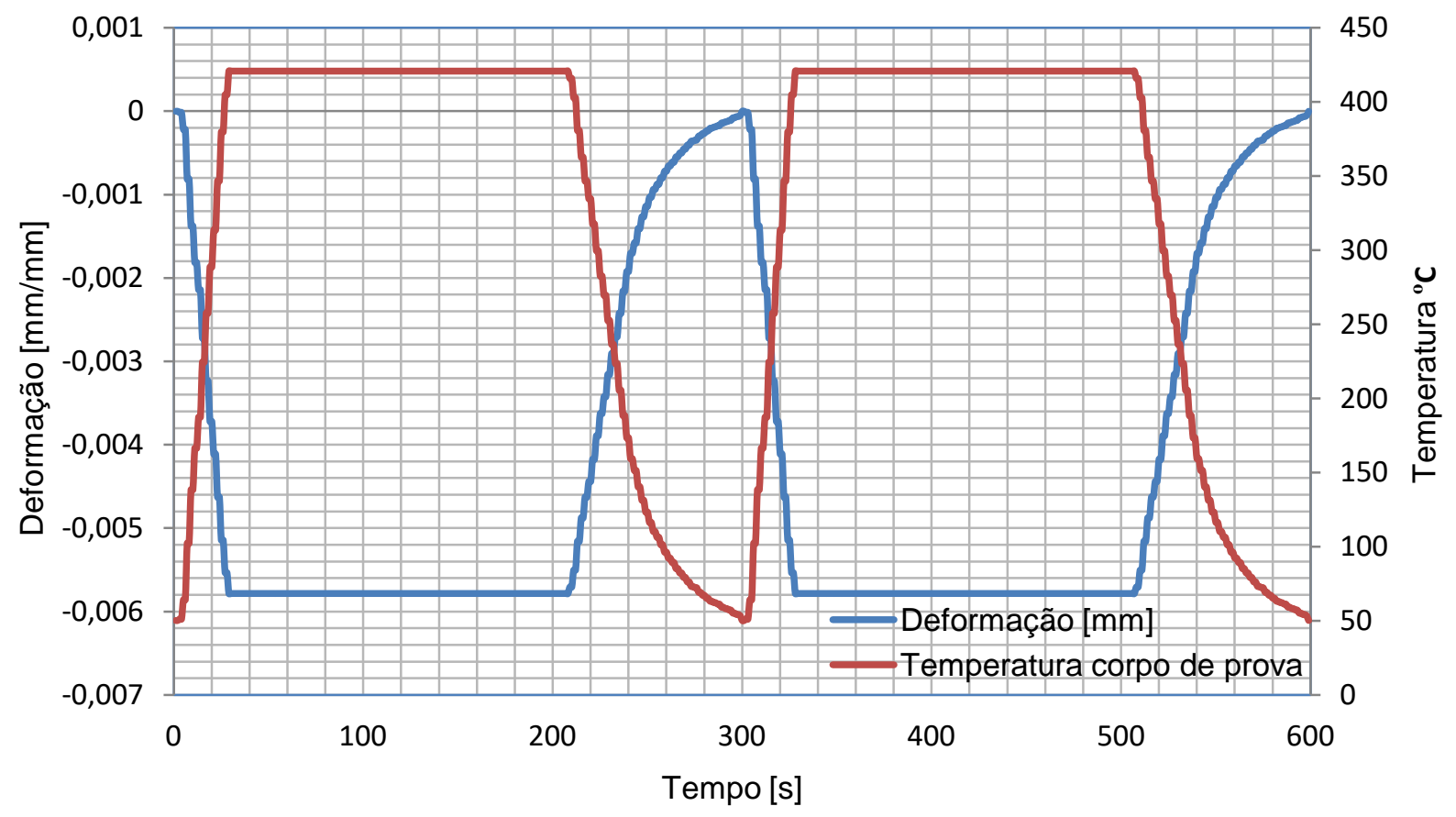

Figura 27: Deformação térmica total de aproximadamente $0,577 \%$ para o intervalo de temperatura de $50-420^{\circ} \mathrm{C}$.

Fonte: Produção do próprio autor.

A Figura 28 ilustra o comportamento da histerese tensão-deformação para o ciclo térmico em controle de deformação e com deformação total igual a zero. Independentemente do tipo de ferro fundido, o primeiro ciclo é diferente dos demais pela ocorrência de intensa deformação plástica gerada na primeira dilatação do corpo de prova. Alguns pontos mais distintos do ensaio podem ser identificados na histerese do primeiro ciclo, sendo estes representados pelas letras de A até J. Assim, como resultado do primeiro aquecimento a partir de $50{ }^{\circ} \mathrm{C}(\mathrm{A})$, uma tensão compressiva é desenvolvida, sendo o início da deformação plástica 
(ponto B) em aproximadamente -220 MPa para FFC e -280 MPa (correspondendo ao desvio da linearidade). Continuando o aquecimento, observa-se um aumento tanto da tensão quanto da deformação devido ao encruamento dos materiais, sendo atingida uma tensão máxima compressiva (ponto C) -290 MPa para FFC e -310 MPa em aproximadamente $335{ }^{\circ} \mathrm{C}$ para FFV e $358^{\circ} \mathrm{C}$ para o FFV. Após o atendimento da máxima tensão observa-se a ocorrência de relaxação de tensão (entre os pontos C-D-E) para aproximadamente -220 MPa para FFC e $210 \mathrm{MPa}$ FFV quando o patamar em $420{ }^{\circ} \mathrm{C}$ é concluído, ver Figura 29. Com o início do resfriamento (ponto F), em aproximadamente $276^{\circ} \mathrm{C}$ para $\mathrm{FFC}$ e $305^{\circ} \mathrm{C}$ para o $\mathrm{FFV}$, sendo a tensão nula, dando início a fase trativa do ciclo, com o final do carregamento elástico linear no ponto (G) em uma tensão de $80 \mathrm{MPa}$ para FFC e $110 \mathrm{MPa}$ para o FFV, em seguida com o aumento do encruamento, na temperatura de $50{ }^{\circ} \mathrm{C}$ é atingida a máxima tensão trativa (ponto H), sendo esta 147 MPa para FFC e 220 MPa para o FFV, não sendo observada a ocorrência de relaxação de tensão.

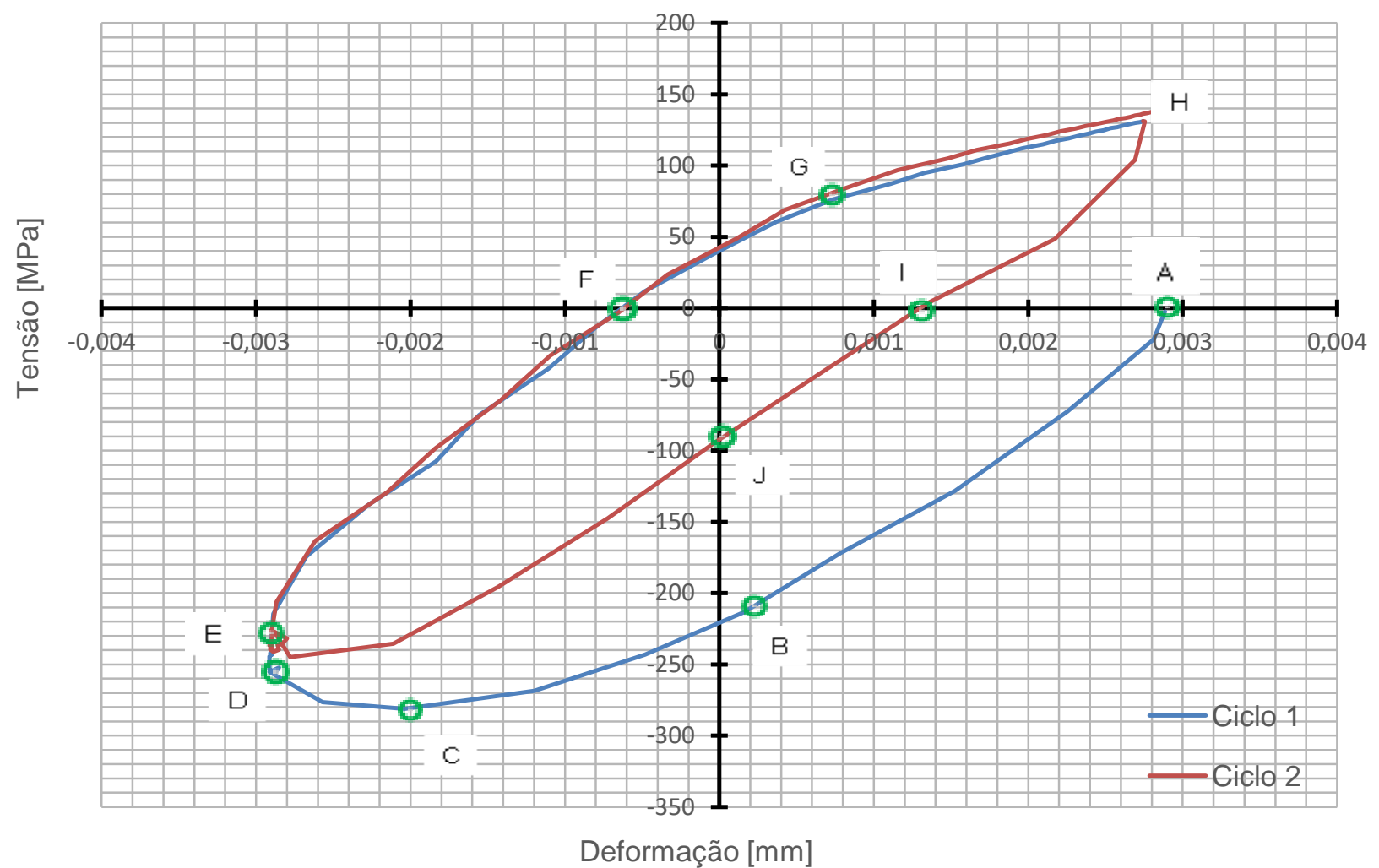

(a) 


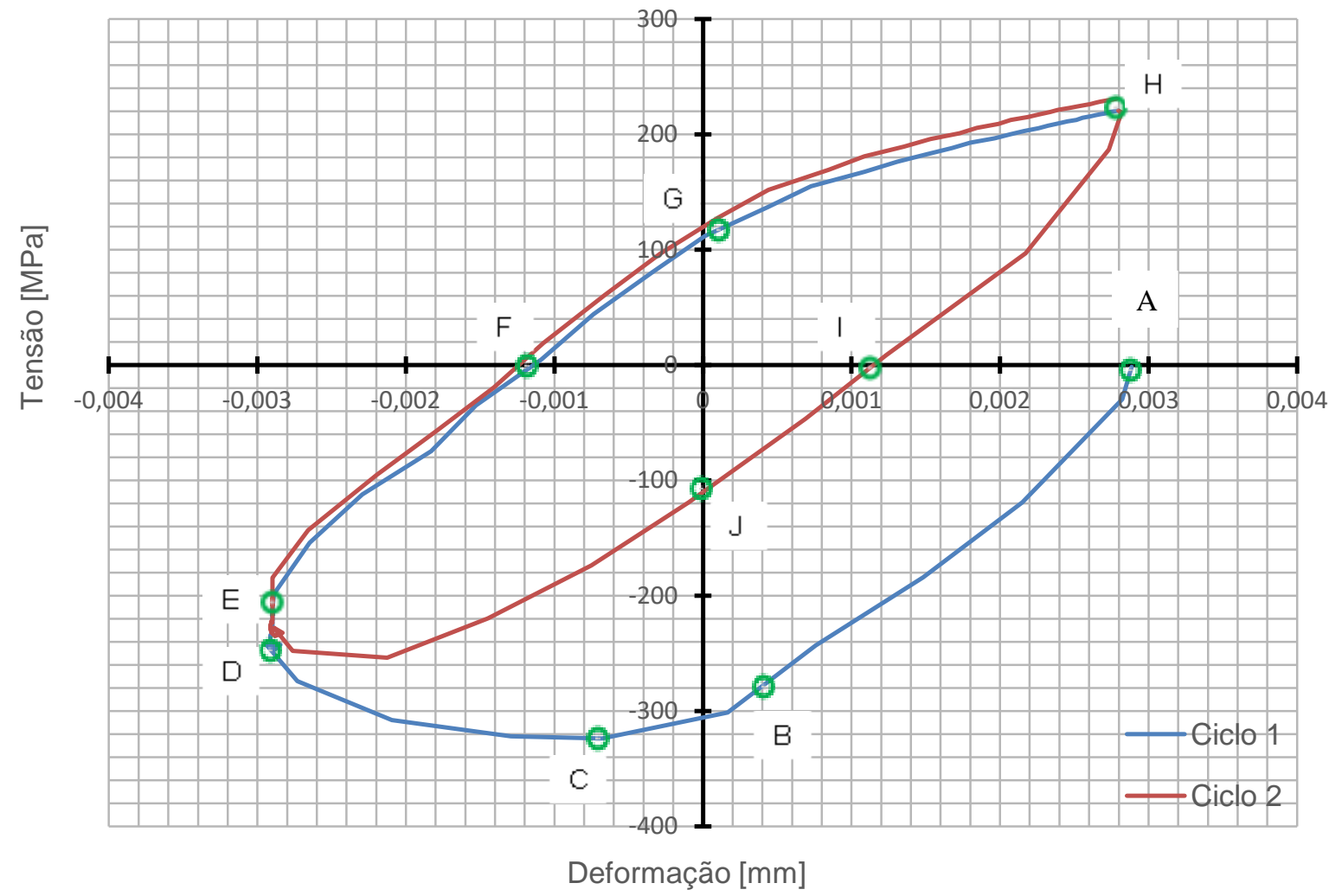

(b)

Figura 28: (a) FFC-CP2 108 ciclos (b) FFV-CP 610 ciclos. Análise do primeiro e segundo ciclo térmico por FTM. São detalhados o inicio de escoamento (B), atendimento de carga máxima em compressão (C), inicio (D) e final (E) do patamar de temperatura, inicio do carregamento trativo (F) e inicio da deformação plástica $(\mathrm{G})$, com atendimento da máxima tensão trativa $(\mathrm{H})$. No segundo ciclo a tensão vai a zero em (I) e o escoamento é iniciado em (J).

Fonte: Produção do próprio autor. 


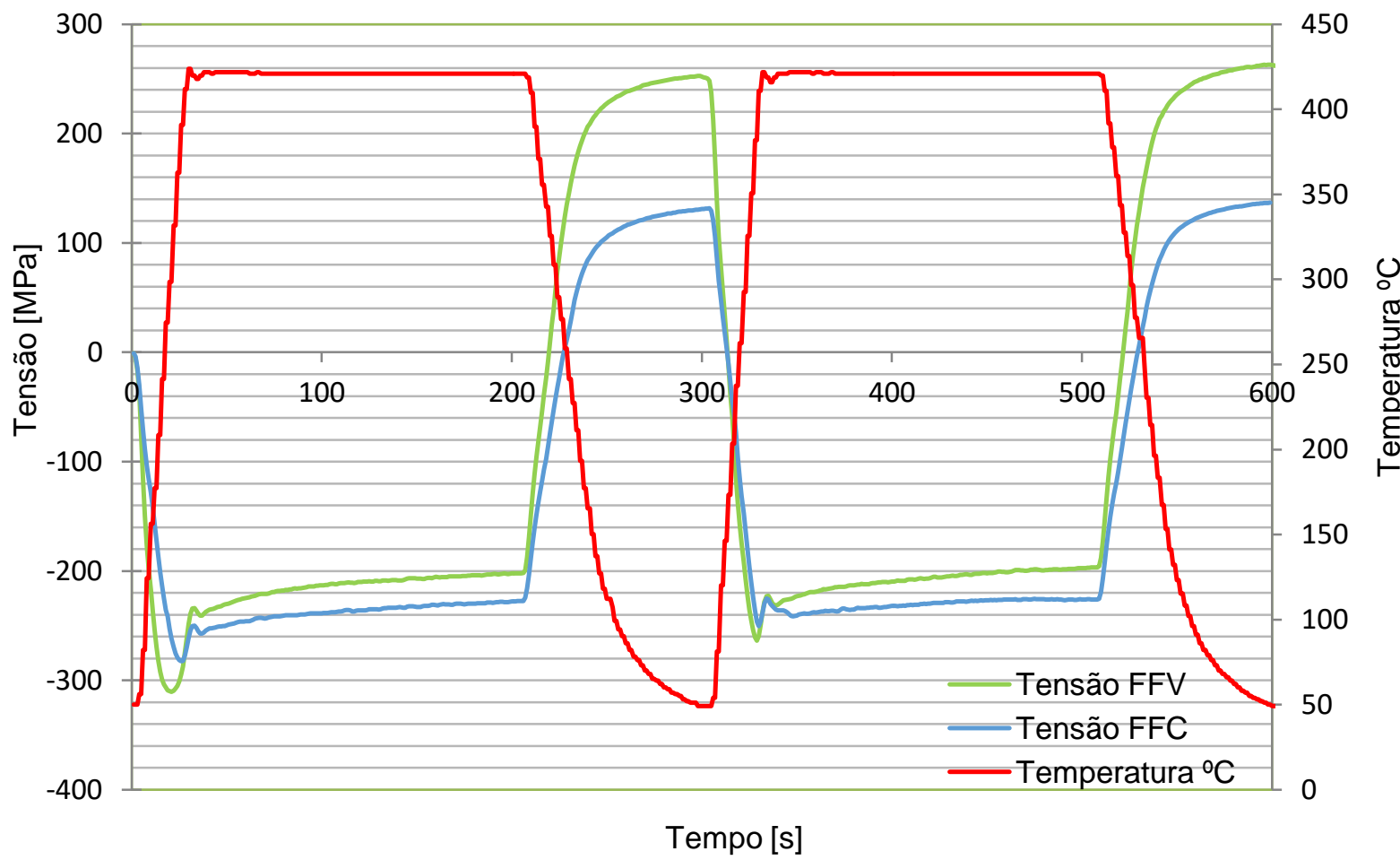

Figura 29: Análise da tensão nos dois primeiros ciclos térmicos em FTM. Observa-se a relaxação de tensão em ambos os tipos de ferro fundido.

Fonte: Produção do próprio autor.

No início do segundo ciclo térmico, à medida que a temperatura aumenta a tensão trativa é reduzida, sendo que, na temperatura de $145^{\circ} \mathrm{C}$, para ambos os ferros fundidos à tensão está próxima de zero (ponto I). O ponto (J) indica o início da deformação plástica, sendo -80 MPa para FFC e -100 MPa para o FFV. A razão para esta mudança é devido à deformação plástica e ao encruamento ocorridos na evolução do primeiro ciclo. Estas tensões vão sendo alteradas à medida que os ciclos térmicos vão sendo aplicados, ver Figura 30. Pode ser observado que à medida que ambos os materiais vão sendo deformados ciclicamente, ocorre um aumento da tensão trativa indicando que a resistência do material está aumentando devido ao endurecimento cíclico (deformação total zero e a deformação térmica constante). Estas observações estão de acordo com o trabalho de GHODRAT 2013, [7].

Assim, com a evolução dos ciclos, a tensão média fica gradativamente positiva, sendo o módulo da tensão mínima reduzido (esta acontece na máxima temperatura) e na parte trativa do ciclo, a tensão máxima é aumentada (acontece na menor temperatura). Ao mesmo tempo a quantidade de relaxação de tensão a $420^{\circ} \mathrm{C}$ diminui gradualmente e a forma da histerese tende a tornar-se mais estreita, indicando uma redução na deformação plástica cíclica, GHODRAT 2013 , [7]. Esta redução na plasticidade cíclica para o FFC variou de $\Delta \varepsilon_{\text {p2ciclos }}=0,5 \%$ para o 
segundo ciclo para $\Delta \varepsilon_{\mathrm{p}>100 \text { ciclos }}=0,3 \%$ após mais de 100 ciclos (ver média de ciclos mostrado na Tabela 11), o que fornece uma redução de $40 \%$ na plasticidade. No caso do FFV esta redução foi de $\Delta \varepsilon_{\mathrm{p} 2 \text { ciclos }}=0,5 \%$ para $\Delta \varepsilon_{\mathrm{p}>550 \text { ciclos }}=0,2 \%$, o que fornece uma redução de $60 \%$ na plasticidade. Esta variação foi similar a encontrada por GHODRAT 2013, [7], que em estudo similar, mas em um tempo de patamar de 30s, estudou a vida de um FFV de mesma grade do estudado aqui, observando uma variação na plasticidade cíclica de $\Delta \varepsilon_{\text {p2ciclos }}=0,1 \%$ para $\Delta \varepsilon_{\text {p1000ciclos }} 0,04 \%$, o que fornece uma redução de $60 \%$. Esta variação pode ser observada melhor na Figura 31.

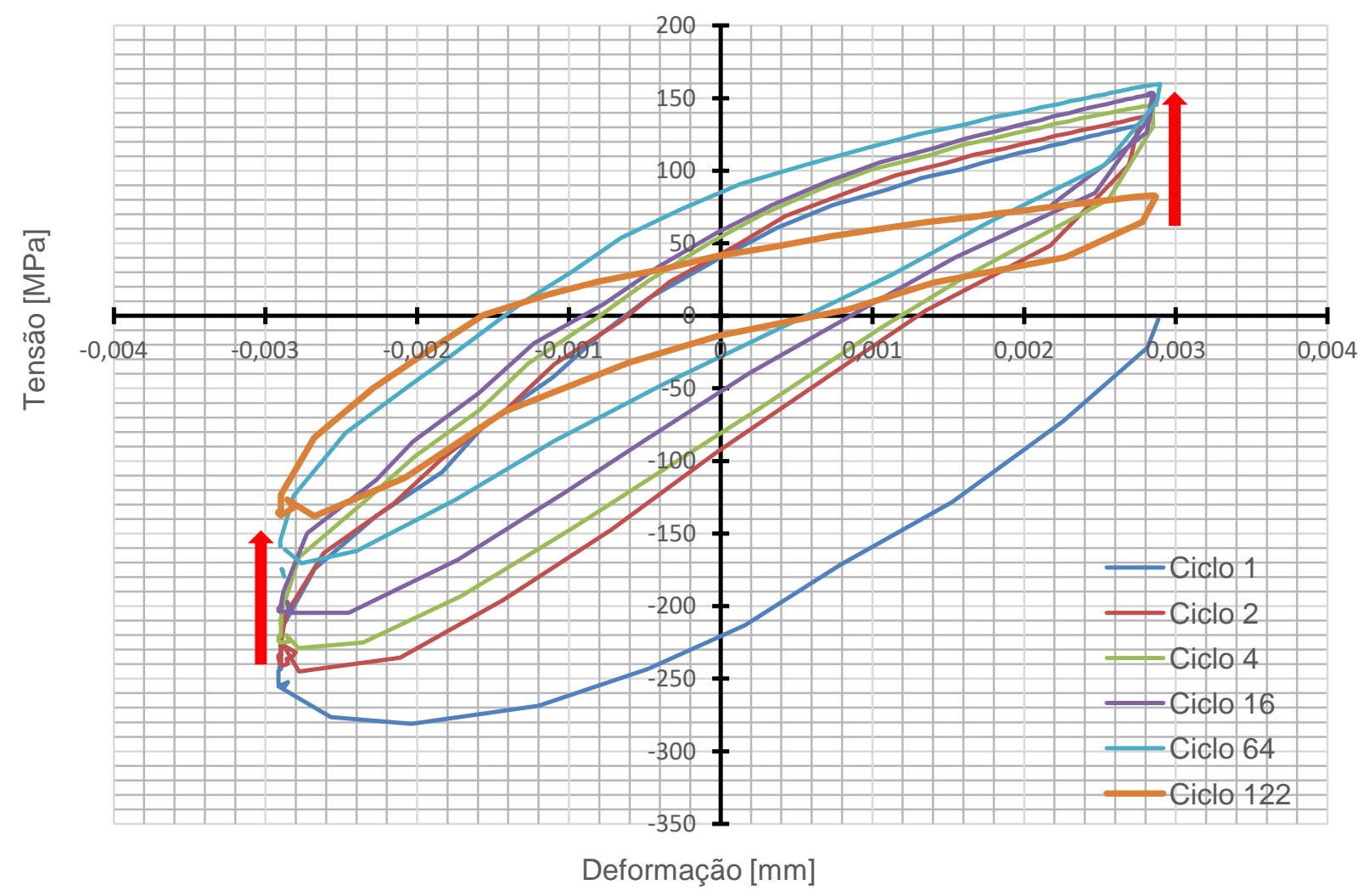

(a) 


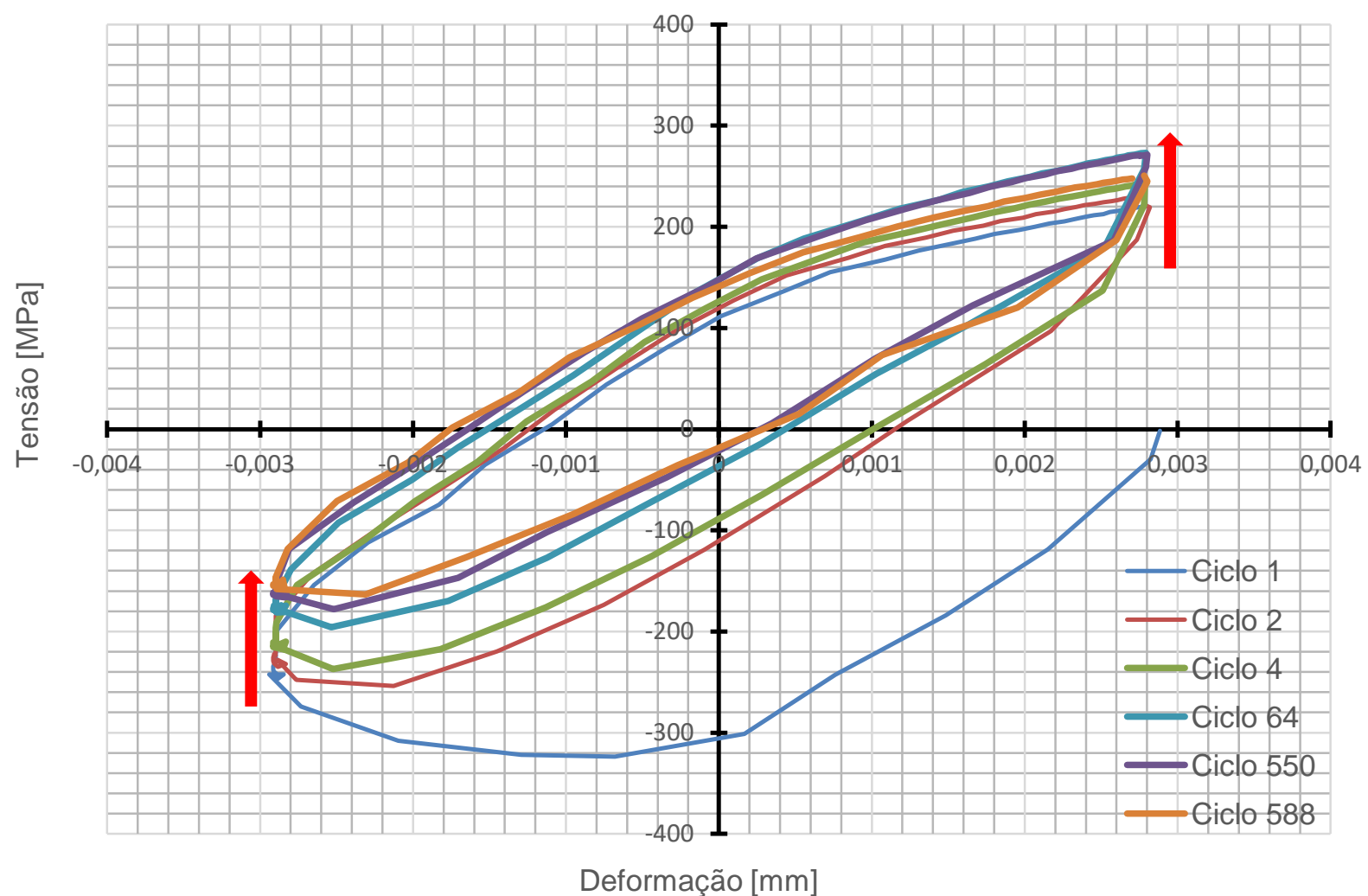

(b)

Figura 30: (a) FFC-CP2 108 ciclos (b) FFV-CP 610 ciclos. Desenvolvimento tensão x deformação durante o ensaio FTM.

Fonte: Produção do próprio autor.

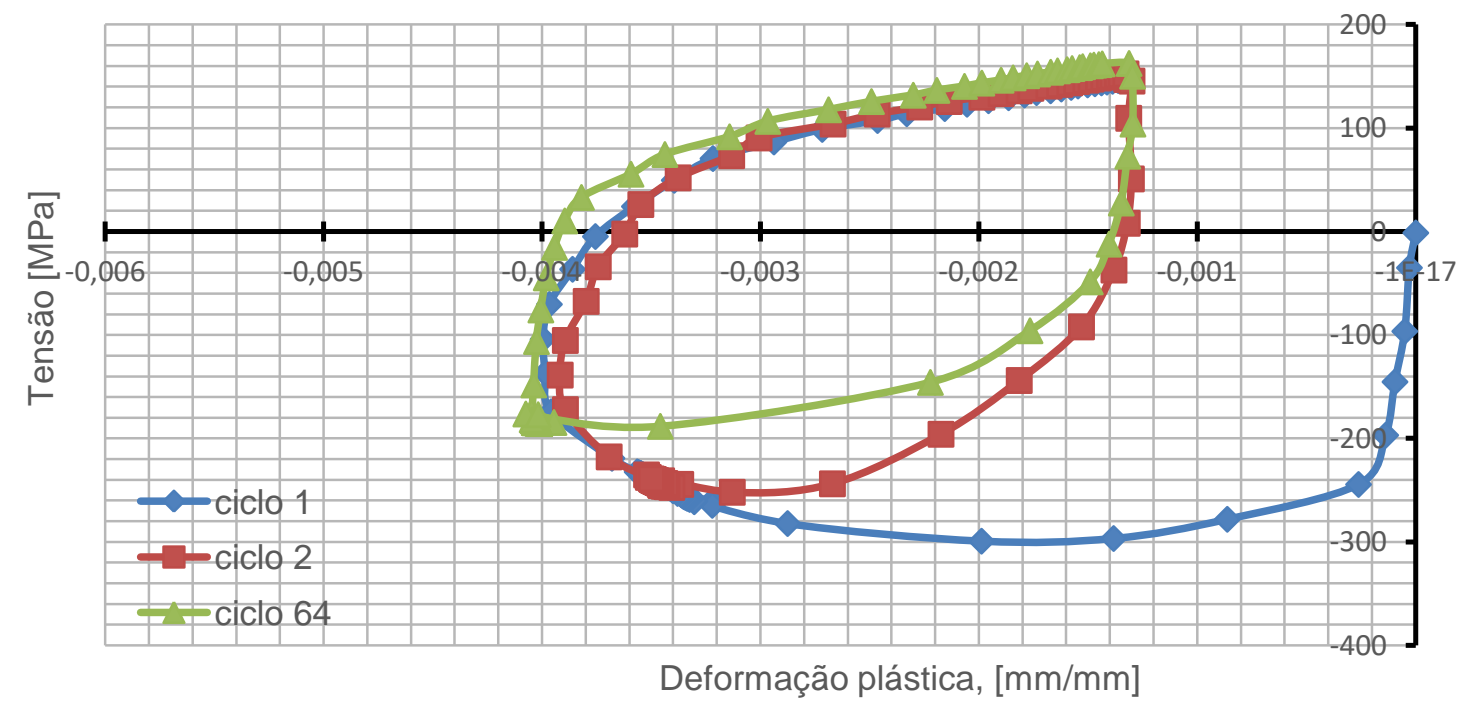

(a) 


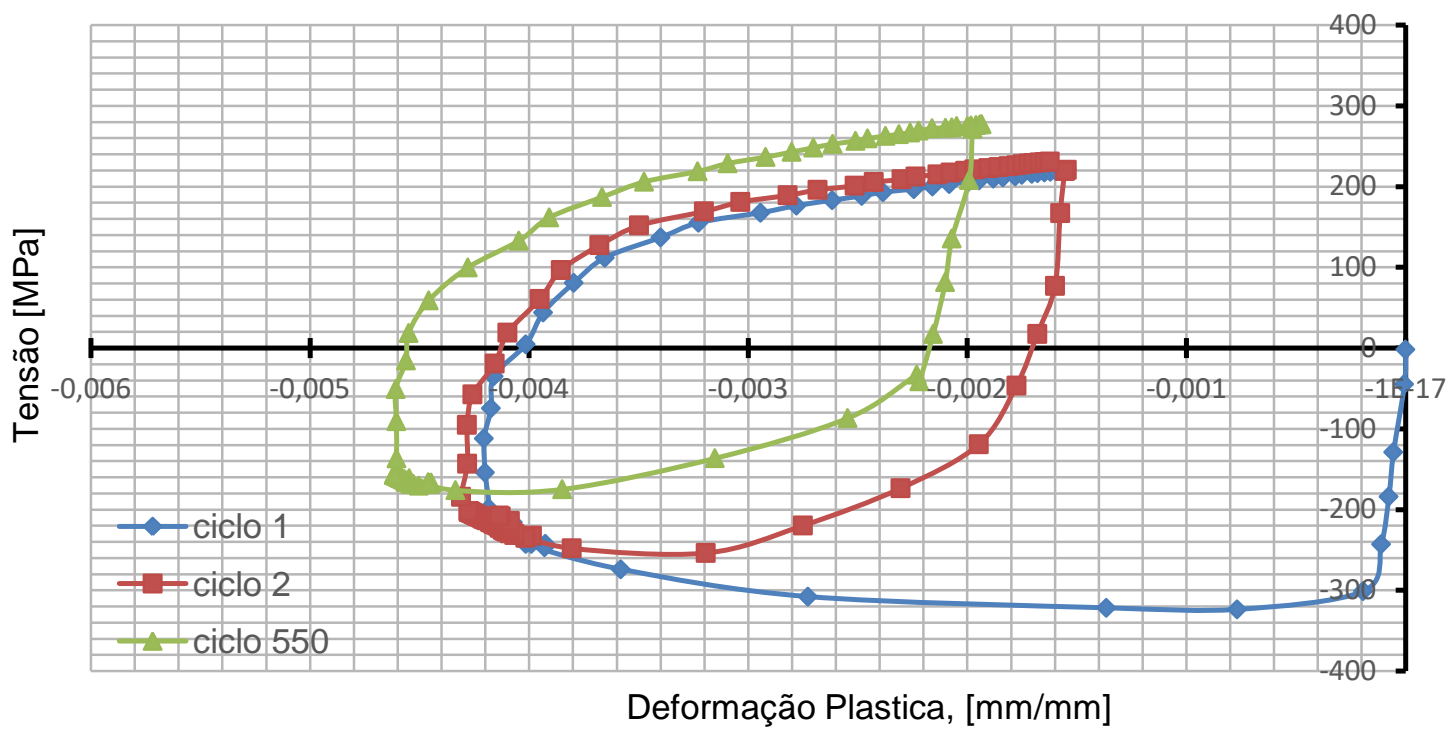

(b)

Figura 31: Evolução da histerese tensão x deformação plástica no ensaio de FTM, (a) FFCCP2, vida de 108 ciclos (b) FFV-CP vida de 610 ciclos.

Fonte: Produção do próprio autor.

Observa-se que tanto para o ferro fundido cinzento quanto o ferro fundido vermicular a maior deformação plástica ocorre no primeiro ciclo, e com o aumento dos ciclos esta diminui gradualmente.

Pode-se observar no ensaio de FTM, nas Figuras 32 até 40, que as tensões compressivas de ambos os materiais são relativamente semelhantes, mas na parte trativa do ciclo eles possuem comportamento bastante diferente. Como é de conhecimento e discutido por LANGMAYR 2004 [55], o FFC apresenta-se menos resistente a tensões trativas devido a sua sensibilidade a formação de defeitos e assim, o desvio da linearidade acontece logo no início da parte trativa do ciclo e o atendimento da deformação total $(0,577 \%)$ acontece a uma menor tensão, cerca de 39,7 \% menor que a do FFV, ver Tabela 10. Entretanto, observa-se que a deformação plástica no $2^{\circ}$ ciclo é a mesma para os dois tipos de ferros fundidos, mas o FFC apresenta vida muito inferior ao FFV, ver Tabela 11, mostrando que para uma mesma amplitude de deformação plástica o dano no FFC é muito maior, sendo isso devido a grande diferença de morfologia das grafitas, pois ambas as matrizes são constituídas primariamente de perlita (Figuras 22 e 23). Para a morfologia em flocos do FFC a evolução das trincas acontece com maior facilidade deixando sua resistência em tração menor comparado com o FFV. 


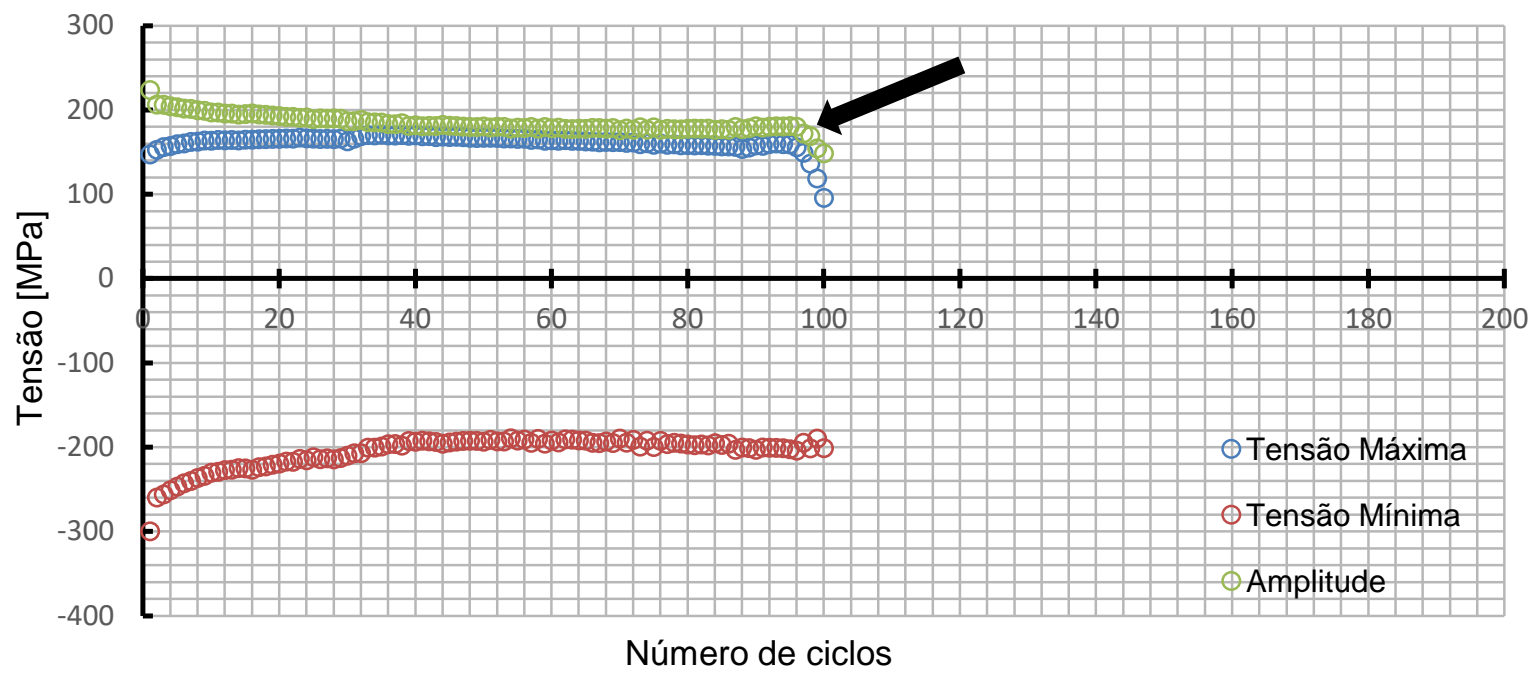

Figura 32: Evolução das tensões durante os ciclos térmicos (FFC-CP1) falha por fratura em 97 Ciclos.

Fonte: Produção do próprio autor.

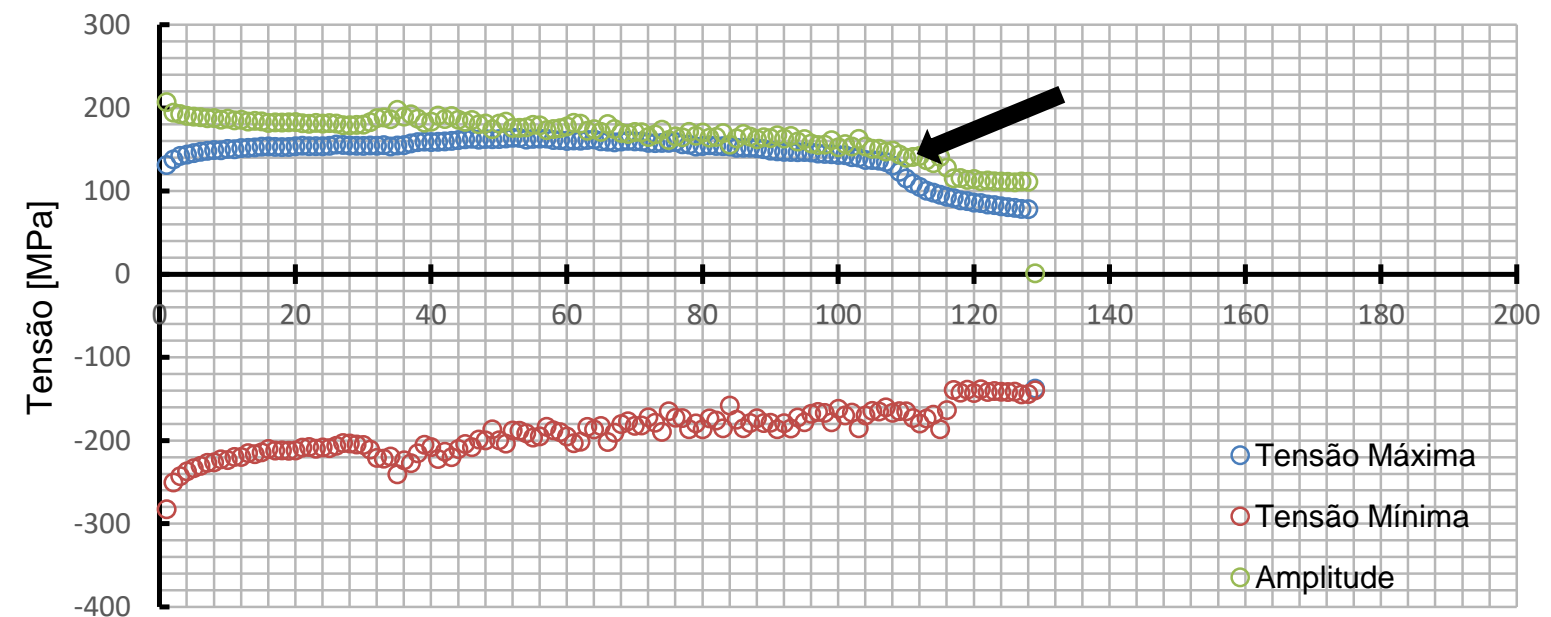

Número de ciclos

Figura 33: Evolução das tensões durante os ciclos térmicos (FFC-CP2) falha por inicio de queda em 108 ciclos.

Fonte: Produção do próprio autor. 


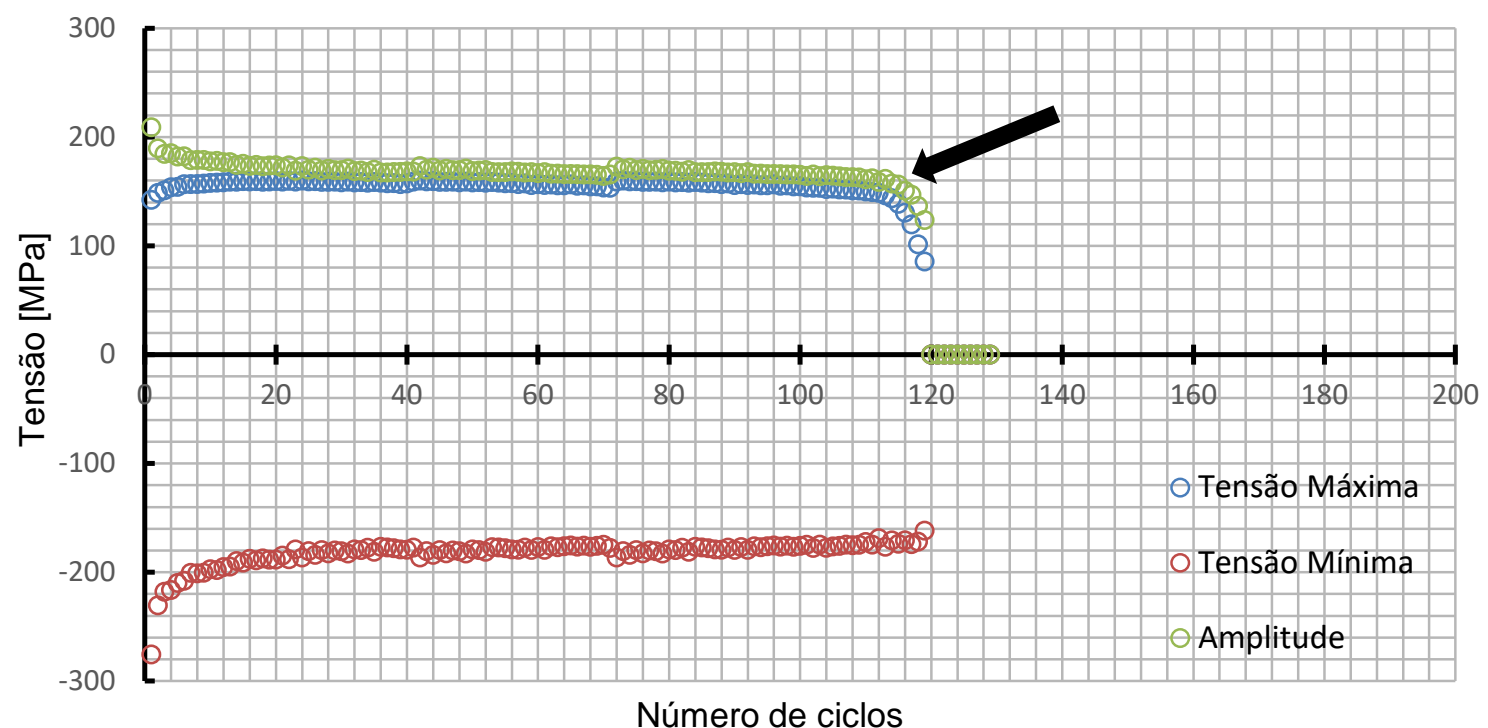

Figura 34: Evolução das tensões durante os ciclos térmicos (FFC-CP3) falha por fratura em 116 ciclos.

Fonte: Produção do próprio autor.

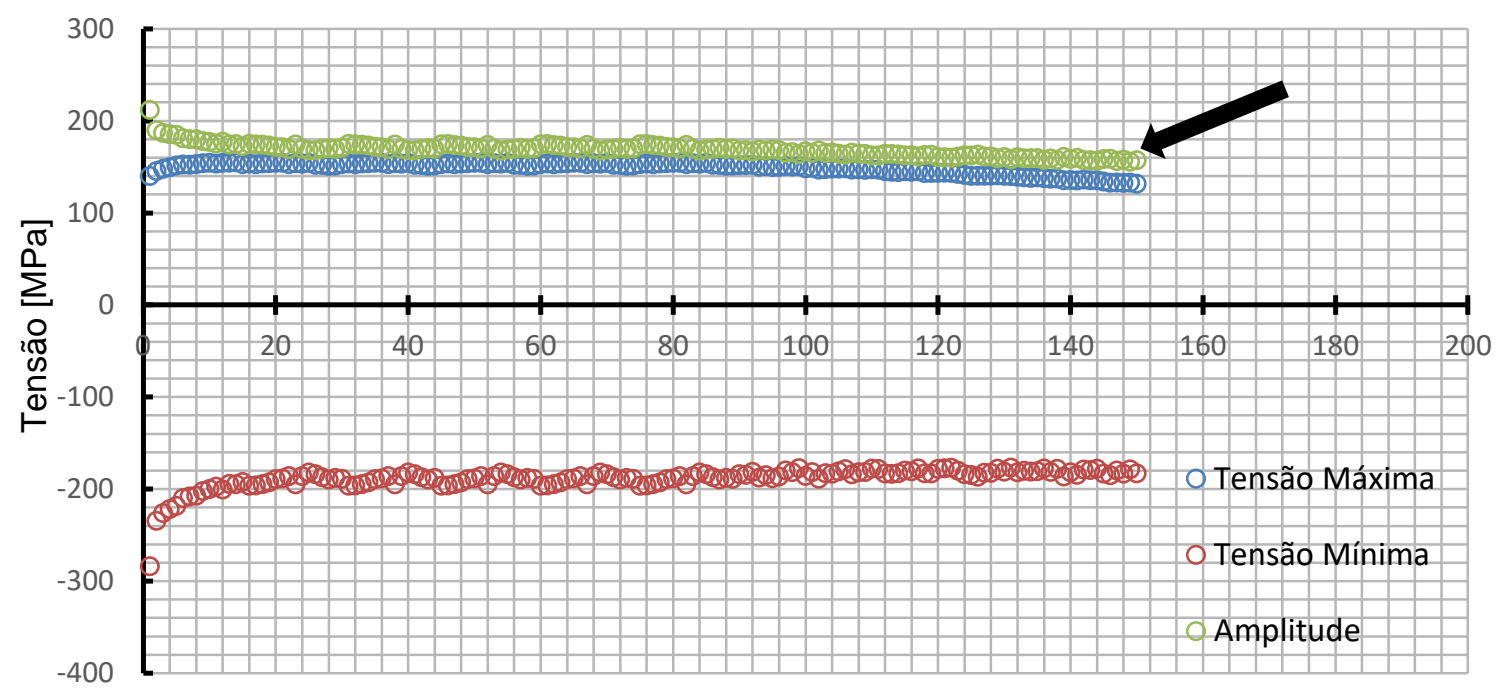

Número de ciclos

Figura 35: Evolução das tensões durante os ciclos térmicos (FFC-CP4) falha por fratura em 147 ciclos.

Fonte: Produção do próprio autor. 


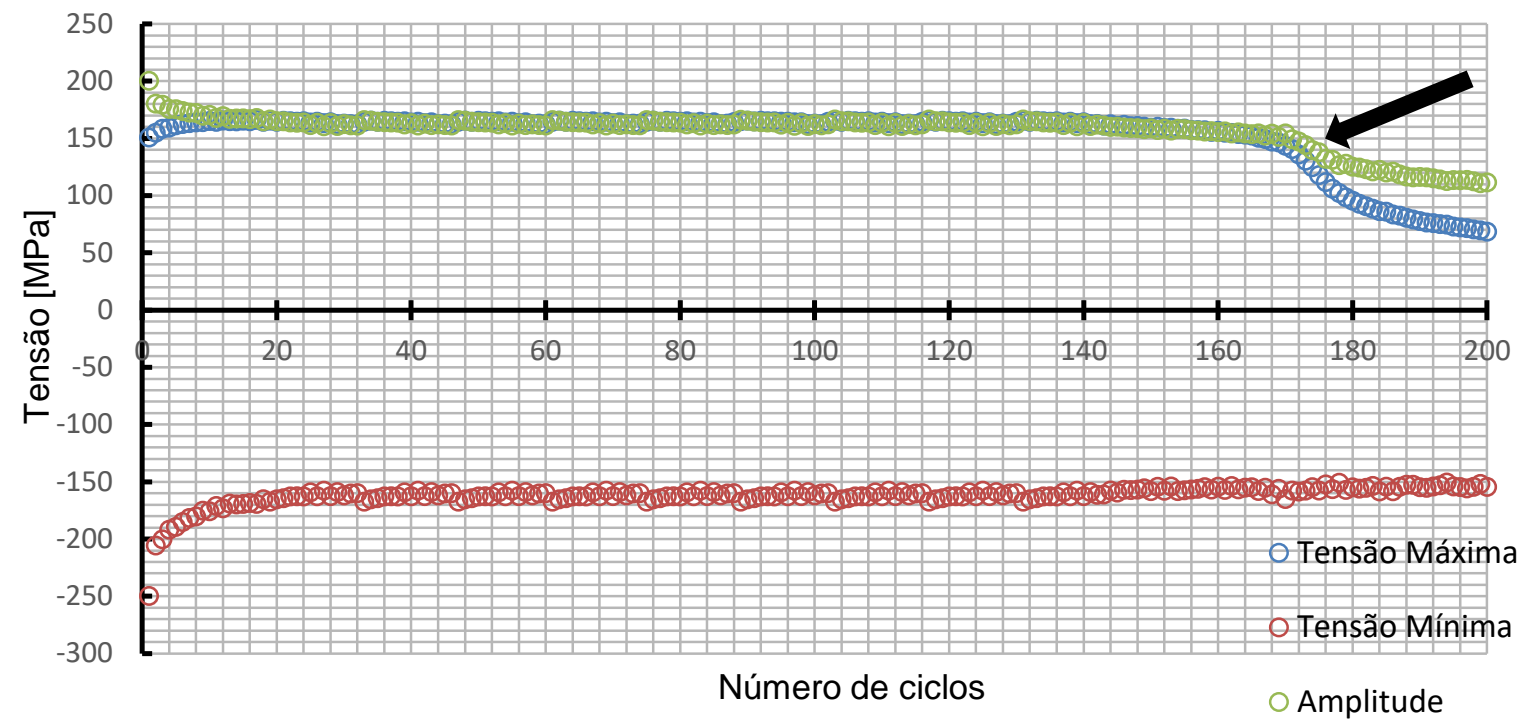

Figura 36: Evolução das tensões durante os ciclos térmicos (FFC-CP5) falha por início de queda em 170 ciclos.

Fonte: Produção do próprio autor.

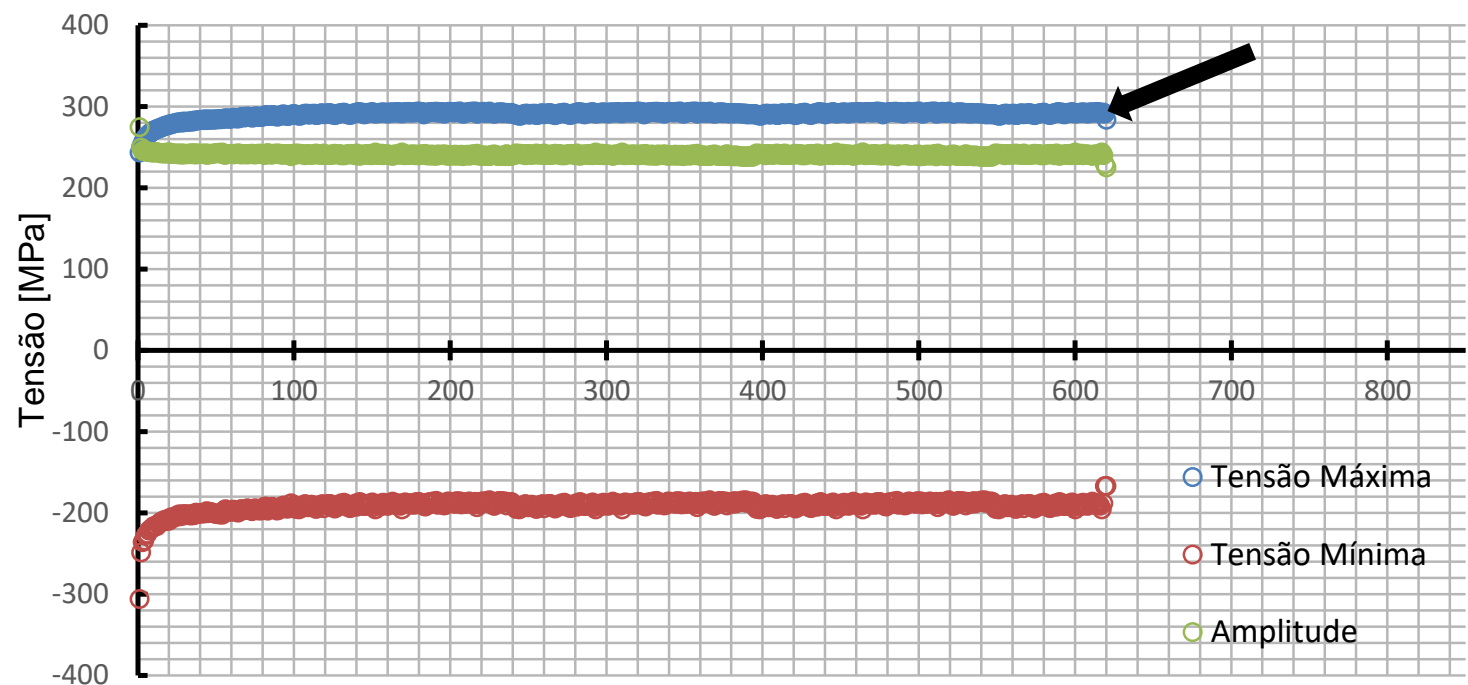

Número de ciclos

Figura 37: Evolução das tensões durante os ciclos térmicos (FFV-CP1) falha por fratura em 610 ciclos.

Fonte: Produção do próprio autor. 


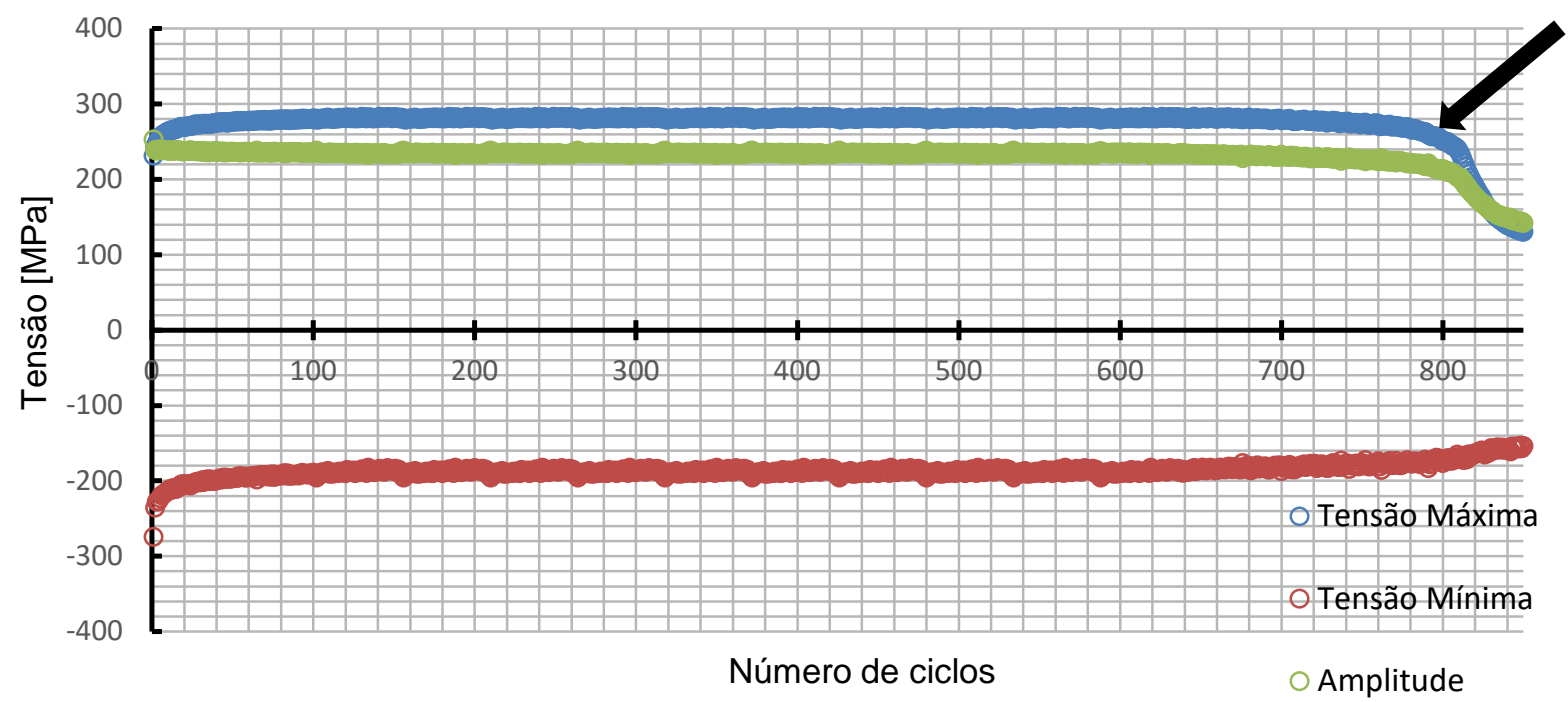

Figura 38: Evolução das tensões durante os ciclos térmicos (FFV-CP2) falha por inicio de queda em 800 ciclos.

Fonte: Produção do próprio autor.

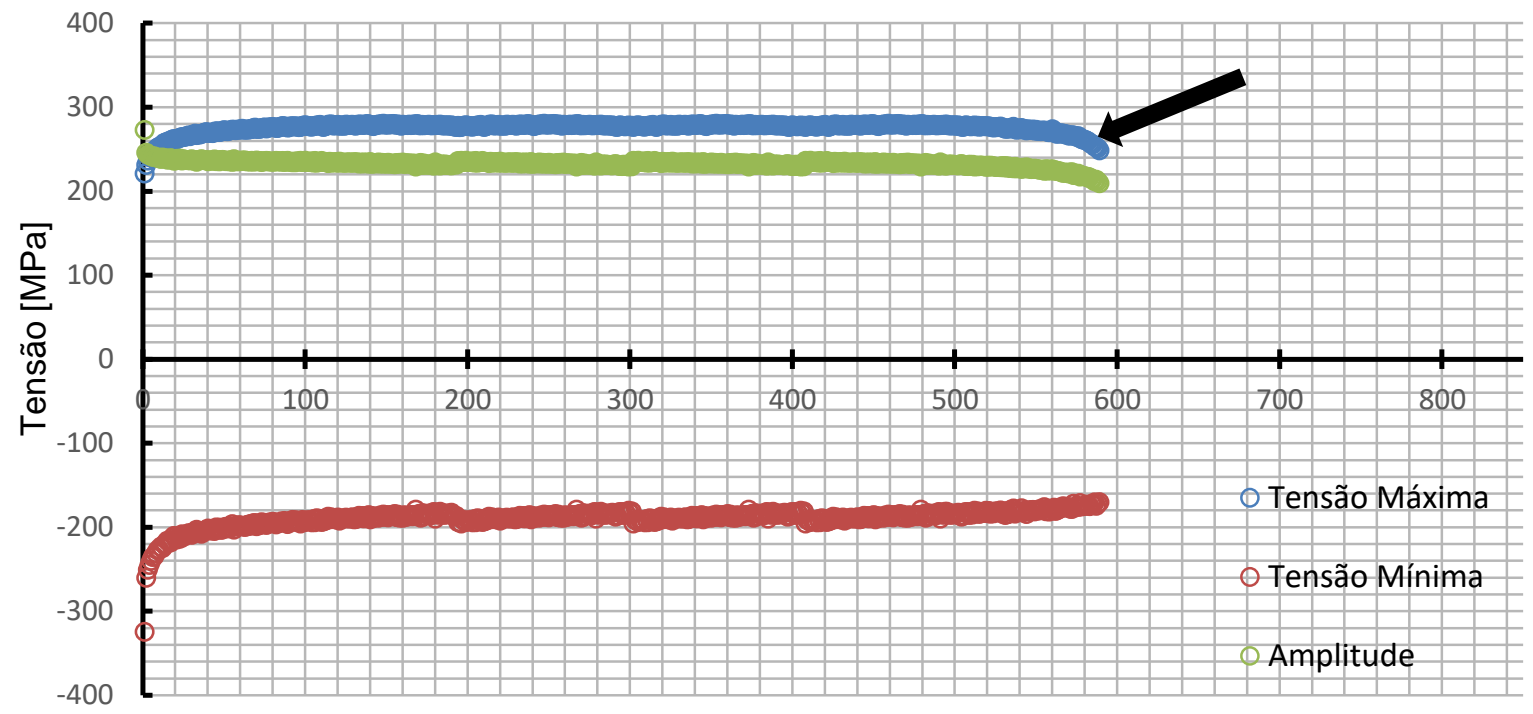

Número de ciclos

Figura 39: Evolução das tensões durante os ciclos térmicos (FFV-CP3) falha por fratura em 585 ciclos.

Fonte: Produção do próprio autor. 


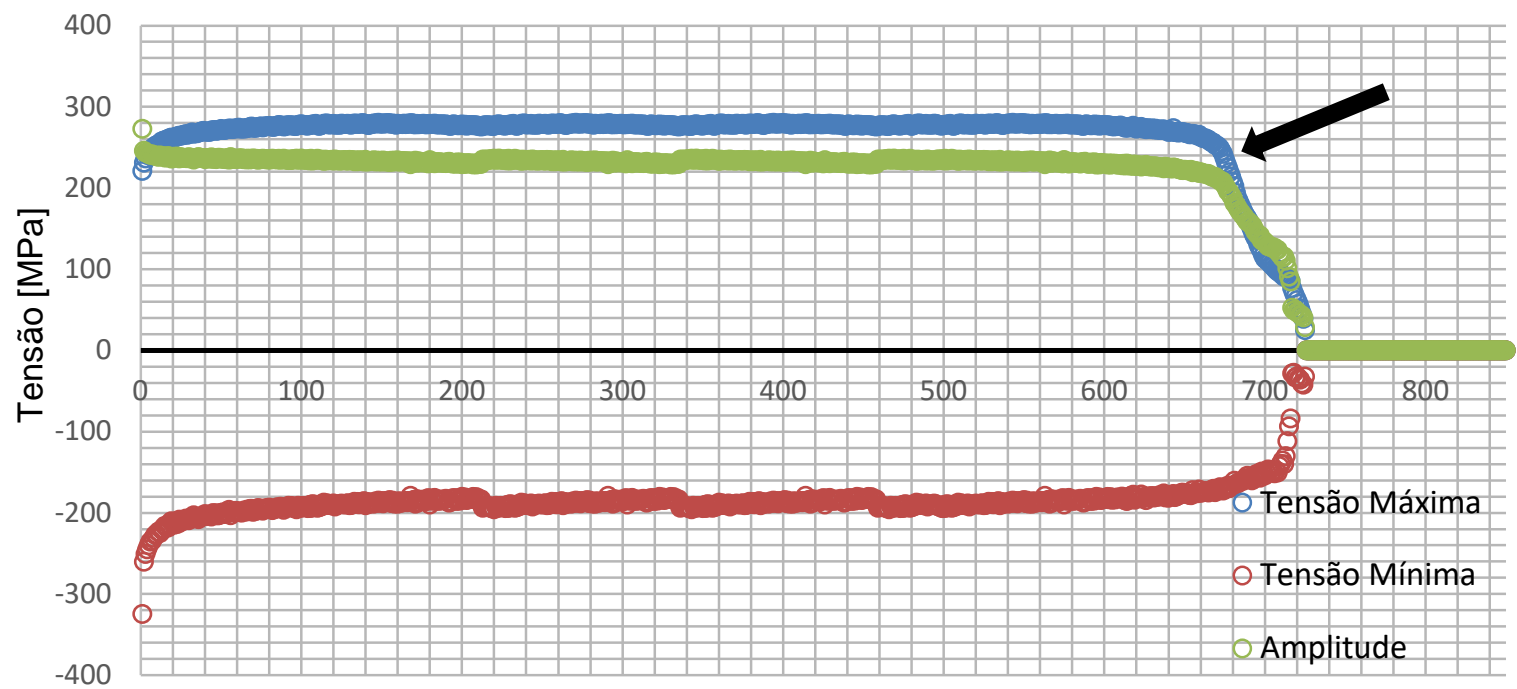

Número de ciclos

Figura 40: Evolução das tensões durante os ciclos térmicos (FFV-CP4) falha por início de queda em 660 ciclos.

Fonte: Produção do próprio autor.

Como foi observado no caso dos corpos de prova de FFC (CP1, CP3, CP4) e FFV (CP1, CP3), a fratura acontece de forma brusca, isto é, sem queda gradual da tensão, como no caso dos corpos de prova de FFC (CP2, CP5) e FFV (CP2, CP4). Este fenômeno é decorrente da posição do ponto de nucleação da trinca e o de fixação do extensômetro onde pode ser observado na Figura 41.

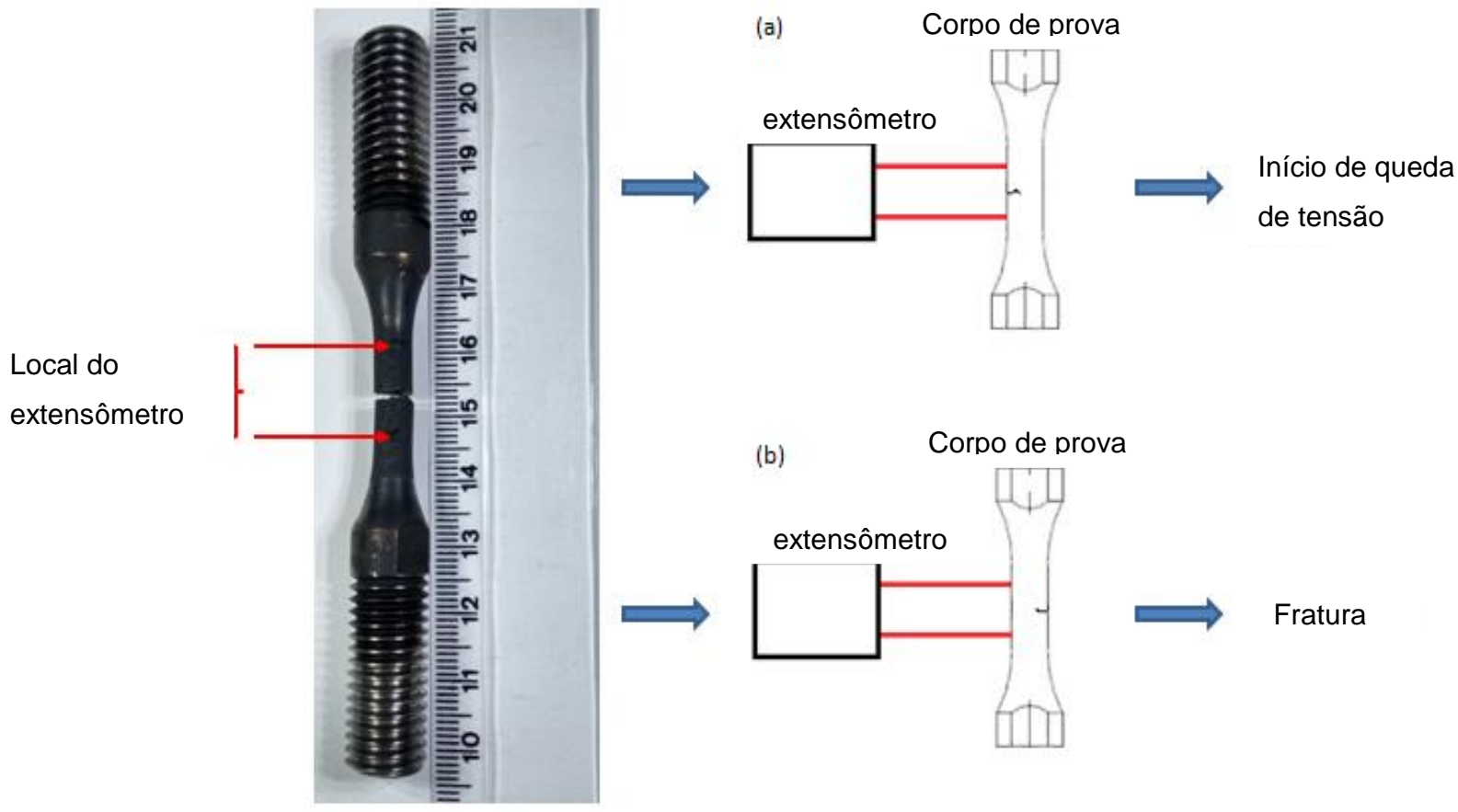

Figura 41: Detalhamento de posição do extensômetro e crescimento de trinca (a) início da trinca em face (b) início da trinca ao lado posterior.

Fonte: Produção do próprio autor. 
Quando a boca da trinca fica próxima ao ponto de fixação do extensômetro é observada uma queda gradual da tensão, pois a medida que a trinca cresce com a aplicação dos ciclos térmicos, a flexibilidade elástica do corpo de prova aumenta e como resultado a carga necessária para manter a condição de restrição total é cada vez menor. Quando a trinca se inicia longe do ponto de fixação do extensômetro, este não sente a alteração na flexibilidade elástica do corpo de prova e assim a trinca progride a uma tensão constante até muito próximo da ruptura final, que acontece de forma abrupta. Assim, parece correto a adoção de um critério de falha de $10 \%$ da máxima tensão obtida na vida do referido corpo de prova, conforme prescrito pela norma ASTM E236 [54]. A seta nos gráficos das Figura 3240, que apresentam a evolução das tensões, indica exatamente o ciclo onde este critério de falha é atendido. Esta mesma observação foi realizada por GHODRAT 2013 [7].

A Tabela 10 mostra as tensões máximas obtidas no ensaio de FTM para cada corpo de prova e, Tabela 11 a vida em ciclos para cada um dos mesmos.

Tabela 10: Tensões máxima obtidas durante o ensaio de FTM

\begin{tabular}{ccc}
$\mathbf{C P}$ & Tensão Máxima [MPa] FFC & Tensão Máxima [MPa] \\
& & FFV \\
$\mathbf{1}$ & 182 & 281 \\
$\mathbf{2}$ & 175 & 298 \\
$\mathbf{3}$ & 160 & 279 \\
$\mathbf{4}$ & 171 & 278 \\
$\mathbf{5}$ & 165 & - \\
\hline Média & 171 & 284
\end{tabular}

Fonte: Produção do próprio autor.

Tabela 11: Vida em FTM dos ferros fundidos cinzento e vermiculares.

\begin{tabular}{|c|c|c|c|c|c|}
\hline Material & CP & Ciclos & $\begin{array}{l}\text { Critério de } \\
\text { Falha }\end{array}$ & $\begin{array}{l}\text { Média dos } \\
\text { Ciclos }\end{array}$ & Desvio Padrão \\
\hline \multirow{5}{*}{ FFC } & 1 & 97 & Fratura & \multirow{5}{*}{128} & \multirow{5}{*}{30} \\
\hline & 2 & 108 & Inicio de queda & & \\
\hline & 3 & 116 & Fratura & & \\
\hline & 4 & 147 & Fratura & & \\
\hline & 5 & 170 & Inicio de queda & & \\
\hline \multirow{4}{*}{ FFV } & 1 & 610 & Fratura & \multirow{4}{*}{661} & \multirow{4}{*}{96} \\
\hline & 2 & 800 & Inicio de queda & & \\
\hline & 3 & 585 & Fratura & & \\
\hline & 4 & 660 & Inicio de queda & & \\
\hline
\end{tabular}

Fonte: Produção do próprio autor. 


\subsection{Análise fractografica}

As análises fractográficas foram realizadas em todos os corpos de prova após a fratura no ensaio de FTM. A Figura 42 apresenta o aspecto geral das superfícies de fratura destes corpos de prova. É possível observar que nos FFC, dada a sua baixa plasticidade em tração, estes não apresentam uma distinção entre a região de propagação estável de trinca e a região de fratura instável. Uma explicação seria a formação de múltiplas trincas internas e na superfície da secção útil, que coalescem e causam uma fratura brusca, raramente permitindo uma queda gradual da tensão. No caso do FFV, ver exemplo em detalhe da Figura 43, nos corpos de prova que não oxidaram após a fratura, foi claramente observada a região de propagação estável da trinca e que este apresenta uma maior tenacidade à fratura do que FFC. $\mathrm{Na}$ Figura 43, tem-se as regiões de nucleação de trinca $(\mathrm{N})$, propagação estável $(\mathrm{P})$ e propagação instável ou falha final $(\mathrm{F})$.

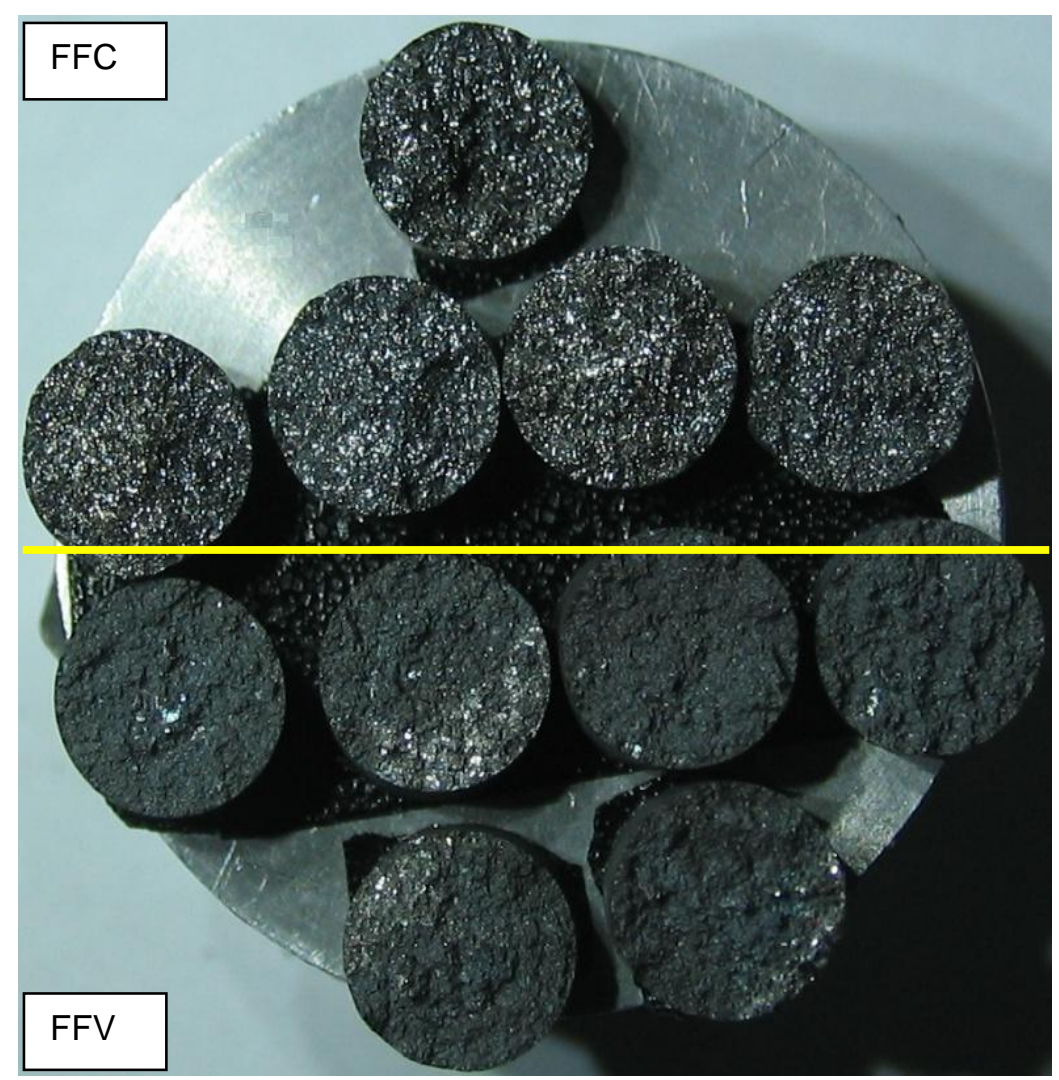

Figura 42: Análise da superfície de fratura dos ferros fundidos cinzento e vermicular após submetidos ao ensaio de FTM.

Fonte: Produção do próprio autor. 


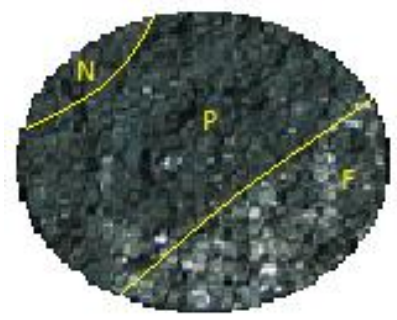

Figura 43: Aspecto macrográfico da superfície de fratura do corpo de prova após o ensaio de FTM (FFV).

Fonte: Produção do próprio autor.

As análises da superfície de fratura dos corpos de prova mostraram que o modo de fratura foi essencialmente frágil por clivagem, ver Figura 44.

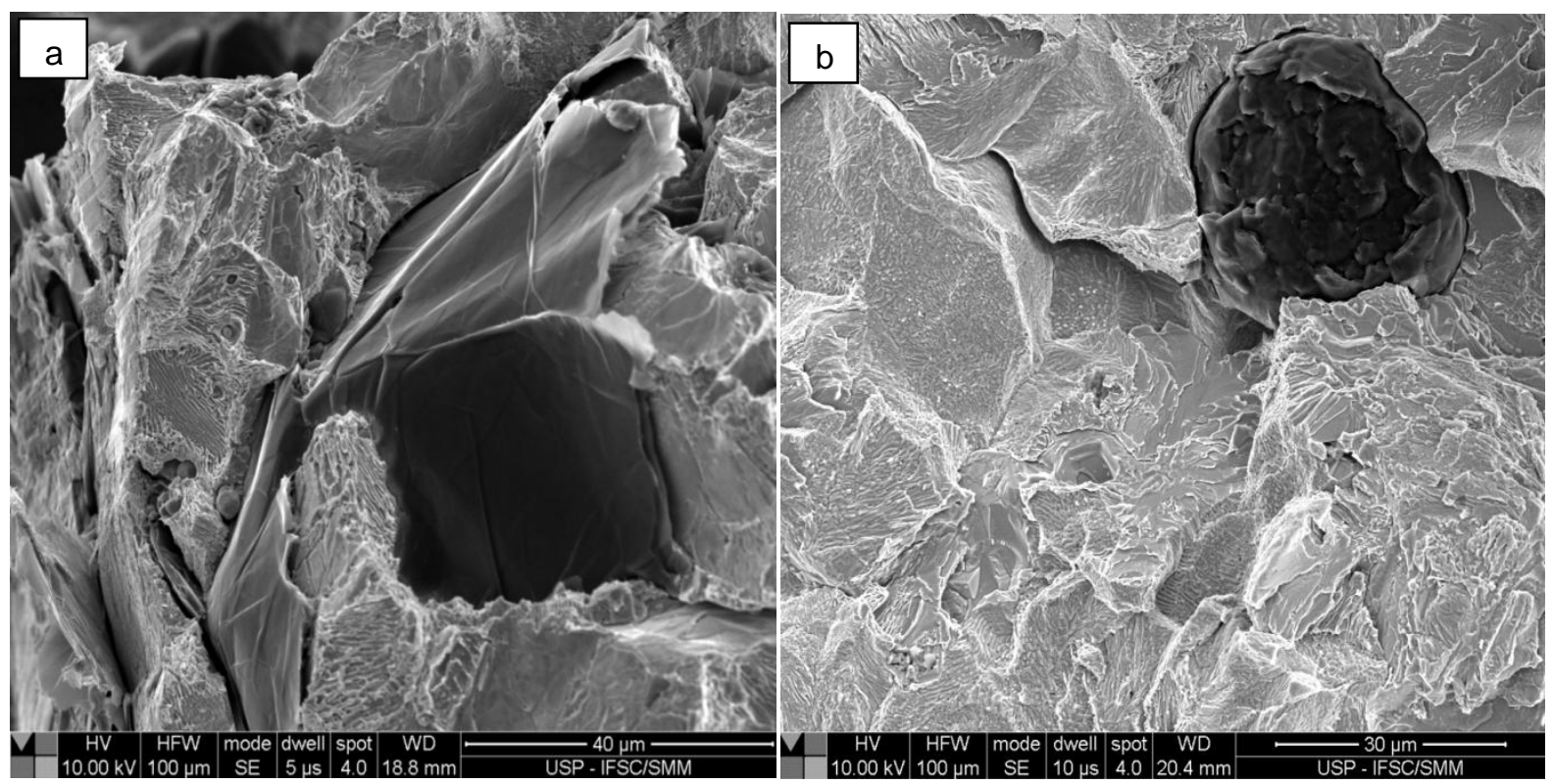

Figura 44: Superfície de fratura observada em MEV do ferro fundido (a) cinzento e (b) vermicular.

Fonte: Produção do próprio autor.

$\mathrm{Na}$ superfície de fratura da Figura 44 (a) é possível observar placas de grafita e pequenas regiões de fratura da matriz, sendo que a trinca tende a se propagar pela interface da matriz/grafita, onde a energia da propagação aumenta se tornando a principal responsável pela resistência dos ferros fundidos cinzentos e vermiculares.

As análises de fratura nos ferros fundidos vermiculares na Figura 44 (b) são similares ao do FFC. Conforme observado por GUESSER [20], a fratura neste tipo de FF envolve uma deformação plástica e causa a ruptura entre a interface grafita/matriz, a diferença que envolve a fratura é que se desenvolve em maior parte pela grafita, já que o esqueleto (morfologia) de grafita não é continuamente bidimensional, isso acaba exigindo menor energia para que 
produza ruptura nas interfaces grafita/matriz. Assim pode se obter várias microtrincas em toda a microestrutura do ferro fundido vermicular até que várias trincas se encontram tornando uma trinca principal que posteriormente chegue a fratura total, esse fenômeno pode ser observado na Figura 43, em que para o ferro fundido vermicular pode se observar em sua superfície, a fratura dúctil e frágil comparando com o ferro fundido cinzento que se demonstrou apenas frágil.

Segundo a norma SAE J1887/2002, a porcentagem de nodularidade no ferro fundido vermicular pode variar até $20 \%$, esta presença dos nódulos de grafita mostrado na Figura 43 (b) também auxilia no bloqueio de propagação de trincas e na transição dúctil/frágil.

O dano pelos ciclos termomecânicos em ferros fundidos, são causados logo nos primeiros ciclos, ocorrendo a desmoldagem da grafita e matriz e assim, ocorre o surgimento de micro trincas devido a altas tensões trativas que acontecem na parte trativa do ciclo, permitindo a continua oxidação das frentes da trinca como observado na Figura 45 (a).

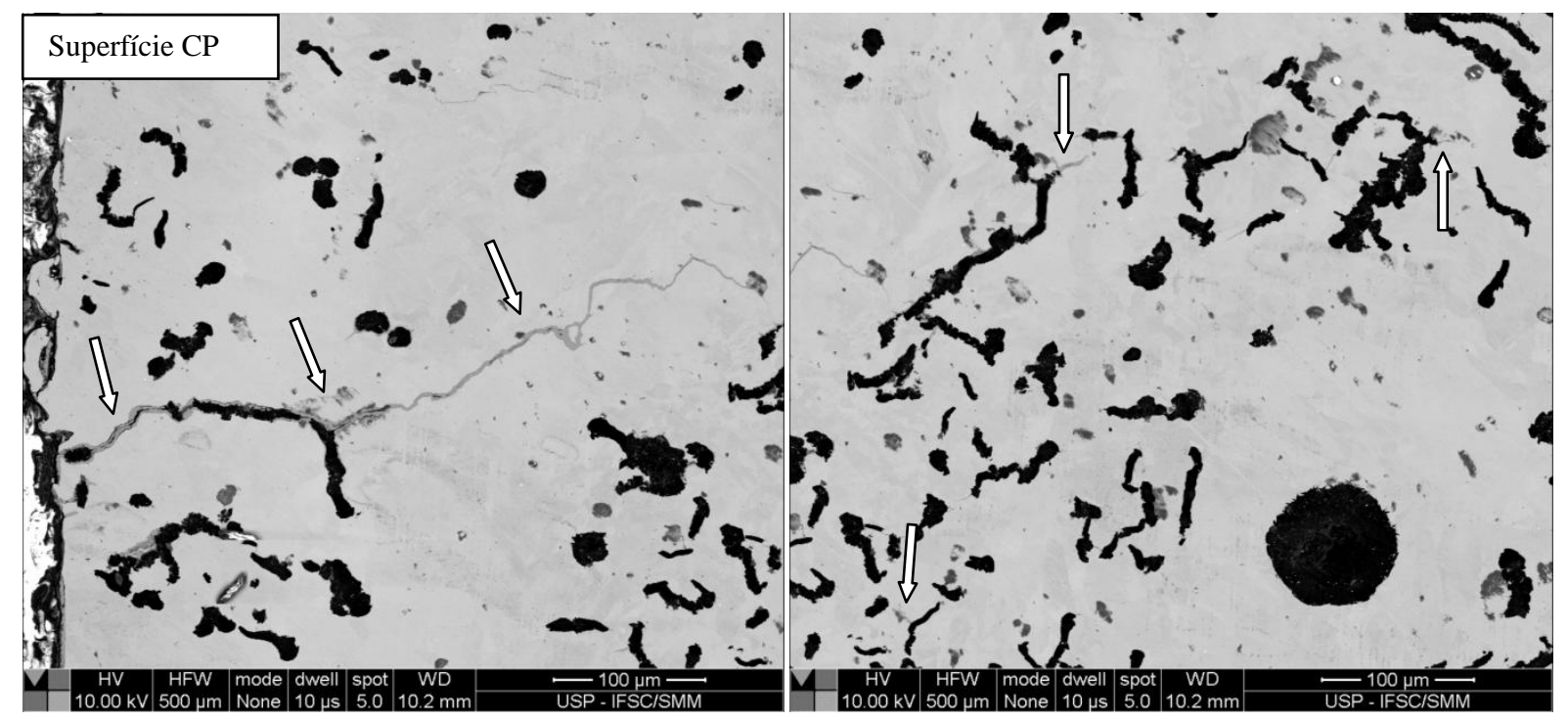

(a) 


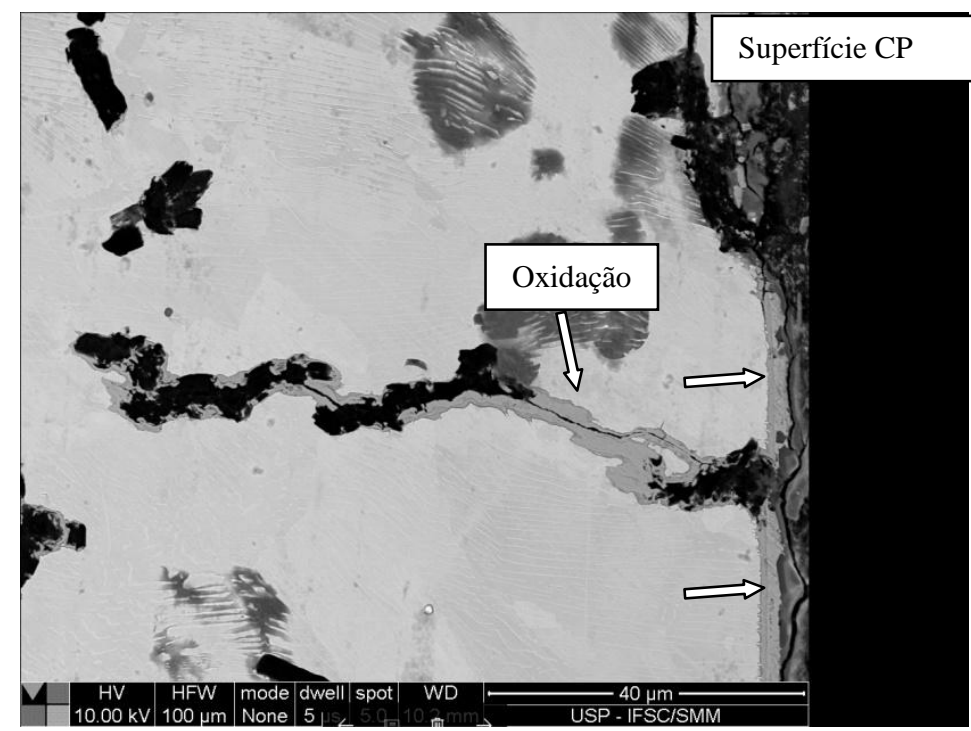

(b)

Figura 45: Análise de oxidação exposto ao ciclo térmico em (a) FFV-CP 2, 800 ciclos e (b) FFC-CP5, 170 ciclos, podendo ser notado à oxidação durante a propagação de trinca. Fonte: Produção do próprio autor.

Durante o patamar em alta temperatura, a grafita da superfície do corpo de prova começa a oxidar imediatamente ao primeiro ciclo, ocorrendo à perda de carbono gradualmente com o decorrer dos ciclos posteriores, juntamente com esse fenômeno, a cada ciclo várias trincas começam a se nuclear, sendo sua propagação estável ou instável levando a fratura do componente. Estas trincas auxiliam a entrada do oxigênio no material reduzindo a ligação entre a matriz e a grafita [36,40], sendo assim um processo auto catalítico.

A quantidade da grafita afeta fortemente a vida em fadiga termomecânica e contribui no tempo de oxidação, na Figura 45 (b) é possível observar que com muitas partículas de grafita na superfície ocasionaram uma camada de oxidação, fornecendo caminhos favoráveis para o transporte de oxigênio através do material auxiliando também a propagação das trincas já existentes mostrados na Figura 46.

Nas Figuras 47 e 48 são apresentadas imagens de microscopia ótica realizadas nos corpos de prova que foram ensaiados por FTM no material FFV. Pode-se observar a propagação da trinca durante toda a extensão da matriz perlítica pelo ponto $\mathrm{A}$ até o ponto $\mathrm{B}, \mathrm{e}$ também iniciação de trincas indicado pelas setas em azul. 


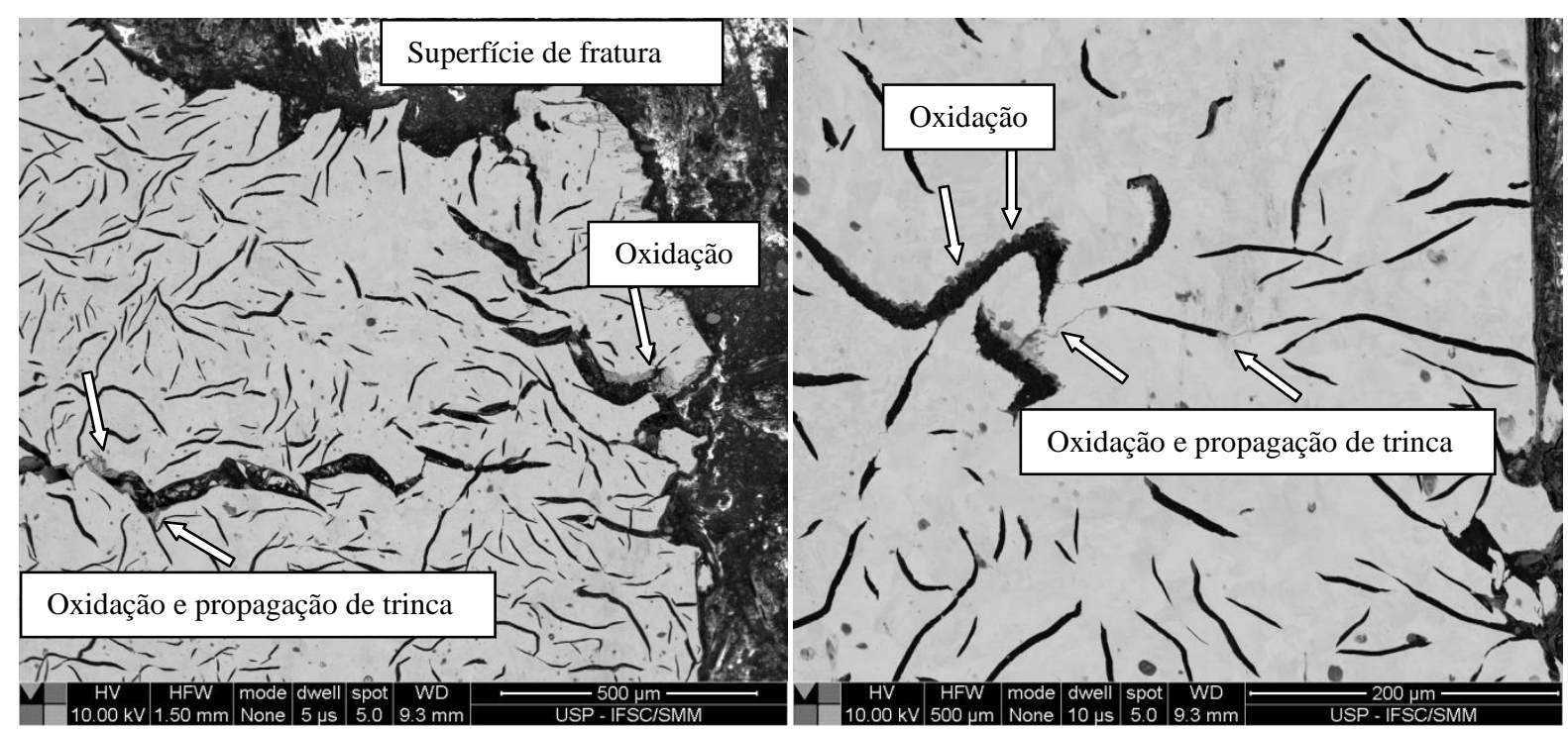

Figura 46: Análise microestrutural do FFC fraturado após 170 ciclos, onde se nota à oxidação durante a propagação de trinca.

Fonte: Produção do próprio autor.

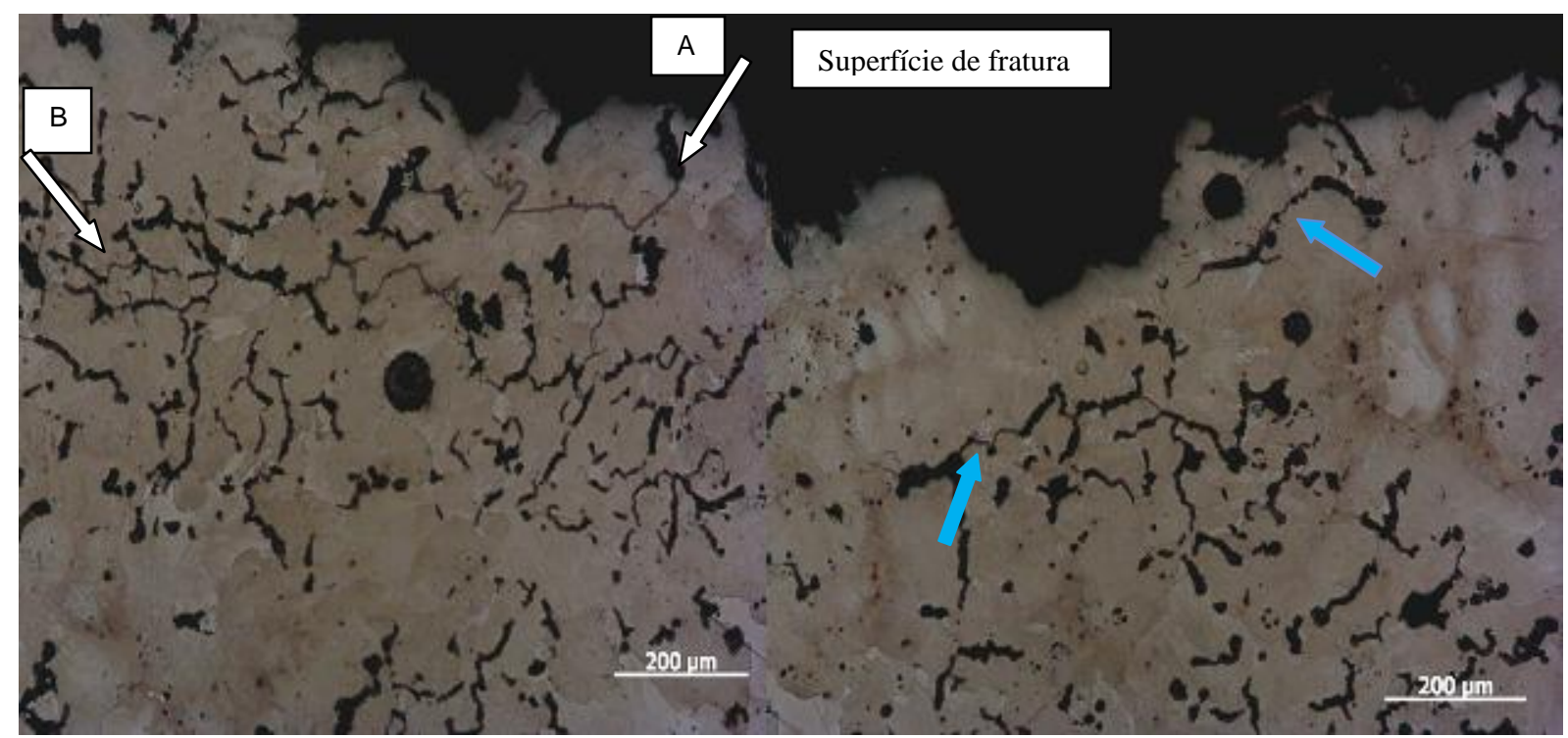

Figura 47: Perfil de trinca obtido no ensaio por FTM com amplitude de deformação de 0,577 $\%$, após 800 ciclos onde ocorreu a falha do corpo de prova pelo critério de $10 \%$ da tensão máxima (FFV-CP2).

Fonte: Produção do próprio autor. 


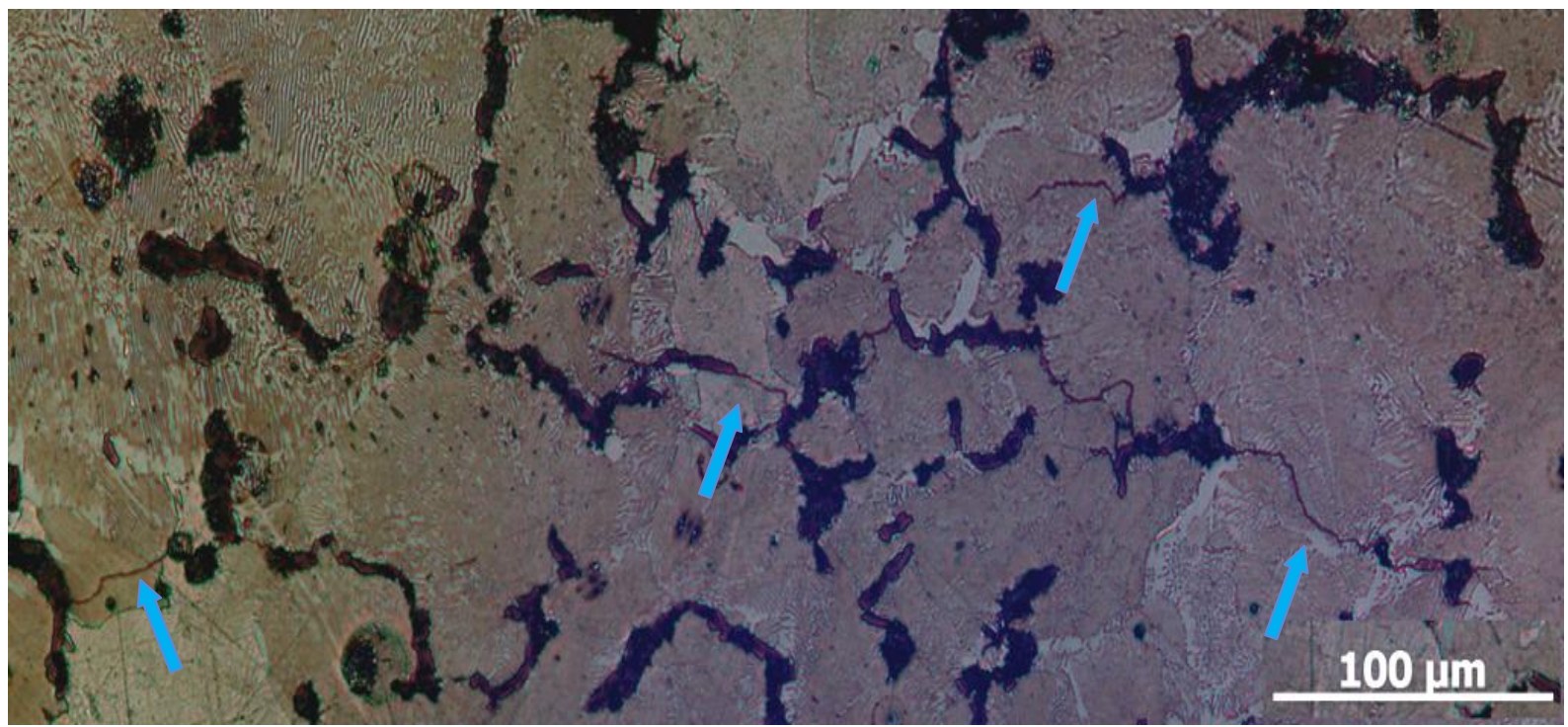

Figura 48: Detalhe de trincas em setas por toda extensão na matriz perlítica no FFV. Fonte: Produção do próprio autor.

Nas Figuras 49 e 50 observam-se as imagens de microscopia ótica realizadas nos corpos de prova que foram ensaiados por FTM no material FFC.

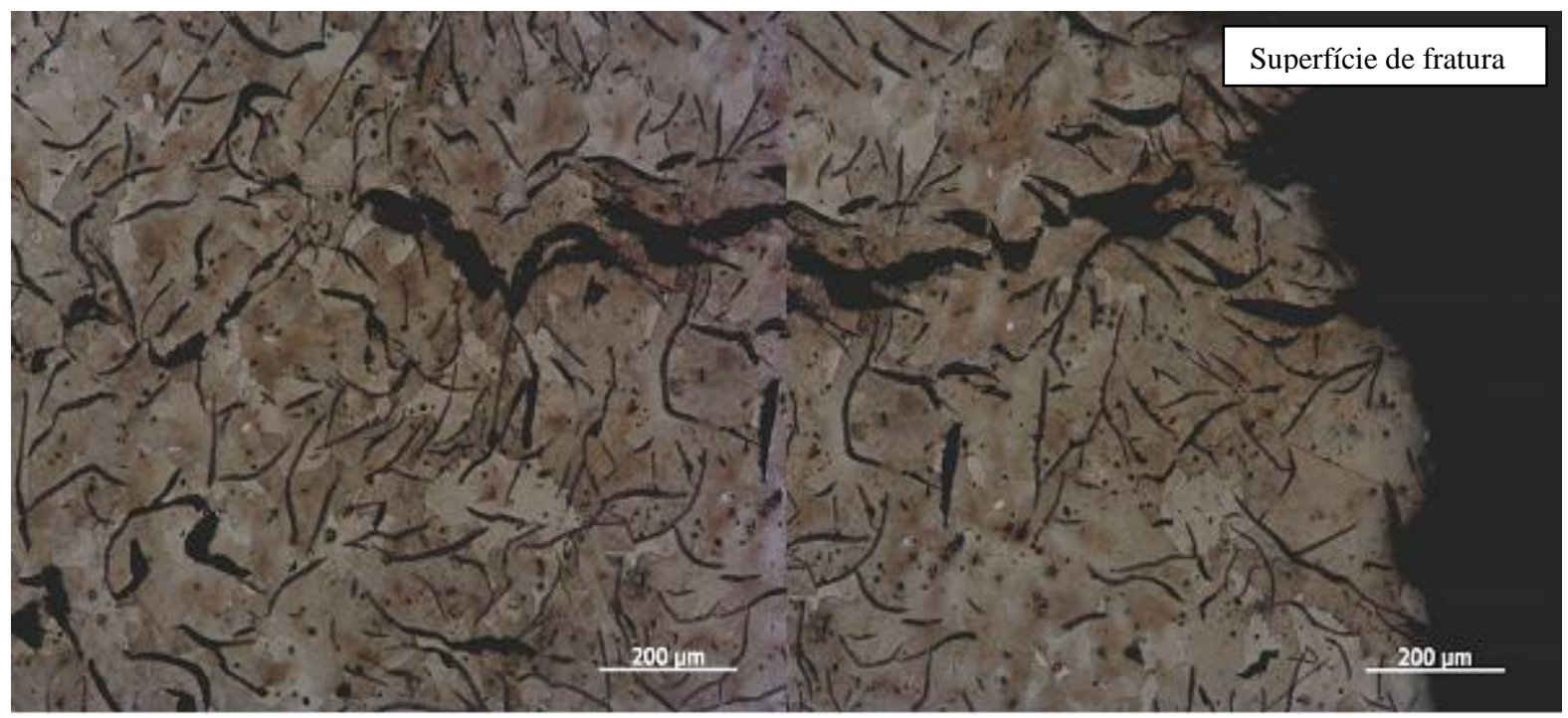

Figura 49: Perfil de trinca obtido no ensaio por FTM com amplitude de deformação de $0,6 \%$, após 170 ciclos.

Fonte: Produção do próprio autor. 


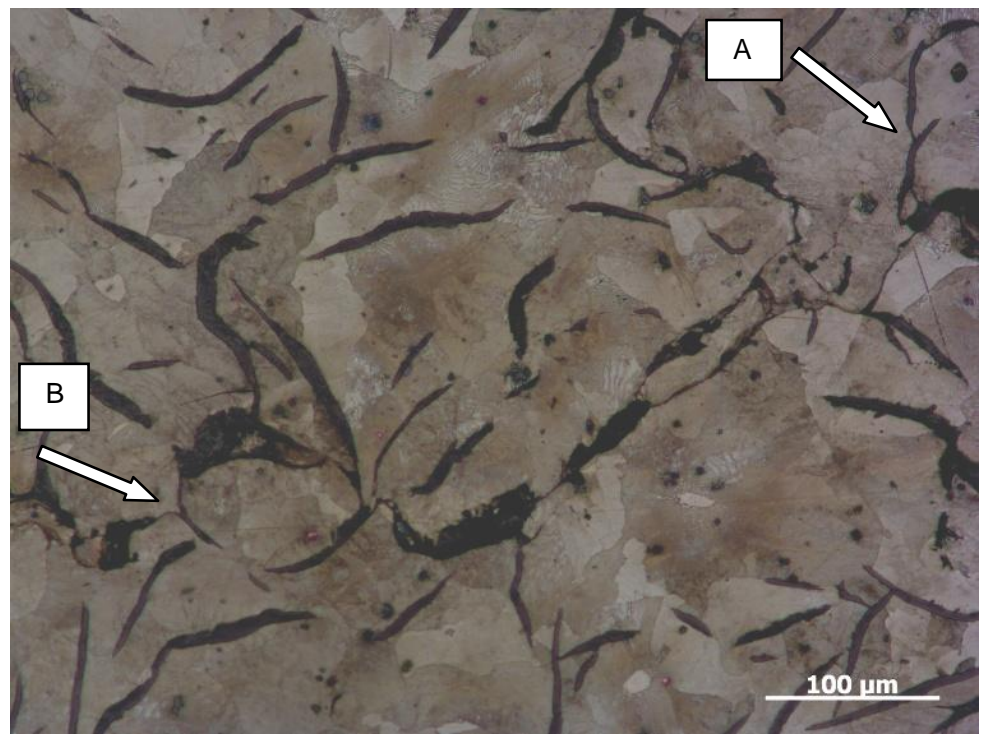

Figura 50: Propagação de trinca indicado pelas letras A e B, no ferro fundido cinzento submetido a 170 ciclos, CP-2.

Fonte: Produção do próprio autor.

Na Figura 49 é apresentado a propagação de trinca a partir da parada do ensaio de FTM, onde a tensão máxima chegou em torno de $60 \mathrm{MPa}$ após 170 ciclos, sem a ocorrência de fratura total do corpo de prova, podendo ser observada pelo corte transversal a iniciação da trinca a partir da superfície, na Figura 50 observa-se propagação de trinca indicada pelas letras A e B.

Pode-se observar que em ambos os materiais FFC e FFV, foram encontradas microtrincas secundarias, no modo transgranular e intergranular, pois, o caminho percorrido pela trinca se dá inicialmente através das partículas de grafita, essa formação de microtrincas junto à interface grafita/matriz é considerada o início do processo de fratura.

O modo de propagação da trinca depende fortemente da morfologia da grafita, no caso do ferro fundido cinzento, foram observadas menores porcentagens de trincas secundarias, devido a sua microestrutura ser formada por um esqueleto continuo favorecendo a propagação e resultando em fratura frágil.

Para o ferro fundido vermicular foi encontrado maior porcentagem de microtrincas secundarias, devido a sua morfologia conter estrutura bidimensional, esta característica se resulta em retardo, servindo como bloqueio de sua propagação. Por esse fenômeno, ocorre a propagação de trincas individuais próximas, formando uma trinca principal que posteriormente irá conduzir à fratura total. 


\section{CONCLUSÕES}

O objetivo principal deste trabalho foi o de avaliar a vida em fadiga termomecânica de dois tipos de ferros fundidos utilizados na fabricação de componentes de motores automotivos.

As seguintes conclusões são apresentadas.

* Nas análises metalográficas após os ensaios onde a trinca se estendeu na intergranular quanto na transgranular, pode-se notar que a matriz não interfere em sua propagação e sim na morfologia da grafita.

* Dos resultados dos ensaios de tração nas temperaturas de $50^{\circ}$ e $420{ }^{\circ} \mathrm{C}$ observou-se redução nos parâmetros de resistência mecânica, isto é, nos valores da tensão máxima, limite de escoamento, limite de ruptura e módulo de elasticidade.

* A deformação plástica no foi similar para os dois tipos de ferros fundidos, mas o FFC apresentou vida muito inferior ao FFV, mostrando que para uma mesma amplitude de deformação plástica o dano no FFC é muito maior, sendo isso devido a grande diferença de morfologia das grafitas, pois ambas as matrizes são constituídas primariamente de perlita. A morfologia em flocos/lamelas no FFC favorece a múltipla iniciação e a propagação instável de trincas.

* O primeiro ciclo de temperatura foi observado ser diferente dos demais, sendo que neste acontece uma grande quantidade de deformação plástica em compressão e como consequência ocorre alívio de tensão. Neste trabalho, foi observado que o alivio de tensões acontece em duas etapas, a primeira a partir do atendimento da máxima tensão em compressão e a segunda durante o patamar de temperatura.

* Foi observado que, tanto para o ferro fundido cinzento quanto para ferro fundido vermicular não ocorreu a diminuição significativa da deformação plástica com o aumento do número de ciclos.

* Pela análise da superfície de fratura, observou-se que nos ferros fundidos cinzentos a fratura, quase que majoritariamente, ocorre nos veios de grafita, seja pela fratura da grafita ou da interface grafita/matriz. Dada a oxidação superficial na região de propagação de trinca, não foi possível a observância de estrias de fadiga, que seria 
esperado na perlita. Na fratura final (fratura instável) esta foi quase sempre dúctil por coalescencia de microvazios na matriz, com pouca ocorrência de fratura por clivagem. 


\section{SUGESTÕES PARA TRABALHOS FUTUROS}

Sugestões para futuros trabalhos são apresentados no sentido de complementar a Dissertação presentemente desenvolvida:

$>$ Explorar o efeito da fadiga termomecânica no que diz respeito à oxidação e evolução microestrututal durante o aumento dos ciclos nos dois materiais estudados.

$>\quad$ Avaliar o efeito do tempo de "Dwell" em alta temperatura, mudando seu tempo em permanência. 


\section{REFERÊNCIAS BIBLIOGRAFICAS}

[1] HALLSTEIN, R. et al. Thermal-mechanical fatigue behaviour of vermicular cast iron. In: ICM 8: Eighth International Conference on the Mechanical Behaviour of Materials. p. 301-306, 1999.

[2] REMY, L. Fatigue and thermomechanical fatigue at high temperature. KH JÜRGEN BUSCHOW et al, p. 2866-2877, 2001.

[3] TRAMPERT, Stefan; GOCMEZ, Taner; PISCHINGER, Stefan. Thermomechanical fatigue life prediction of cylinder heads in combustion engines. Journal of Engineering for Gas Turbines and Power, v. 130, n. 1, p. 012806, 2008.

[4] LÖHE, D.; BECK, T.; LANG, K. H. Important aspects of cyclic deformation, damage and lifetime behaviour in thermomechanical fatigue of engineering alloys. In: 5th International Conference on Low Cycle Fatigue. p. 161-175, 2004.

[5] MERCHANT, Harish D. Oxidation kinetics of iron-carbon base alloys. Oxidation of Metals, v. 2, n. 2, p. 145-153, 1970.

[6] BUNI, S. Y.; RAMAN, N.; SESHAN, S. Effect of structural features on erosion resistance of cast irons. Tribology Letters, v. 2, n. 1, p. 99-111, 1996.

[7] GHODRAT, S. Thermo-mechanical fatigue of compacted graphite iron in diesel engine components. Tese de Doutorado. TU Delft, Delft University of Technology. 2013.

[8] DAVIS, Joseph R. et al. (Ed.). ASM specialty handbook: cast irons. ASM international, 1996.

[9] RUNDMAN, K. B.; IRONS, Cast. Encyclopedia of Materials. Science and Technology, p. 1003-1010, 2008. 
[10] SANTOS, A B. de S.; BRANCO, Carlos HC. Metalurgia dos ferros fundidos cinzentos e nodulares. IPT, v. 100, p. 232-236, 1989.

[11] CALLISTER, William D.; RETHWISCH, David G. Fundamentals of materials science and engineering: an integrated approach. John Wiley \& Sons, 2012.

[12] VELICHKO, A. Quantitative 3D characterization of graphite morphologies in cast iron using FIB microstructure tomography. 2008.

[13] Knowledge Article, www.Key-to-Steel.com: Cast irons.

[14] DAVIS, J. R. et al. (Ed.). ASM specialty handbook: cast irons. ASM international, 1996.

[15] MINKOFF, Isaac. The physical metallurgy of cast iron. Wiley, 1983.

[16] LUX, B. Nucleation of Eutectic Graphite in Inoculated Gray Iron by Saltlike Carbides. Modern Casting, v. 54, p. 41-47, 1964.

[17] RUNDMAN, K. B.; IRONS, Cast. Encyclopedia of Materials. Science and Technology, p. 1003-1010, 2008.

[18] DURAND-CHARRE, M. Microstructure of steels and cast irons. Springer Science \& Business Media, 2004.

[19] SHAO, S.; DAWSON, S.; LAMPIC, M. The mechanical and physical properties of compacted graphite iron. Materialwissenschaft und Werkstofftechnik, v. 29, n. 8, p. 397411, 1998.

[20] GUESSER, Wilson Luiz. Propriedades mecânicas dos ferros fundidos. Blucher, 2009.

[21] LOHE, D. Properties of Vermicular Cast Iron at Mechanical and Thermal-Mechanical Loading. 8th. In: Machining Workshop for Powertrain Materials, Darmstadt. 2005. 
[22] ASTM A 247: AMERICAN SOCIETY FOR TESTING AND MATERIALS - Standard Test Method for Evaluating the Microstructure of Graphite in Iron Castings. Philadelphia, v.01.02, 1998.

[23] GRUZLEWSKY, J. E. Microstructure development during metalcasting. AFS, 2000.

[24] REMY, L. Fatigue and thermomechanical fatigue at high temperature. KH JÜRGEN BUSCHOW et al, p. 2866-2877, 2001.

[25] DA FM GOMES, O.; PACIORNIK, S. Automatic classification of graphite in cast iron. Microscopy and Microanalysis, v. 11, n. 04, p. 363-371, 2005.

[26] DAVIS, Joseph R. et al. (Ed.). ASM specialty handbook: heat-resistant materials. Asm International, 1997.

[27] DAWSON, S.; SCHROEDER, T. Practical applications for compacted graphite iron. AFS Transactions, v. 47, n. 5, p. 1-9, 2004.

[28] LANGMAYR, Franz; ZIEHER, Dipl-Ing Franz; LAMPIC, Milan. Thermomechanik von Gusseisen für Zylinderköpfe. MTZ-Motortechnische Zeitschrift, v. 65, n. 4, p. 298-303, 2004.

[29] DAWSON, Steve. Process control for the production of compacted graphite iron. In: 106th AFS Casting Congress, Kansas City. p. 4-7. 2002.

[30] CHIAVERINI, Vicente. Aços e ferros fundidos. Abm, 1979.

[31] COLPAERT, Hubertus. Metalografia dos produtos siderúrgicos comuns. In: Metalografia dos produtos siderúrgicos comuns. Edgard Blucher, 1994.

[32] ZIEGLER, K. R.; WALLACE, J. F. The Effect of Matrix Structure and Alloying on the Properties of Compacted Graphite Iron.(Retroactive Coverage). Transactions of the American Foundrymen's Society., v. 92, p. 735-748, 1984. 
[33] CHAO, C. G.; LUI, T. S.; HON, M. H. A study of tensile properties of ferritic compacted graphite cast irons at intermediate temperatures. Journal of materials science, v. 24, n. 7, p. 2610-2614, 1989.

[34] TRAMPERT, Stefan; GOCMEZ, Taner; PISCHINGER, Stefan. Thermomechanical fatigue life prediction of cylinder heads in combustion engines. Journal of Engineering for Gas Turbines and Power, v. 130, n. 1, p. 012806, 2008.

[35] ASM Metals Handbook, Volume 19, Fatigue and Fracture. Thermal and Thermomechanical Fatigue of Structural Alloys, ASM International, United States of America, 1313-1402. 1996.

[36] BROOKS, Charlie R.; CHOUDHURY, Ashok. Metallurgical failure analysis. McGrawHill, Inc.(USA), 1993, p. 409, 1993.

[37] DIETER, G. E.; SCHMIDT, L. C. Engineering design. New York: McGraw-Hill, 2013.

[38] BATHIAS, Claude; PINEAU, André (Ed.). Fatigue of materials and structures: application to design. John Wiley \& Sons, 2013.

[39] RIEDLER, Martin et al. Lifetime simulation of thermo-mechanically loaded components. Meccanica, v. 42, n. 1, p. 47-59, 2007.

[40] SEIFERT, T.; RIEDEL, H. Mechanism-based thermomechanical fatigue life prediction of cast iron. Part I: Models. International Journal of Fatigue, v. 32, n. 8, p. 1358-1367, 2010.

[41] ZIEHER, F.; LANGMAYR, F. 'Engine Simulation in View of Reduced Development Time. Technical, Paper Code: F02V081, AVL List GmbH, Austria, 2002.

[42] MERCHANT, H. D. Oxidation kinetics of iron-carbon base alloys. Oxidation of Metals, v. 2, n. 2, p. 145-153, 1970. 
[43] BUNI, S. Y.; RAMAN, N.; SESHAN, S. The role of graphite morphology and matrix structure on low frequency thermal cycling of cast irons. Sadhana, v. 29, n. 1, p. 117-127, 2004.

[44] SEIFERT, T.; RIEDEL, H. Mechanism-based thermomechanical fatigue life prediction of cast iron. Part I: Models. International Journal of Fatigue, v. 32, n. 8, p. 1358-1367, 2010.

[45] ASTM A476/476M-00: AMERICAN SOCIETY FOR TESTING AND MATERIALS Standard Specification for Ductile Iron Castings for Paper Mill Dryer Rolls. West Conshohocken, ASTM, 2001.

[46] ASTM A48/A48M-16: AMERICAN SOCIETY FOR TESTING AND MATERIALS Standard Specification for Gray Iron Castings, ASTM International, West Conshohocken, PA, 2016.

[47] ASTM E21-09: AMERICAN SOCIETY FOR TESTING AND MATERIALS - Standard Test Methods for Elevated Temperature Tension Testo of Metallic materials, ASTM International, West Conshohocken, PA, 2009, p. 1-8.

[48] ASTM E8/E8M-13: AMERICAN SOCIETY FOR TESTING AND MATERIALS Standard Test Methods for Tension Testing of Metallic Materials, ASTM International, West Conshohocken, PA, 2013, p. 1-28.

[49] ASTM E3-11: AMERICAN SOCIETY FOR TESTING AND MATERIALS - Standard Guide for Preparation of Metallographic Specimens, ASTM International, West Conshohocken, PA, 2011, p 1-12.

[50] SAE J1887/2002 (R2007): Automotive compacted Graphite Iron Castings. SAE International. 2007.

[51] ASTM A247-10: AMERICAN SOCIETY FOR TESTING AND MATERIALS Standard Test Method for Evaluating the Microstructure of Graphite in Iron Castings, 2010. 
[52] ASTM A842-11: AMERICAN SOCIETY FOR TESTING AND MATERIALS Standard Specification for Compacted Graphite Iron Castings, 2011.

[53] GILBERT, G. N. J. The Growth and Scaling Characteristics of Cast tons in Air and Steam. BCIRA J, v. 7, p. 478-566, 1959.

[54] ASTM E236 -17: AMERICAN SOCIETY FOR TESTING AND MATERIALS Standard Specification for Apparatus for Microdetermination of Alkoxyl Groups, 2017.

[55] LANGMAYR, F.; ZIEHER, D. F.; LAMPIC, M. Thermomechanik von Gusseisen für Zylinderköpfe. MTZ-Motortechnische Zeitschrift, v. 65, n. 4, p. 298-303, 2004. 